\title{
Western African Ebola virus epidemic
}

Ozzie Anis * et al.

\begin{abstract}
The Western African Ebola virus epidemic (2013-2016) was the most widespread outbreak of Ebola virus disease (EVD) in history-causing major loss of life and socioeconomic disruption in the region, mainly in the countries of Guinea, Liberia, and Sierra Leone. The first cases were recorded in Guinea in December 2013; later, the disease spread to neighboring Liberia and Sierra Leone, ${ }^{[1]}$ with minor outbreaks occurring elsewhere. It caused significant mortality, with the case fatality rate reported which was initially considerable, ${ }^{[1][2][3][\text { note } 1]}$ while the rate among hospitalized patients was $57-59 \%,[4]$ the final numbers 28,616 people, including 11,310 deaths, for a case-fatality rate of $40 \% .{ }^{[5]^{*}}$ Small outbreaks occurred in Nigeria and Mali, ${ }^{[6][7]^{*}}$ and isolated cases were recorded in Senegal, ${ }^{[8]}$ the United Kingdom and Italy. ${ }^{[3][9]}$ In addition, imported cases led to secondary infection of medical workers in the United States and Spain but did not spread further. ${ }^{[10] *[11]}$ The number of cases peaked in October 2014 and then began to decline gradually, following the commitment of substantial international resources. As of 8 May 2016, the World Health Organization (WHO) and respective governments reported a total of 28,616 suspected cases and 11,310 deaths $^{[12]}(39.5 \%)$, though the WHO believes that this substantially understates the magnitude of the outbreak. ${ }^{[13][14]^{*}}$

On 8 August 2014, a Public Health Emergency of International Concern was declared ${ }^{[15]}$ and on 29 March 2016, the WHO terminated the Public Health Emergency of International Concern status of the outbreak. ${ }^{[16][17][18]}$ Subsequent flare-ups occurred; the last was declared over on 9 June 2016, 42 days after the last case tested negative on 28 April 2016 in Monrovia. ${ }^{[19]}$

The outbreak left about 17,000 survivors of the disease, many of whom report post-recovery symptoms termed post-Ebola syndrome, often severe enough to require medical care for months or even years. An additional cause for concern is the apparent ability of the virus to "hide" in a recovered survivor's body for an extended period of time and then become active months or years later, either in the same individual or in a sexual partner..$^{[20]^{*}} \ln$ December 2016, the WHO announced that a two-year trial of the rVSV-ZEBOV vaccine appeared to offer protection from the variant of EBOV responsible for the Western Africa outbreak. The vaccine has not yet been given regulatory approval, but it is considered to be effective and is the only prophylactic which offers protection hence 300,000 doses have been stockpiled. ${ }^{[21][22]^{*}}$
\end{abstract}

Note: Due to the nature of the subject, many citations are drawn from contemporary media reports as sources and have been marked with an *.

\section{Overview}

Ebola virus disease (commonly known as "Ebola") was first described in 1976 in two simultaneous outbreaks in the Democratic Republic of the Congo and what is now South Sudan. ${ }^{[23]}$ The 2013-2016 outbreak, caused by Ebola virus (EBOV) ${ }^{[24]}$ the first anywhere in the world to reach epidemic proportions. Previous outbreaks had been brought under control in a much shorter period of time. Extreme poverty, dysfunctional healthcare systems, distrust of government after years of armed conflict, and the delay in responding for several months, all

*Author correspondence: by online form

ORCID: 0000-0002-4061-2429

Licensed under: CC-BY-SA

Received 30-10-2018; accepted 11-05-2019 contributed to the failure to control the epidemic. Other factors, per media reports, included local burial customs of washing the body and the unprecedented spread of Ebola to densely populated cities. ${ }^{[25][26] *[27][28] *[29] *}$

As the outbreak progressed, the media reports, many hospitals, short on both staff and supplies, were overwhelmed and closed down, leading some health experts to state that the inability to treat other medical needs may have been causing "an additional death toll

[note 1] The mortality (number of dead per number of healthy per time frame) recorded in Liberia up to 26 August 2014 was $70 \%{ }^{[2]}$ However, due to the estimation method used, the estimated case fatality rate $(70.8 \%)$ for this particular epidemic differs from the actual ratio between the number of deaths and the number of cases. 


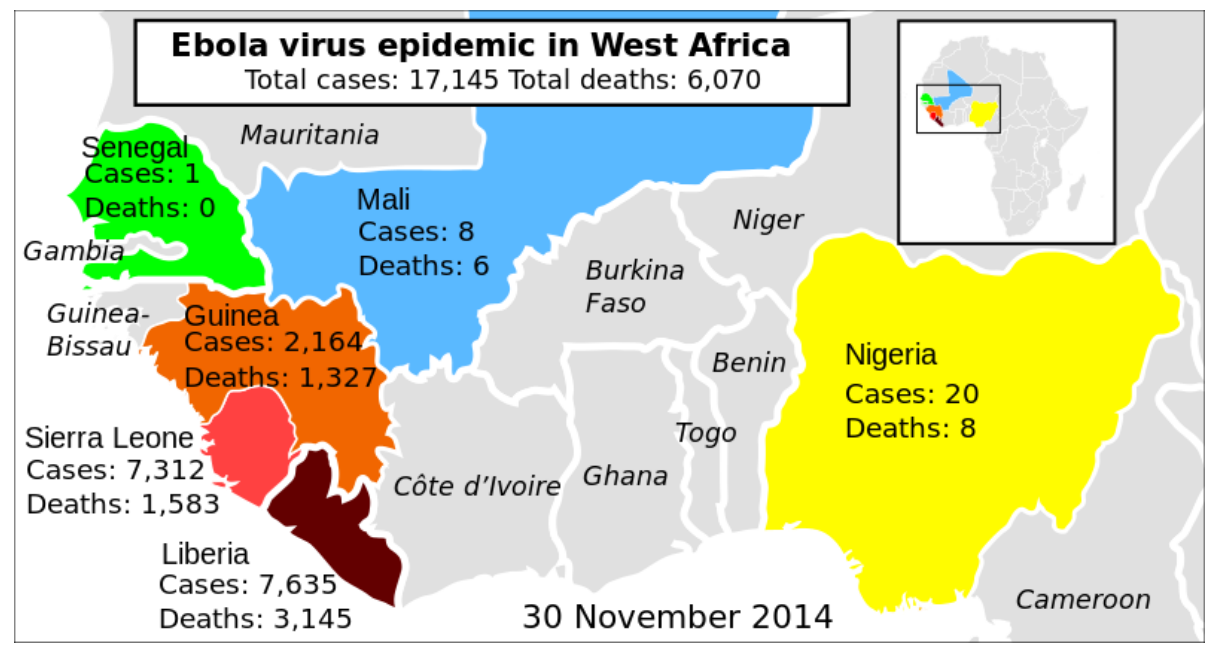

Figure 1 | Map showing death statistics as of 2014. Mikael Häggström, Public Domain

consequences in both the affected areas in Western Africa and even in other African nations with no cases of Ebola. ${ }^{[38]}$

On 28 January 2015, the $\mathrm{WHO}$ reported that for the first time since the week ending 29 June 2014, there had been fewer than 100 new confirmed cases reported in a week in the three most-affected countries. The response to the epidemic then moved to a second phase, as the focus shifted from slowing trans-

[that is] likely to exceed that of the outbreak itself". ${ }^{[30] *[31] *}$ Hospital workers, who worked closely with the highly contagious body fluids of the victims, were especially vulnerable to contracting the virus; in August 2014 , the WHO reported that ten percent of the dead had been healthcare workers. ${ }^{[32]}$ In September 2014, it was estimated that the affected countries' capacity for treating Ebola patients was insufficient by the equivalent of 2,122 beds; however, by December 2014 there were enough beds to treat and isolate all reported cases, although the uneven distribution of cases was resulting in serious shortfalls in some areas. ${ }^{[3]}$

The WHO has been widely criticised for its delay in taking action to address the epidemic. ${ }^{[34]^{*}}$ On 8 August 2014, it declared the outbreak a public health emergency of international concern. ${ }^{[35]}$ By September 2014, Médecins Sans Frontières/Doctors Without Borders (MSF), the non-governmental organization with the largest working presence in the affected countries, had grown increasingly critical of the international response. Speaking on 3 September, the International President of MSF spoke out concerning the lack of assistance from United Nations (UN) member countries: "Six months into the worst Ebola epidemic in history, the world is losing the battle to contain it."[36]* In a 26 September statement, the WHO stated that "[t]he Ebola epidemic ravaging parts of Western Africa is the most severe acute public health emergency seen in modern times" and its Director-General called the outbreak "the largest, most complex and most severe we've ever seen". ${ }^{[37]}$ In March 2015, the United Nations Development Group reported that due to a decrease in trade, closing of borders, flight cancellations, and drop in foreign investment and tourism activity fuelled by stigma, the epidemic had resulted in vast economic mission to ending the epidemic. ${ }^{[39]}$ On 8 April 2015, the WHO reported a total of only 30 confirmed cases, ${ }^{[40]}$ and the weekly update for 29 July reported only seven new cases. ${ }^{[41]}$ Cases continued to gradually dwindle and on 7 October 2015, all three of the most seriously affected countries, per media reports, recorded their first joint week without any new cases. ${ }^{[42]}$ However, as of late 2015, while the large-scale epidemic had ended, according to media reports, sporadic new cases were still being recorded, frustrating hopes that the epidemic could be declared over. ${ }^{[43]^{*}}$

On 31 July 2015, the WHO announced "an extremely promising development" in the search for an effective vaccine for Ebola virus disease. While the vaccine had shown high efficacy in individuals, more conclusive evidence was needed regarding its capacity to protect populations through herd immunity. ${ }^{[44][45]}$ In August 2015, after substantial progress in reducing the scale of the epidemic, the WHO held a meeting to work out a "Comprehensive care plan for Ebola survivors" and identify research needed to optimize clinical care and social well-being. Stating that "the Ebola outbreak has decimated families, health systems, economies, and social structures", the WHO called the aftermath of the epidemic "an emergency within an emergency." Of special concern is recent research that shows some Ebola survivors experience a so-called "post-Ebola Syndrome", with symptoms so severe that survivors may require medical care for months and even years. ${ }^{[46][47]}$ As the main epidemic was coming to an end in December 2015, the UN announced that 22,000 children had lost one or both parents to Ebola. ${ }^{[48]^{*}}$ On 29 March 2016, the Director-General of WHO terminated the Public Health Emergency of International Concern status of the Western African Ebola virus epidemic. ${ }^{[16]}$ 


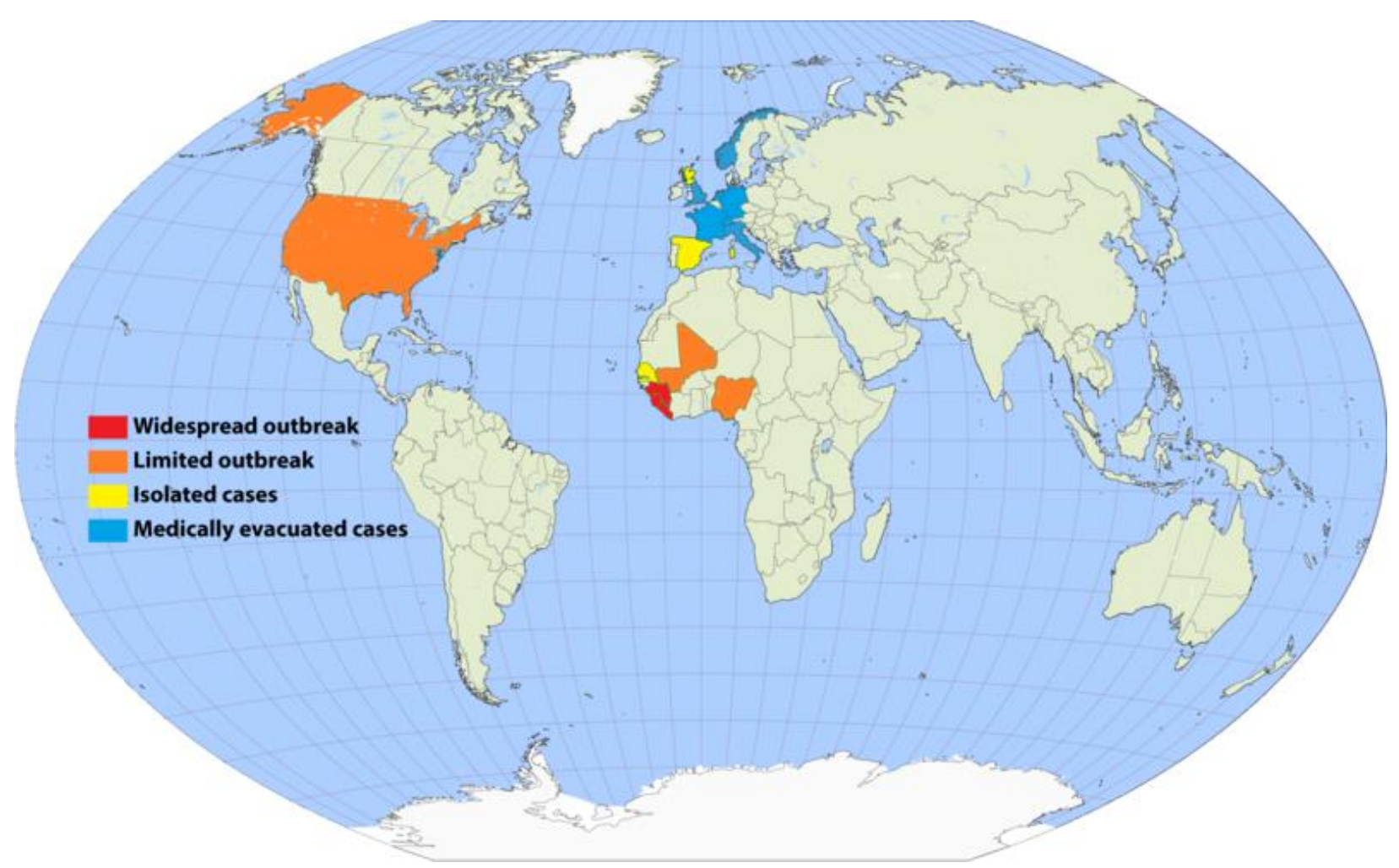

Figure 2 | Ebola outbreak worldwide. Раціональне анархіст, GNU Free Documentation License

\section{Epidemiology}

\section{Outbreak}

See also: Ebola virus epidemic in West Africa timeline

It was generally believe that a one-year-old boy, ${ }^{[49] *}$ later identified as Emile Ouamouno, who died in December 2013 in the village of Méliandou, Guéckédou Prefecture, Guinea, was the index case of the Western African epidemic. ${ }^{[50]}$ Scientists have deduced that bats are involved in the spread of the virus ${ }^{[51]^{*}}$, and, incidentally, the boy's home was in the vicinity of a large colony of Angolan free-tailed bats, according to media reports ${ }^{[52]^{*}}$ His mother, sister, and grandmother, per media reports later became ill with similar symptoms and also died; people infected by these initial cases spread the disease to other villages. ${ }^{[53]^{*}[54]^{*}}$ There was knowledge of Tai Forest virus in Côte d'Ivoire, which had resulted in one human transmission in 1994. Thus, these early cases were diagnosed as other conditions more common to the area and the disease had several months to spread before it became recognized as Ebola. ${ }^{[50][53]^{*}}$

On 25 March 2014, the WHO indicated that Guinea's Ministry of Health had reported an outbreak of Ebola virus disease in four south eastern districts, and that suspected cases in the neighbouring countries of Liberia and Sierra Leone were being investigated. In Guinea, a total of 86 suspected cases, including 59 deaths, had been reported as of 24 March. ${ }^{[5]}$ By late May, the outbreak had spread to Conakry, Guinea's capital-a city of about two million people. ${ }^{[55]}$ On 28 May, the total number of reported cases had reached 281, with 186 deaths. ${ }^{[55]}$

In Liberia, the disease was reported in four counties by mid-April 2014 and cases in Liberia's capital Monrovia were reported in mid-June. ${ }^{[56]}$ The outbreak then spread to Sierra Leone and progressed rapidly. By 17 July, the total number of suspected cases in the country stood at 442, surpassing those in Guinea and Liberia. ${ }^{[57]}$ By 20 July, additional cases of the disease had been reported by the media in the Bo District, while the first case in Freetown, Sierra Leone's capital, was reported in late July. ${ }^{[58] *[59] *}$

As the epidemic progressed, a small outbreak occurred in Nigeria that resulted in 20 cases and another in Mali with 7 cases. Four other countries (Senegal, Spain, the United Kingdom and the United States of America) also reported cases imported from Western Africa, with widespread and intense transmission. ${ }^{[60][6]][62]}$

On 31 March 2015, one year after the first report of the outbreak, the total number of cases was in excess of 25,000 - with over 10,000 deaths. ${ }^{[63]}$ 
As the epidemic waned, following international control efforts, the edition of 8 April 2015 of the WHO's Ebola Situation Reports stated that a total of 30 cases were reported ${ }^{[64]}$ and in 29 July 2015, the WHO weekly update reported only 7 cases-the lowest in more than a year. ${ }^{[41]}$ In October 2015, the WHO recorded its first week without any new cases, ${ }^{[42]}$ and while the largescale epidemic appeared to have ended by late 2015 , sporadic new cases continued to be reported. ${ }^{[4] * *[65]}$

On 14 January 2016, after all the previously infected countries had been declared Ebola-free, the WHO reported that "all known chains of transmission have been stopped in Western Africa", but cautioned that further

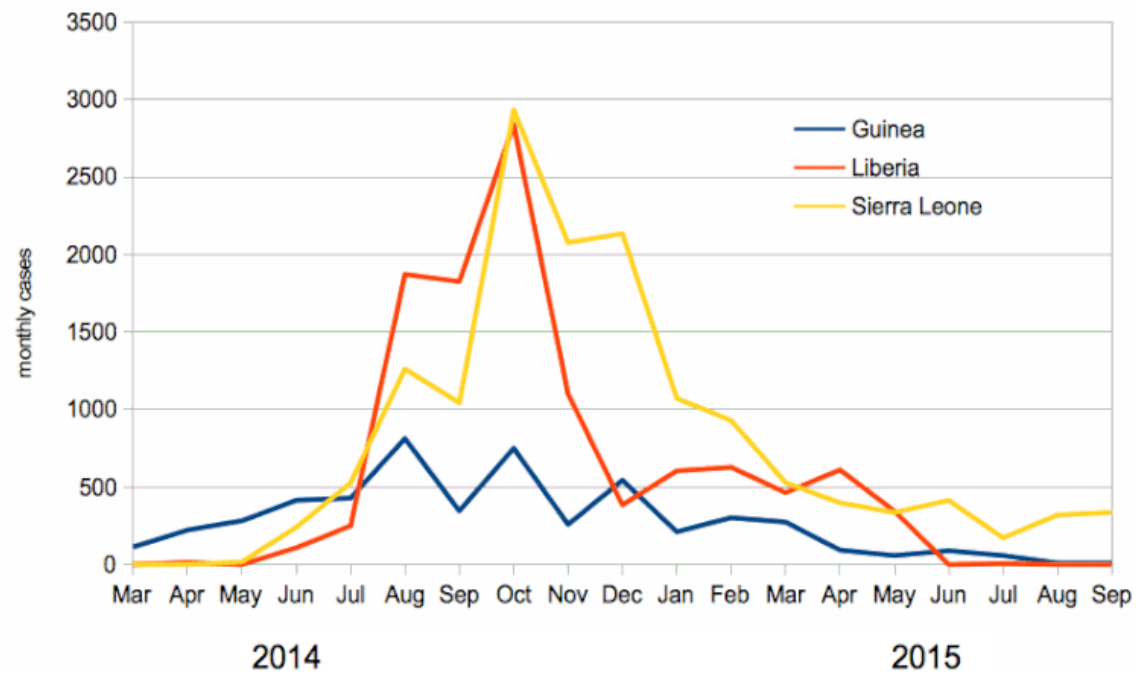

Figure 4 | Monthly aggregate Ebola cases in the Western Africa epidemic 2014-15 Chris Moss, CC BY-SA 4.0

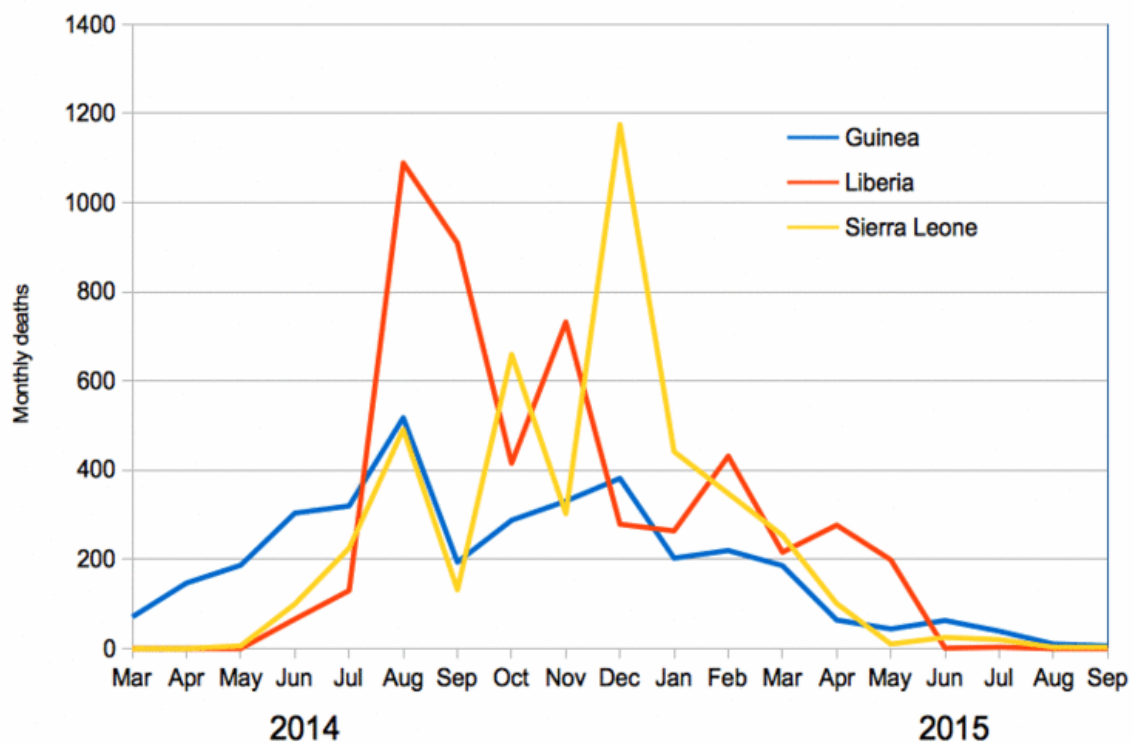

Figure 4 | Monthly aggregate Ebola deaths in the Western Africa epidemic 2014-15 . Chris Moss, CC BY-SA 4.0 small outbreaks of the disease could occur in the future. ${ }^{[6]]^{*}}$ The following day, Sierra Leone confirmed its first new case since September 2015. ${ }^{[18]}$

\section{Countries that experienced widespread transmission}

\section{Guinea}

Further information: Ebola virus epidemic in Guinea

On 25 March 2014, the WHO reported an outbreak of Ebola virus disease in four south eastern districts of Guinea with a total of 86 suspected cases, including 59 deaths, and MSF assisted the Ministry of Health by establishing Ebola treatment centers in the epicenter of the outbreak. ${ }^{[55]}$ On 31 March, the U.S. Centers for Disease Control and Prevention (CDC) sent a fiveperson team to assist in the response to the outbreak. ${ }^{[55]}$ Thinking that spread of the virus had been contained, MSF closed its treatment centers in May, leaving only a skeleton staff to handle the Macenta region. However, in late August, according to media reports, large numbers of new cases reappeared in the region. ${ }^{[67]^{*}}$

In February 2015, media reported that, Guinea recorded a rise in cases for the second week in a row, ${ }^{[68]}$ health authorities stated that this was related to the fact that they "were only now gaining access to faraway villages", where violence had previously prevented them from entering. ${ }^{[69]}$ On 14 February, violence erupted and an Ebola treatment center near the center of the country was destroyed. Guinean Red Cross teams said they had suffered an average of 10 attacks a month over the previous year; ${ }^{[70]^{*}}$ MSF reported that acceptance of Ebola education remained low and that further violence against their workers might force them to leave. ${ }^{[71]}$ 


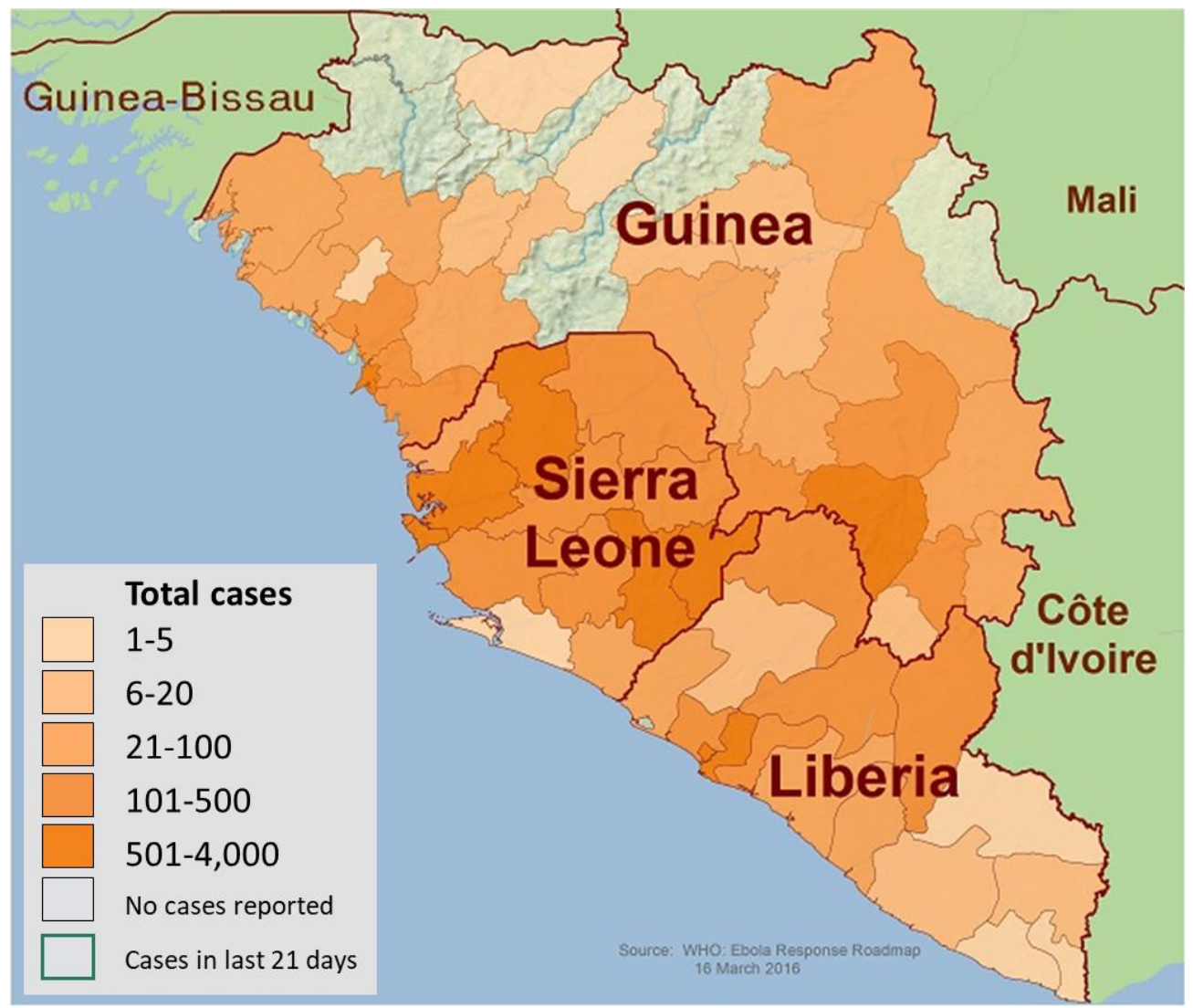

Figure 5 | Outbreak distribution map affected part of Western Africa (17 December 2014). $C D C$, public domain
Resistance to interventions by health officials among the Guinean population remained greater than in Sierra Leone and Liberia, per media reports, raising concerns over its impact on ongoing efforts to halt the epidemic; in mid-March, there were 95 new cases and on 28 March, and a 45-day "health emergency" was declared in 5 regions of the country ${ }^{[71][72]}$ On 22 May, the WHO reported another rise in cases, per media reports, ${ }^{[73]}$ which was believed to have been due to funeral transmissions $i^{[74]^{*}}$ on 25 May, six persons were placed in prison isolation after they were found travelling with the corpse of an individual who had died of the disease, ${ }^{[75]}$ on 1 June, it was reported that violent protests in a north Guinean town at the border with Guinea-Bissau had caused the Red Cross to withdraw its workers. ${ }^{[76]}$

In late June 2015, the WHO reported that "weekly case incidence has stalled at between 20 and 27 cases since the end of May, whilst cases continue to arise from unknown sources of infection, and to be detected only after post-mortem testing of community deaths". ${ }^{[77]}$ On 29 July, a sharp decline in cases was reported, ${ }^{[41]}$ with only a single case, per media reports left by the end of the week, ${ }^{\left[{ }^{[78]}\right.}$ the number of cases eventually plateaued at 1 or 2 cases per week after the beginning of August. ${ }^{[79]}$ On 28 October, an additional 3 cases were reported in the Forécariah Prefecture by the WHO. ${ }^{[80]} \mathrm{On}$
6 November, a media report indicated Tana village to be the last known place with Ebola in the country, ${ }^{[81]^{*}}$ and on 11 November, WHO indicated that no Ebola cases were reported in Guinea; this was the first time since the epidemic began, that no cases had been reported in any country ${ }^{[82]}$. On 15 November, the last quarantined individuals were released, per media reports ${ }^{[83]}$ and on 17 November, the last Ebola patient in Guinea-a 3-week-old baby-had recovered; the 42day countdown toward the country being declared Ebola-free started on 17 November, the day after the patient yielded a second consecutive negative blood test. ${ }^{[84][85][86]}$ The patient was discharged from the hospital on 28 November, per media reports ${ }^{[87]}$ on 29 December 2015, upon expiration of the 42-day waiting period, the WHO declared Guinea Ebola-free. ${ }^{[8]^{*}}$

On 17 March 2016, the government of Guinea reported, per the media, that 2 people had again tested positive for Ebola virus in Korokpara, ${ }^{[89]}$ it was also reported that they were from the village where members of one family had recently died from vomiting (and diarrhea). ${ }^{[90] *}$ On 19 March, it was also reported by the media that another individual had died due to the virus at the treatment centre in Nzerekore, ${ }^{[91]}$ consequently, the country's government quarantined an area around the home where the cases took place. ${ }^{[92]}$ On 22 March, the media 
reported that medical authorities in Guinea had quarantined 816 suspected contacts of the prior cases (more than 100 individuals were considered high-risk); ${ }^{\text {[93][94] }}$ the same day, Liberia ordered its border with Guinea closed. ${ }^{[95]}$ Macenta Prefecture, 200 kilometers from Korokpara, registered Guinea's fifth fatality due to Ebola virus disease within the same period. ${ }^{[96] *}$ On 29 March, it was reported that about 1,000 contacts had been identified (142 of them high-risk), ${ }^{[16]}$ and on 30 March 3 more confirmed cases were reported from the sub-prefecture of Koropara. ${ }^{[97]}$ On 1 April, it was reported by the media, that possible contacts, which numbered in the hundreds, had been vaccinated with an experimental vaccine using a ring vaccination approach. ${ }^{[98][99]}$

On 5 April 2016, it was reported via the media, that there had been 9 new cases of Ebola since the virus resurfaced, out of which 8 were fatal; ${ }^{[100]^{*}}$ on 1 June, after the stipulated waiting period, the WHO again declared Guinea Ebola-free, ${ }^{[101]^{*}}$ after which the country entered a 90-day period of heightened surveillance that was concluded on 30 August 2016.

In September 2016, findings were published suggesting that the resurgence in Guinea was caused by an Ebola survivor who, after eight months of abstinence, had sexual relations with several partners, including the first victim in the new outbreak. ${ }^{[102][103]}$ The disease was also spread to Liberia by a woman who went there after her husband had died of Ebola. ${ }^{[104]}$

\section{Sierra Leone}

Further information: Ebola virus epidemic in Sierra Leone

The first person reported infected, per media reports, in Sierra Leone was a tribal healer who had been treating Ebola patients from across the nearby border with

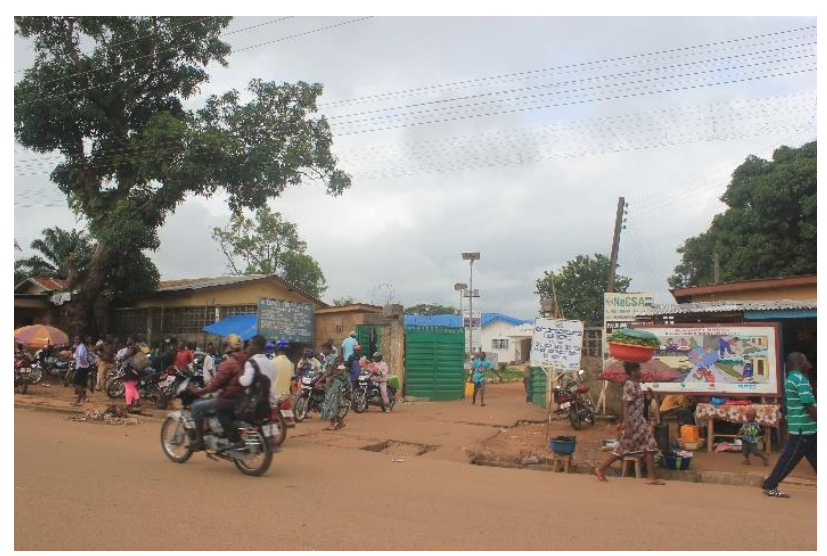

Figure 7 | Kenema Hospital, Sierra Leone.

Anne Kennedy, CC BY-SA 3.0
Guinea and died on 26 May 2014; according to tribal tradition, her body was washed for burial and this appears to have led to infections in women from neighbouring towns. ${ }^{[105]^{*}}$ On 11 June, Sierra Leone shut its borders for trade with Guinea and Liberia and closed some schools in an attempt to slow the spread of the virus; ${ }_{i}^{[106]^{*}}$ on 30 July, the government began to deploy troops to enforce quarantines, ${ }^{[107]^{*}}$ and by 15 October, the last district in Sierra Leone untouched by the disease had declared Ebola cases. ${ }^{[108]^{*}}$

During the first week of November, it was reported that the situation was "getting worse" due to intense transmission in Freetown. According to the Disaster Emergency Committee, food shortages resulting from aggressive quarantines were making the situation worse, ${ }^{[109]}$ and on 4 November, it was reported by media that thousands had violated quarantine in search of food in the town of Kenema. ${ }^{[110]}$ With the number of cases continuing to increase, an MSF coordinator described the situation in Sierra Leone as "catastrophic", saying, "there are several villages and communities that have been basically wiped out ... Whole communities have disappeared but many of them are not in the statistics." ${ }^{[111]}$ In mid-November, the WHO reported that, while there was some evidence that the number of cases were no longer rising in Guinea and Liberia, steep increases persisted in Sierra Leone. ${ }^{[60]}$

On 9 December 2014, news reports described the discovery of "a grim scene"-piles of bodies, overwhelmed medical personnel and exhausted burial teams-in the remote eastern Kono District. ${ }^{[112]}$ On 15 December, the CDC indicated that their main concern was Sierra Leone, where the epidemic had shown no signs of abating as cases continued to rise exponentially; by the second week of December, Sierra Leone had reported nearly 400 cases - more than three times the number reported by Guinea and Liberia combined. According to the CDC,

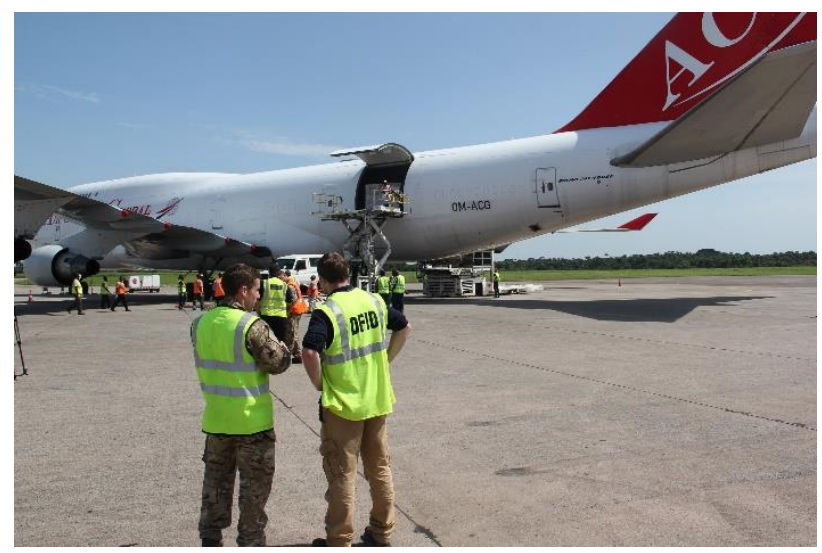

Figure 7 | Ebola crisis: More UK aid arrives in Sierra Leone. DFID, CC BY 2.0 
"the risk we face now [is] that Ebola will simmer along, become native and be a problem for Africa and the world, for years to come."[113] On 17 December, President Koroma launched "Operation Western Area Surge" and workers went door-to-door in the capital city looking for possible cases. ${ }^{[114][115]}$ The operation led to a surge in the number of cases, with 403 new ones reported between 14 and 17 December. ${ }^{[114][116]}$

According to the 21 January 2015 WHO Situation Report, the case incidence was rapidly decreasing in Sierra Leone. ${ }^{[117] *[118][119]}$ However, in February and March, it was reported that there was again a rise in the number of cases. ${ }^{[120] *[121][122][123]}$ The following month, the 5 April WHO report again disclosed a downward trend ${ }^{[124]}$ and the WHO weekly update for 29 July reported a total of only 3 new cases, the lowest in more than a year. ${ }^{[41]}$ On 17 August, the country had its first week with no new cases, ${ }^{[125] *}$ and one week later the last patients were released. ${ }^{[126]}$ However, a new case was reported on 1 September, when a patient from Sella Kafta village in Kambia District tested positive for the disease after her death; ${ }^{[127]^{*}}$ hers eventually resulted in 3 other cases from among her contacts. ${ }^{[128]^{*}}$

On 14 September 2015, Sierra Leone's National Ebola Response Center confirmed the death of a 16-year-old in a village in the Bombali District. ${ }^{[129]^{*}}$ It is suspected that she contracted the disease from the semen of an Ebola survivor who had been discharged in March 2015. ${ }^{[130]^{*}}$ On 27 September, a new 42-day countdown began to declare the country Ebola-free, ${ }^{[131]}$ which eventually occurred on 7 November 2015, thereafter, the country increased its vigilance on the Guinean border. $^{[132][133]}$

Sierra Leone had entered a 90-day period of enhanced surveillance that was scheduled to end on 5 February 2016, when, on 14 January, a new Ebola death was reported in the Tonkolili District. ${ }^{[134][135]}$ Prior to this case, the WHO had advised that "we still anticipate more flare-ups and must be prepared for them. A massive effort is underway to ensure robust prevention, surveillance and response capacity across all three countries by the end of March."[136] On 16 January, aid workers reported that a woman had died of the virus and that she may have exposed several individuals; the government later announced that 100 people had been quarantined. ${ }^{[137]}$ Investigations indicated that the deceased was a female student from Lunsar, in Port Loko District who had gone to Kambia District on 28 December 2015 before returning symptomatic. She had also visited Bombali District to consult a herbalist, and had later gone to a government hospital in Magburaka. The WHO indicated that there were 109 contacts (28 of them high-risk), that there were another 3 missing contacts, and that the source or route of transmission that caused the fatality was unknown. ${ }^{[138]}$ A second new case-confirmed by WHO spokesman Tarik Jasarevic to be a 38-year-old relative and caregiver of the aforementioned Ebola victim -had become symptomatic on 20 Jan while under observation at a quarantine centre. ${ }^{[139] *[140]}$ On 22 January, it was reported that this patient was responding to treatment. ${ }^{[141]}$ On 26 January, WHO Director-General, Dr Margaret Chan officially confirmed that the outbreak was not yet over; ${ }^{[18]}$ that same day, it was also reported that Ebola restrictions had halted market activity in Kambia District, amid protests. $^{[142]}$ On 7 February 70 individuals were released from quarantine, ${ }^{[143]}$ and on 8 February the last Ebola patient was also released. ${ }^{[144]}$ On 17 February, the WHO indicated that 2,600 Ebola survivors had accessed health assessments and eye examinations. ${ }^{[145]}$

On 4 February 2016, the last known case tested negative for a second consecutive time and Sierra Leone commenced a second 42-day countdown towards being declared Ebola-free. ${ }^{[146][147]}$ On 17 March 2016, the WHO announced that the Sierra Leone flare-up was over, and that no other chains of transmission were known to be active at that time. ${ }^{[148]}$ The media reported that Sierra Leone then entered a 90-day period of heightened surveillance, which was concluded on 15 June 2016, and it was reported that by 15 July, the country had discontinued testing corpses for the virus. ${ }^{[149]}$

\section{Liberia}

Further information: Ebola virus epidemic in Liberia

In Liberia, the disease was reported in both Lofa and Nimba counties in late March 2014. ${ }^{[150]^{*}}$ On 27 July, President Ellen Johnson Sirleaf announced that Liberia would close its borders, with the exception of a few crossing points such as the airport, where screening centres would be established. ${ }^{[151]^{*}}$ Schools and universities were closed, ${ }^{[152]^{*}[153]^{*}}$ and the worst-affected areas in the country were placed under quarantine..$^{[154]^{*}}$

With only 50 physicians in the entire country-one for every 70,000 citizens-Liberia was already in a healthcare crisis. ${ }^{[155]^{*}}$ In September, the CDC reported that some hospitals had been abandoned, while those still functioning lacked basic facilities and supplies. ${ }^{[156]}$ In October, the Liberian ambassador in Washington was reported as saying that he feared that his country may be "close to collapse", ${ }^{[155]^{*}}$ by 24 October, all of the 15 Liberian districts had reported Ebola cases. ${ }^{[157] *[158]}$

By November 2014, the rate of new infections in Liberia appeared to be declining and the state of emergency 


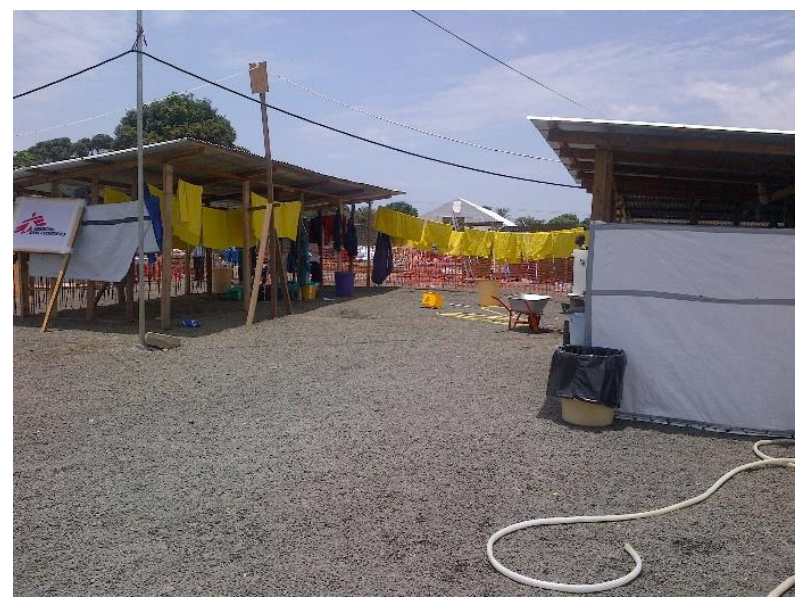

Figure 8 | An Ebola treatment unit in Liberia. CDC global, CC BY 2.0

was lifted. The drop in cases was believed to be related to an integrated strategy combining isolation and treatment with community behaviour change, including safe burial practices, case finding and contact tracing. ${ }^{[159] *[160] *}$

In January 2015, the MSF field coordinator reported that Liberia was down to only 5 confirmed cases. ${ }^{[161]}$ In March, after two weeks of not reporting any new cases, 3 new cases were confirmed. ${ }^{[162]}$ On 8 April, a new health minister was named in an effort to end Ebola in the country and on 26 April, MSF handed the Ebola treatment facility, ELWA-3, over to the government. ${ }^{[163]}$ On 30 April, the US shut down a special Ebola treatment unit in Liberia. ${ }^{[164]}$ The last known case of Ebola died on $27 \mathrm{March}^{[165]}$ and the country was officially declared Ebola-free on 9 May 2015, after 42 days without any further cases being recorded. The WHO congratulated Liberia saying, "reaching this milestone is a testament to the strong leadership and coordination of Liberian President Ellen Johnson Sirleaf and the Liberian Government, the determination and vigilance of Liberian communities, the extensive support of global partners, and the tireless and heroic work of local and international health teams." [166] As at May 2015, the country remained on high alert against recurrence of the dis-

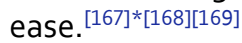

After three months with no new reports of cases, on 29 June Liberia reported that the body of a 17-year-old boy, who had been treated for malaria, tested positive for Ebola. The WHO said the boy had been in close contact with at least 200 people, ${ }^{[170]^{*}}$ who they were following up, and that "the case reportedly had no recent history of travel, contact with visitors from affected areas, or funeral attendance." A second case was confirmed on 1 July. ${ }^{[171][172]}$ After a third new case was confirmed on 2 July, and it was discovered that all 3 new cases had shared a meal of dog meat, researchers looked at the possibility that the meat may have been involved in the transfer of the virus. ${ }^{[173] *[174]}$ Testing of the dog's remains, however, was negative for the Ebola virus. ${ }^{[175]} \mathrm{By}$ 9 July 3 more cases were discovered, bringing the total number of new cases to 5 , all from the same area. ${ }^{[176]}$ On 14 July, a woman died of the disease in the county of Montserrado, bringing the total to $6 .^{[177]^{*}}$ On 20 July, the last patients were discharged, ${ }^{[178]}$ and on 3 September 2015, Liberia was declared Ebola-free again. ${ }^{[179]}$

After two months of being Ebola-free, a new case was confirmed on 20 November 2015, when a 15-year-old boy was diagnosed with the virus ${ }^{[180][181]}$ and two family members subsequently tested positive as well. ${ }^{[182][183]}$ Health officials were concerned because the child had not recently travelled or been exposed to someone with Ebola and the WHO stated that "we believe that this is probably again, somehow, someone who has come in contact with a virus that had been persisting in an individual, who had suffered the disease months ago." Two staff of the CDC were sent to the country to help ascertain the cause of the new cases. ${ }^{[184]^{*}}$ The infected boy died on 24 November, ${ }^{[185]}$ and on 3 December 2 remaining cases were released after recovering from the disease. ${ }^{[186]}$ The 42-day countdown toward Liberia being declared Ebola-free, for the third time, started on $4 \mathrm{De}$ cember 2015. ${ }^{[187]}$ On 16 December, the WHO reaffirmed that the cases in Liberia were the result of reemergence of the virus in a previously infected person, ${ }^{[188]}$ and there was speculation that the boy may have been infected by an individual who became infectious once more due to pregnancy, which may have weakened her immune system. ${ }^{[189]}$ On 18 December, the WHO indicated that it still considered Ebola in Western Africa a public health emergency, though progress had been made. ${ }^{[190]}$

After having completed the 42-day time period, Liberia was declared free from the virus on 14 January 2016, effectively ending the outbreak that had started in neighbouring Guinea 2 years earlier. Liberia began a 90-day period of heightened surveillance, scheduled to conclude on 13 April 2016, ${ }^{[191]^{*}}$ but on 1 April, it was reported that a new Ebola fatality had occurred, ${ }^{[192]}$ and on 3 April, a second case was reported in Monrovia. ${ }^{[193]}$ On 4 April, it was reported that 84 individuals were under observation due to contact with the 2 confirmed Ebola cases. ${ }^{[194]}$ By 7 April, Liberia had confirmed 3 new cases since the virus resurfaced and a total of 97 contacts, including 15 healthcare workers, were being monitored. ${ }^{[195]^{*}}$ The index case of the new flareup was reported to be the wife of a patient who died from Ebola in Guinea; she had traveled to Monrovia after the funeral but succumbed to the disease. ${ }^{[196]}$ The outbreak in 
Guinea, in turn, had begun when a man, who had survived Ebola, had sexual intercourse with a woman and passed the virus to her, even though he had recovered more than a year earlier. ${ }^{[102][103]}$

On 29 April, WHO reported that Liberia had discharged the last patient and had begun the 42-day countdown to be declared Ebola-free once more. According to the $\mathrm{WHO}$, tests indicated that the flare-up was likely due to contact with a prior Ebola survivor's infected body fluids. ${ }^{[104]}$ On 9 June, the flare up was declared over, and the country Ebola-free, due to the passage of the 42day period; ${ }^{[197] *[198]}$ Liberia then entered a 90 -day period of heightened surveillance, which ended on 7 September 2016. In early July 2016, a trial for males with detectable Ebola RNA in semen, started. ${ }^{[199]}$

\section{Western African countries with limited local cases}

\section{Senegal}

In March 2014, the Senegal Ministry of Interior closed its southern border with Guinea, ${ }^{[200] *}$ but on 29 August, the health minister announced the country's first case a university student from Guinea who was being treated in a Dakar hospital. ${ }^{[201]}$ The patient was a native of Guinea who had traveled to Dakar, arriving on $20 \mathrm{Au}$ gust. On 23 August, he sought medical care for symptoms including diarrhoea, and vomiting plus signs of fever. He received treatment for malaria, but did not improve and left the facility. Still experiencing the same symptoms, on 26 August he was referred to a specialized facility for infectious diseases, and subsequently hospitalized. ${ }^{[201]}$

On 28 August 2014, authorities in Guinea issued an alert informing their medical services and neighbouring countries that a person who had been in close contact with an Ebola-infected patient had escaped their surveillance system. The alert prompted testing for Ebola at the Dakar laboratory, and the positive result launched an investigation, triggering urgent contact tracing. ${ }^{[201]}$ On 10 September, it was reported that the student had recovered but health officials continued to monitor his contacts for 21 days. ${ }^{[202]}$ No further cases were reported, ${ }^{[203]}$ and on 17 October 2014, the WHO officially declared that the outbreak in Senegal had ended. ${ }^{[157]}$

The WHO officially commended the Senegalese government, and in particular the President Macky Sall and the Minister of Health, Dr Awa Coll-Seck, for their response in quickly isolating the patient and tracing and following up 74 contacts, as well as for their public awareness campaign. This acknowledgement was also extended to MSF and the CDC for their assistance. ${ }^{[204]}$

\section{Nigeria}

Further information: Ebola virus disease in Nigeria

The first case in Nigeria was a Liberian-American, who flew from Liberia to Nigeria's most populated city of Lagos on 20 July 2014. On 6 August 2014, the Nigerian health minister told reporters that one of the nurses that attended to the Liberian had died from the disease. 5 newly confirmed cases were being treated at an isolation ward. ${ }^{[205] *}$

On 22 September 2014, the Nigerian health ministry announced, "As of today, there is no case of Ebola in Nigeria." According to the WHO, 20 cases and 8 deaths were confirmed, including the imported case, who also died. 4 of the dead were health workers who had cared for the index case. ${ }^{[206] *}$

The WHO's representative in Nigeria officially declared the country Ebola-free on 20 October 2014, after no new active cases were reported in the follow up contacts, stating it was a "spectacular success story". ${ }^{[207]} \mathrm{Ni}$ geria was the first African country to be declared Ebola free. ${ }^{[208]}$

\section{Mali}

Further information: Ebola virus disease in Mali

On 23 October 2014, the first case of Ebola virus disease in Mali was confirmed in the city of Kayes-a two-yearold girl who had arrived with a family group from Guinea, and died the next day. ${ }^{[209][210]}$ Her father had worked for the Red Cross in Guinea and also in a private health clinic; he had died earlier in the month, likely from an Ebola infection contracted in the private clinic. It was later established that a number of family members had also died of Ebola. The family had returned to Mali after the father's funeral via public bus and taxi-a journey of more than 1,200 kilometres $(750 \mathrm{mi})$. All contacts were followed for 21 days, with no further spread of the disease reported. ${ }^{[211]}$

On 12 November 2014, Mali reported deaths from Ebola in an outbreak unconnected with the first case in Kayes. The first probable case was an imam who had fallen ill on 17 October in Guinea and was transferred to the Pasteur Clinic in Mali's capital city, Bamako, for treatment. He was treated for kidney failure but was not tested for Ebola; he died on 27 October and his body returned to Guinea for burial. ${ }^{[212]}$ A nurse and a doctor who had treated the imam subsequently fell ill with Ebola and died. ${ }^{[213]^{*}[214]^{*}}$ The next 3 cases were related 


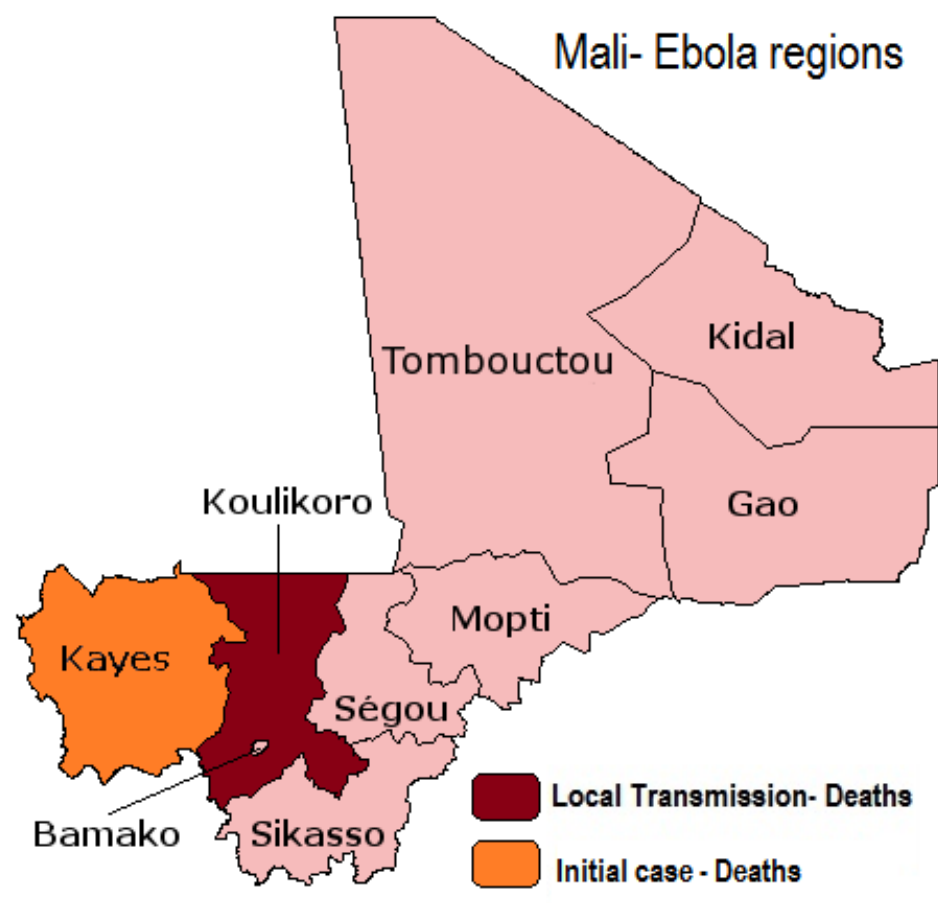

Figure 9 | Malian regions with Ebola cases (Kayes/Bamako), November 2014. Brian Groen, CC BY 3.0

to the imam as well: a man who had visited the imam while he was in hospital, his wife and his son. On 22 November, the final case related to the imam was reported-a friend of the Pasteur Clinic nurse who had died from the Ebola virus. ${ }^{[215]^{*}}$ On 12 December, the last case in treatment recovered and was discharged, "so there are no more people sick with Ebola in Mali", according to a Ministry of Health source. ${ }^{[216]}$ On 16 December, Mali released the final 13 individuals who were being quarantined ${ }^{[217]}$ and 24 days later (18 January 2015) without new cases, the country was declared Ebola-free. ${ }^{[6]}$

\section{Other countries with limited local cases}

\section{United Kingdom}

Further information: Ebola virus disease in the United Kingdom

On 29 December 2014, Pauline Cafferkey, a British aid worker who had just returned to Glasgow from Sierra Leone, was diagnosed with Ebola. ${ }^{[218] *}$ She was treated and declared to be free of infection and released from hospital on 24 January 2015..$^{219][220]^{*}}$ On 8 October, she was readmitted for complications caused by the virus $^{[221]}$ and was in "serious" condition, according to a hospital report. On 14 October, her condition was listed as "critical"[222]* and 58 individuals were being monitored and 25 received an experimental vaccination, be- ing close contacts. ${ }^{[223][224]}$ On 21 October, it was reported that she had been diagnosed with meningitis caused by the virus persisting in her brain. ${ }^{[225]^{*}}$ On 12 November, she was released from hospital after making a full recovery. ${ }^{[226]^{*}}$ However, on 23 February, Ms. Cafferkey was admitted for a third time, "under routine monitoring by the Infectious Diseases Unit ... for further investigations", according to a spokesperson. ${ }^{[227][228]}$

\section{Italy}

On 12 May 2015, it was reported that a nurse, who had been working in Sierra Leone, had been diagnosed with Ebola after returning home to the Italian island of Sardinia. He was treated at Spallanzani Hospital, the national reference center for Ebola patients. ${ }^{[229]}$ On 10 June, it was reported that he had recovered and was disease-free and he was released from hospital. ${ }^{[230]}$

\section{Spain}

Further information: Ebola virus disease cases in Spain

On 5 August 2014, the Brothers Hospitallers of Saint John of God confirmed that Brother Miguel Pajares, who had been volunteering in Liberia, had become infected. He was evacuated to Spain and died on $12 \mathrm{Au}-$ gust. ${ }^{[231]^{*}}$ On 21 September it was announced that Brother Manuel García Viejo, another Spanish citizen who was medical director at the San Juan de Dios Hospital in Lunsar, had been evacuated to Spain from Sierra Leone after being infected with the virus. His death was announced on 25 September. ${ }^{[232]^{*}}$

In October 2014, a nursing assistant, Teresa Romero, who had cared for these patients became unwell and on 6 October tested positive for Ebola, ${ }^{[233] *[234]}$ making this the first confirmed case of Ebola transmission outside of Africa. On 19 October, it was reported that Romero had recovered, and on 2 December the WHO declared Spain Ebola-free following the passage of 42 days since Teresa Romero was found to be cured. ${ }^{[235] *}$

\section{United States}

Further information: Ebola virus cases in the United States

On 30 September 2014, the CDC declared its first case of Ebola virus disease. It disclosed that Thomas Eric Duncan became infected in Liberia and traveled to Dallas, Texas on 20 September. On 26 September, he fell ill and sought medical treatment, but was sent home with 
antibiotics. He returned to the hospital by ambulance on 28 September and was placed in isolation and tested for Ebola. ${ }^{[236][237]^{*}}$ He died on 8 October. ${ }^{[238]^{*}}$ Two additional cases stemmed from Thomas Eric Duncan, when two nurses that had treated him tested positive for the

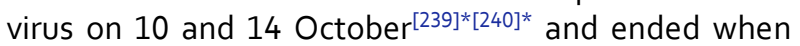
they were declared Ebola-free on 24 and 22 October, respectively. ${ }^{[241] *[242]}$

A fourth case was identified on 23 October 2014, when a physician, who had treated Ebola patients in Western Africa, himself tested positive for the virus. ${ }^{[243]}$ This case, however, had no relation to those originating from Thomas Eric Duncan-he recovered and was released from hospital on 11 November. ${ }^{[244]^{*}}$

\section{Countries with medically evacuated cases}

A number of people who had become infected with Ebola were medically evacuated for treatment in isolation wards in Europe or the US. They were mostly health workers with one of the NGOs in Western Africa. With the exception of a single isolated case in Spain, no secondary infections occurred as a result of the medical evacuations. The US accepted four evacuees and three were flown to Germany. ${ }^{[245][246] *[247]}$ France, ${ }^{[248][249]}$ Italy, $^{[250]}$ the Netherlands, ${ }^{[251]}$ Norway, ${ }^{[252][253]^{*}}$ Switzerland, ${ }^{[254]^{*}}$ and the United Kingdom received two patients (and five who were exposed). ${ }^{[255][256]}$

\section{Unrelated outbreak in the Democratic Republic of the Congo}

Further information: 2014 Democratic Republic of the Congo Ebola virus outbreak

In August 2014, the WHO reported an outbreak of Ebola virus in the Boende District, part of the northern Équateur province of the Democratic Republic of the Congo (DRC), where 13 people were reported to have died of Ebola-like symptoms. ${ }^{[257]}$ Genetic sequencing revealed that this outbreak was caused by the Zaire Ebola species, which is native to the DRC; there have been seven previous Ebola outbreaks in the country since 1976. The virology results and epidemiological findings indicated no connection to the epidemic in Western Africa. ${ }^{\text {[257][258] }}$

The index case was initially reported to have been a woman from Ikanamongo Village, who became ill with symptoms of Ebola after she had butchered a bush animal. [257][259] However, later findings suggested that there may have been several previous cases, and it was reported that pigs in the village may have been infected with Ebola some time before the first human case occurred. ${ }^{[260]}$ The WHO declared the outbreak over on 21
November 2014, after a total of 66 cases and 49 deaths. ${ }^{[261][262]}$

\section{Virology}

See also: Ebola virus disease $\int$ Virology, and Ebola virus

Ebola virus disease is caused by four of five viruses classified in the genus Ebolavirus. Of the four disease-causing viruses, Ebola virus (formerly and often still called the Zaire Ebola virus) is dangerous and is the virus responsible for the epidemic in Western Africa. [263][264] Since the discovery of the viruses in 1976, when outbreaks occurred in South Sudan (then Sudan) and Democratic Republic of the Congo (then Zaire), Ebola virus disease had been confined to areas in Middle Africa, where it is native. With the current outbreak, it was initially thought that a new species native to Guinea might be the cause, rather than being imported from Middle to Western Africa. ${ }^{[50]}$ However, further studies have shown that the outbreak was likely caused by an Ebola virus lineage that spread from Middle Africa via an animal host within the last decade, with the first viral transfer to humans in Guinea. [263][265]

In a study done by Tulane University, the Broad Institute and Harvard University, in partnership with the Sierra Leone Ministry of Health and Sanitation, researchers provided information about the origin and transmission of the Ebola virus that set the Western African outbreak apart from previous ones, including 341 genetic changes in the virion. ${ }^{[263]}$ Five members of the research

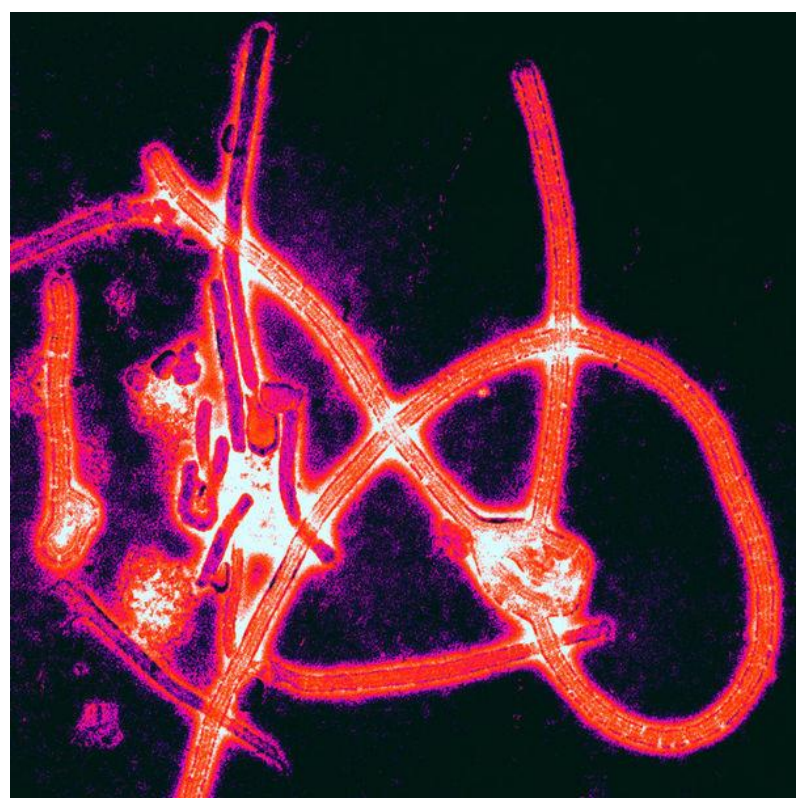

Figure 10 | Ebola virus particles using electron micrograph. Thomas W. Geisbert, CC BY 2.5 


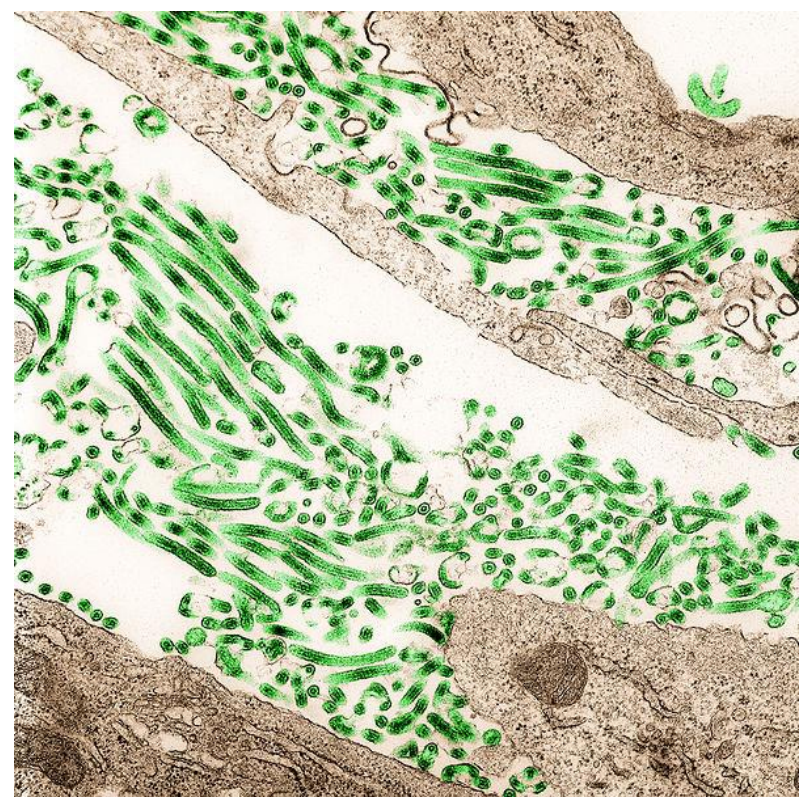

Figure 11 | Ebola virus particles. NIAID, CC BY 2.0

team became ill and died from Ebola before the study was published in August 2014. ${ }^{[263]}$

In a report released in August 2014, researchers tracked the spread of Ebola in Sierra Leone from the group first infected-13 women who had attended the funeral of the traditional healer, where they contracted the disease-giving them a unique opportunity to track how the virus had changed. This provided "the first time that the real evolution of the Ebola virus [could] be observed in humans." The research showed that the outbreak in Sierra Leone was sparked by at least two distinct lineages introduced from Guinea at about the same time. It is not clear whether the traditional healer was infected with both variants, or if perhaps one of the women attending the funeral was independently infected. As the Sierra Leone epidemic progressed, one virus lineage disappeared from patient samples, while a third one appeared. [266][267][268][269]

In January 2015, the media stated researchers in Guinea had reported mutations in the virus samples that they were looking at. According to them, "we've now seen several cases that don't have any symptoms at all, asymptomatic cases. These people may be the people who can spread the virus better, but we still don't know that yet. A virus can change itself to [become] less deadly, but more contagious and that's something we are afraid of."[270]* A 2015 study suggested that accelerating the rate of mutation of the Ebola virus could make the virus less capable of infecting humans. In this animal study, the virus became practically non-viable, consequently increasing survival. ${ }^{[271]}$

\section{Transmission}

See also: Ebola virus disease \Transmission

\section{Animal to human transmission}

The initial infection is believed to occur after an Ebola virus is transmitted to a human by contact with an infected animal's body fluids. Evidence strongly implicates bats as the reservoir hosts for ebolaviruses (however, despite considerable research, infectious ebolaviruses have never been recovered from bats). ${ }^{[272][273]}$ Bats drop partially eaten fruit and pulp, then land mammals such as gorillas and duikers feed on these fallen fruit. This chain of events forms a possible indirect means of transmission from the natural host to animal populations. ${ }^{[274]}$ As primates in the area were not found to be infected and fruit bats do not live near the location of the initial zoonotic transmission event in Meliandou, Guinea, it is suspected that the index case occurred after a child had contact with an insectivorous bat from a colony of Angolan free-tailed bats near the village. ${ }^{[275]}$

On 12 January, the journal Nature reported that the virus emergence could be found by studying how bushmeat hunters interacted with the ecosystem. ${ }^{[276]}$ The continent of Africa has experienced deforestation in several areas or regions, this may contribute to recent outbreaks, including this EVD epidemic, as initial cases have been in the proximity of deforested lands were fruit-eating bats natural habitat may be affected, though $100 \%$ evidence does not as yet exist ${ }^{[277][278]}$

\section{Human to human transmission}

Prior to this outbreak, it was believed that human-tohuman transmission occurred only via direct contact with blood or bodily fluids from an infected person who is showing symptoms of infection, by contact with the body of a person who had died of Ebola, or by contact with objects recently contaminated with the body fluids of an actively ill infected person. ${ }^{[279][280]}$ It is now known that the Ebola virus can be transmitted sexually. Over time, studies have suggested that the virus can persist in seminal fluid, with a study released in September 2016 suggesting that the virus may survive more than 530 days after infection. ${ }^{[103]}$ EBOV RNA in semen is not the same situation as perseverance of EBOV in semen, however the "clinical significance of low levels of virus RNA in convalescent" individuals who are healthy is unknown. ${ }^{[281][282]}$

In September 2014, the WHO had reported: "No formal evidence exists of sexual transmission, but sexual transmission from convalescent patients cannot be ruled 


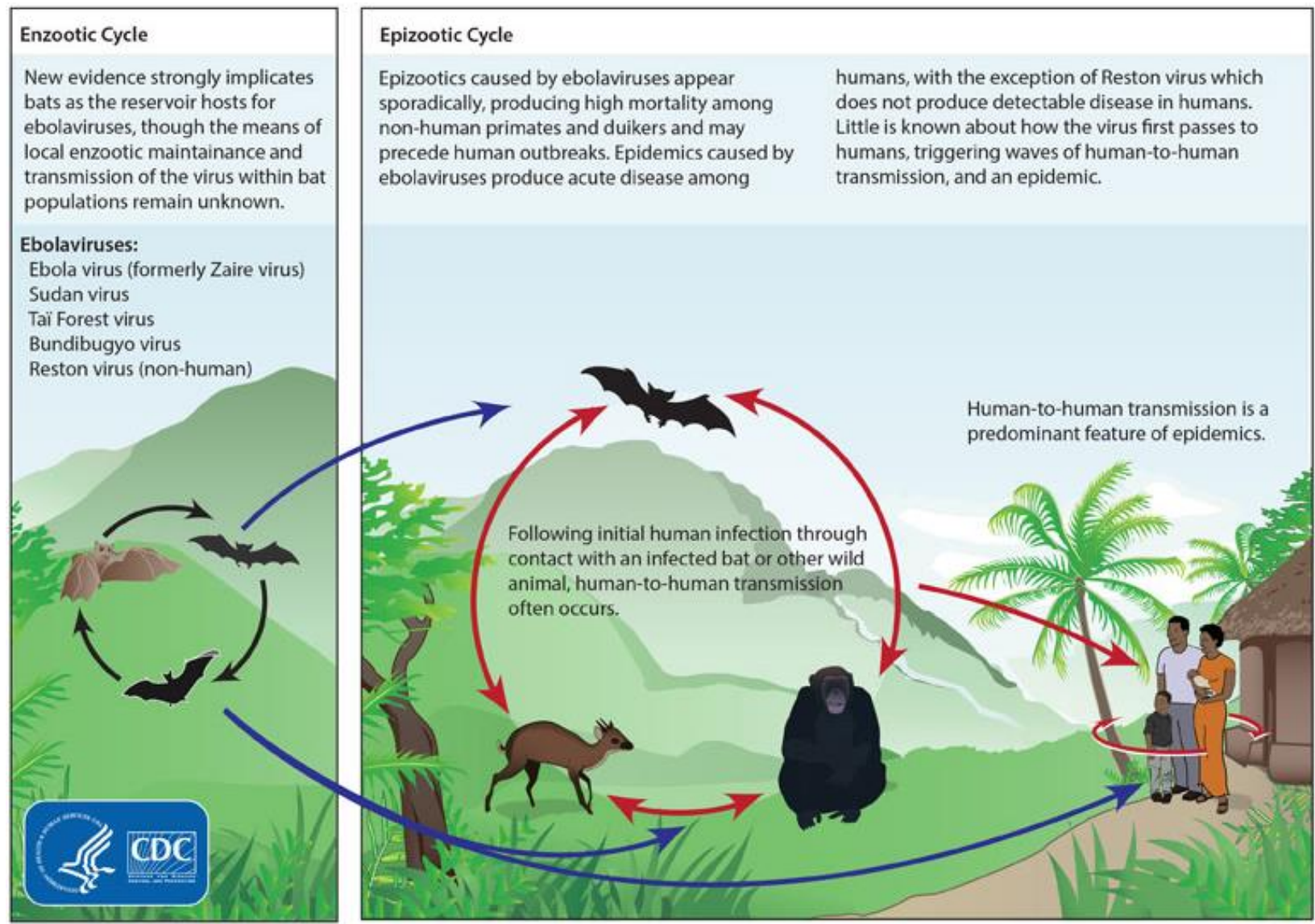

Figure 12 | The life cycles of the Ebolavirus. CDC, public domain

out. There is evidence that live Ebola virus can be isolated in seminal fluids of convalescent men for 82 days after onset of symptoms. Evidence is not available yet beyond 82 days."[283] In April 2015, following a report that the RNA virus had been detected in a semen sample six months after a man's recovery, the WHO issued a statement: "For greater security and prevention of other sexually transmitted infections, Ebola survivors should consider correct and consistent use of condoms for all sexual acts beyond three months until more information is available."[284][285]

The WHO based their new recommendations on a March 2015 case, in which a Liberian woman who had no contact with the disease other than having had unprotected sex with a man who had had the disease in October 2014, was diagnosed with Ebola. While no evidence of the virus was found in his blood, his semen revealed Ebola virus RNA closely matching the variant that infected the woman. However, "doctors don't know if there was any fully formed (and therefore infectious) virus in the guy's semen." It is known that testes are protected from the body's immune system to protect the developing sperm, and it is thought that this same protection may allow the virus to survive in the testes for an unknown time. ${ }^{[286]}$

On 14 September 2015, the body of a girl who had died in Sierra Leone tested positive for Ebola ${ }^{[129]^{*}}$ and it was suspected that she may have contracted the disease from the semen of an Ebola survivor who was discharged in March 2015. ${ }^{[130]^{*}}$ According to some news reports, a new study to be published in the New England Journal of Medicine indicated that the RNA virus could remain in the semen of survivors for up to six months, ${ }^{[287] *[288]}$ and according to other researchers, the RNA virus could continue in semen for 82 days and maybe longer. Furthermore, Ebola RNA had been found up to 284 days post-onset of viral symptoms. ${ }^{[289]}$

\section{Containment difficulties}

One of the primary reasons for spread of the disease is the low-quality, functioning health systems in the parts of Africa where the disease occurs. ${ }^{[290]}$ The risk of transmission is increased among those caring for people infected. Recommended measures when caring for those who are infected include medical isolation via the proper use of boots, gowns, gloves, masks and goggles, and sterilizing all equipment and surfaces. ${ }^{[291]}$ 
One of the biggest dangers of infection faced by medical staff requires their learning how to properly suit up and remove personal protective equipment. Full training for wearing protective body clothing can take 10 to 14 days. ${ }^{[292]}$ Even with proper isolation equipment available, working conditions such as lack of running water, climate control, and flooring have made direct care difficult. Two American health workers who contracted the disease and later recovered said that to the best of their knowledge, their team of workers had been following "to the letter all of the protocols for safety that were developed by the [CDC] and WHO", including a full body coverall, several layers of gloves, and face protection including goggles. One of the two, a physician, had worked with patients, but the other was assisting workers to get in and out of their protective gear, while wearing protective gear herself. ${ }^{[293]^{*}}$

Difficulties in attempting to halt transmission have also included the multiple disease outbreaks across country borders. ${ }^{[294]^{*}}$ Dr Peter Piot, the scientist who co-discovered the Ebola virus, stated that the outbreak was not following its usual linear patterns as mapped out in earlier outbreaks-this time the virus was "hopping" all over the Western African epidemic region. ${ }^{[67]^{*}}$ Furthermore, most past epidemics had occurred in remote regions, but this outbreak spread to large urban areas, which had increased the number of contacts an infected person might have and made transmission harder to track and break. ${ }^{[295]}$ On 9 December, a study indicated that a single individual introduced the virus into Liberia, causing the most cases of the disease in that country. ${ }^{[296]}$

\section{Containment and control}

Main article: Prevention of viral hemorrhagic fever

See also: Ebola virus disease \Prevention

In August 2014, the WHO published a road map of the steps required to bring the epidemic under control and to prevent further transmission of the disease within Western Africa; the coordinated international response worked towards realising this plan. ${ }^{[297]}$

\section{Surveillance and contact tracing}

Contact tracing is an essential method of preventing the spread of the disease, this requires effective community surveillance so that a possible case of Ebola can be registered and accurately diagnosed as soon as possible, and subsequently finding everyone who has had close contact with the case and tracking them for 21 days. However, this requires careful record-keeping by

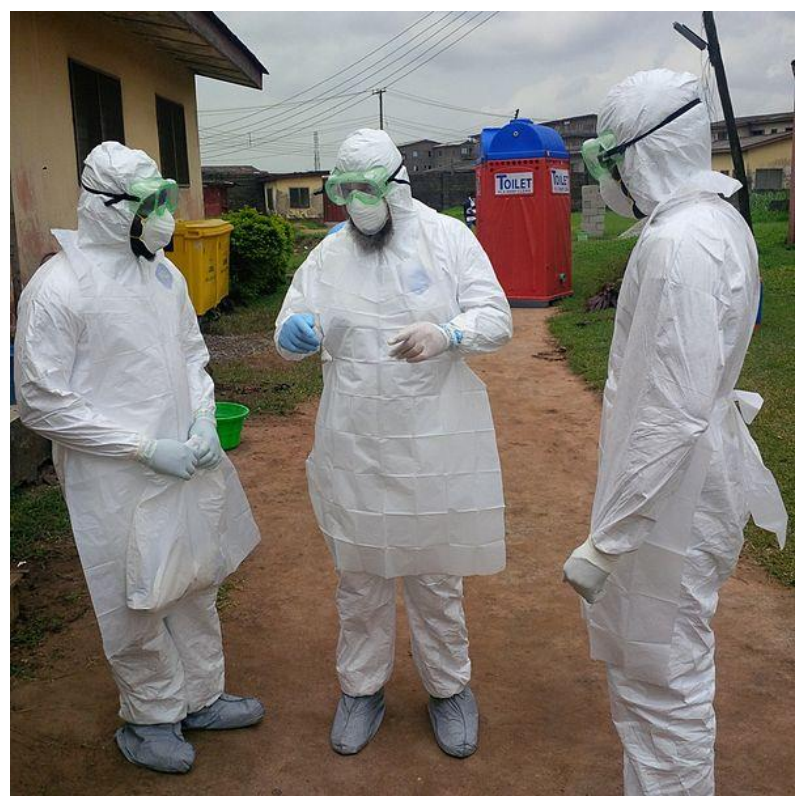

Figure 13 | Nigerian doctors training on PPE by WHO. CDC global, CC BY 2.0

properly trained and equipped staff. [298][299]* WHO Assistant Director-General for Global Health Security, Keiji Fukuda, said on 3 September 2014, "We don't have enough health workers, doctors, nurses, drivers, and contact tracers to handle the increasing number of cases." ${ }^{[300]}$ There was a massive effort to train volunteers and health workers, sponsored by United States Agency for International Development (USAID) ${ }^{[301]}$ According to WHO reports, 25,926 contacts from Guinea, 35,183 from Liberia and 104,454 from Sierra Leone were listed and traced as of 23 November 2014. ${ }^{[61]}$ According to one study, it is important to have a public awareness campaign to inform the affected community about the importance of contact tracing, so that true information can be obtained from the community. ${ }^{[302]}$

\section{Community awareness}

See also: Cultural effects of the Ebola crisis

To reduce the spread, the WHO recommended raising community awareness of the risk factors for Ebola infection and the protective measures individuals can take. ${ }^{[303]}$ These include avoiding contact with infected people and regular hand washing using soap and water. ${ }^{[304]^{*}} \mathrm{~A}$ condition of extreme poverty exists in many of the areas that experienced a high incidence of infections. According to the director of the NGO Plan International in Guinea, "The poor living conditions and lack of water and sanitation in most districts of Conakry pose a serious risk that the epidemic escalates into a crisis. People do not think to wash their hands when they do not have enough water to drink. ${ }^{\text {[[305]* }}$ One study 
showed that once people had heard of the Ebola virus disease, hand washing with soap and water improved, though socio-demographic factors influenced hygiene. ${ }^{[306]}$

A number of organisations enrolled local people to conduct public awareness campaigns among the communities in Western Africa. ${ }^{[307]}$ "... what we mean by social mobilization is to try to convey the right messages, in terms of prevention measures, adapted to the local context-adapted to the cultural practices in a specific area," said Vincent Martin, FAO's representative in Senegal. ${ }^{[308]}$

Denial in some affected countries also made containment efforts difficult. ${ }^{\left[{ }^{[09]}\right.}$ Language barriers and the appearance of medical teams in protective suits sometimes increased fears of the virus. ${ }^{[310]^{*}}$ In Liberia, a mob attacked an Ebola isolation centre, stealing equipment and "freeing" patients while shouting "There's no Ebola." "[311]* Red Cross staff were forced to suspend operations in southeast Guinea after they were threatened by a group of men armed with knives. ${ }^{[312]^{*}}$ In September, in the town of Womey in Guinea, suspicious inhabitants wielding machetes murdered at least eight aid workers and dumped their bodies in a latrine. ${ }^{[313]^{*}}$

An August 2014 study found that nearly two thirds of Ebola cases in Guinea were believed to be due to burial practices including washing of the body of one who had died. ${ }^{[27][28] *[29] *[49] *[58] *[314]}$ In November, WHO released a protocol for safe and dignified burial of people who die from Ebola virus disease. It encouraged inclusion of family and clergy, and gave specific instructions for Muslim and Christian burials. ${ }^{[315]}$ In the 21 January 2015 WHO road map update, it was reported that $100 \%$ of districts in Sierra Leone and $71 \%$ of districts in Guinea had a list of key religious leaders who promoted safe and dignified burials. ${ }^{[316]}$ Speaking on 27 January 2015, Guinea's Grand Imam, the country's highest cleric, gave a very strong message saying, "There is nothing in the Koran that says you must wash, kiss or hold your dead loved ones," and he called on citizens to do more to stop the virus by practising safer burying rituals that do not compromise tradition. ${ }^{[317]}$

During the height of the epidemic, most schools in the three most affected countries were shut down and remained closed for several months. During the period of closure UNICEF and its partners established strict hygiene protocols to be used when the schools were reopened in January 2015. They met with thousands of teachers and administrators to work out hygiene guidelines. Their efforts included installing hand-washing stations and distributing millions of bars of soap and chlorine and plans for taking the temperature of children and staff at the school gate. Their efforts were complicated by the fact that less than $50 \%$ of the schools in these three countries had access to running water. In August 2015, UNICEF released a report that stated, "Across the three countries, there have been no reported cases of a student or teacher being infected at a school since strict hygiene protocols were introduced when classes resumed at the beginning of the year after a months-long delay caused by the virus. "[318] Researchers presented evidence indicating that infected people that lived in low socioeconomic areas were more likely to transmit the virus to other socioeconomic status (SES) communities, in contrast to individuals in higher SES areas who were infected as well. ${ }^{[319]}$ Another study showed that, in Guinea, a satisfactory knowledge had not altered the level of comprehensive knowledge about the virus. As a consequence, the high level of misinterpretation was responsible for a low comprehensive knowledge about the virus; $82 \%$ of individuals believed that Ebola was the result of a virus (36.2\% thought that a higher power had caused it). ${ }^{[320]}$ A study on Nigeria's success story stated that, in this case, a prompt response by the government and proactive public health measures had resulted in the quick control of the outbreak. $^{[321]}$

During the height of the crisis, Wikipedia's Ebola page received 2.5 million page views per day, making Wikipedia one of the world's most highly used sources of trusted medical information regarding the disease. $^{[322][323]}$

\section{Travel restrictions and quarantines}

There was serious concern that the disease would spread further within Western Africa or elsewhere in the world, such as:

- Western Africa On 8 August 2014, a cordon sanitaire, a disease-fighting practice that forcibly isolates affected regions, was established in the triangular area where Guinea, Liberia, and Sierra Leone are separated only by porous borders and where 70 percent of the known cases had been found. [324]* This was subsequently replaced by a series of simple checkpoints for hand-washing and measuring body temperature on major roads throughout the region, manned either by local volunteers or by the military. ${ }^{[325][326]}$

- International Many countries considered imposing travel restrictions to or from the region. On 2 September 2014, WHO Director-General Margaret Chan advised against this, saying that they were not justified and that they would prevent medical experts from entering the affected areas. She also stated that they were "marginalizing the affected population and potentially worsening the crisis". UN officials working on the 


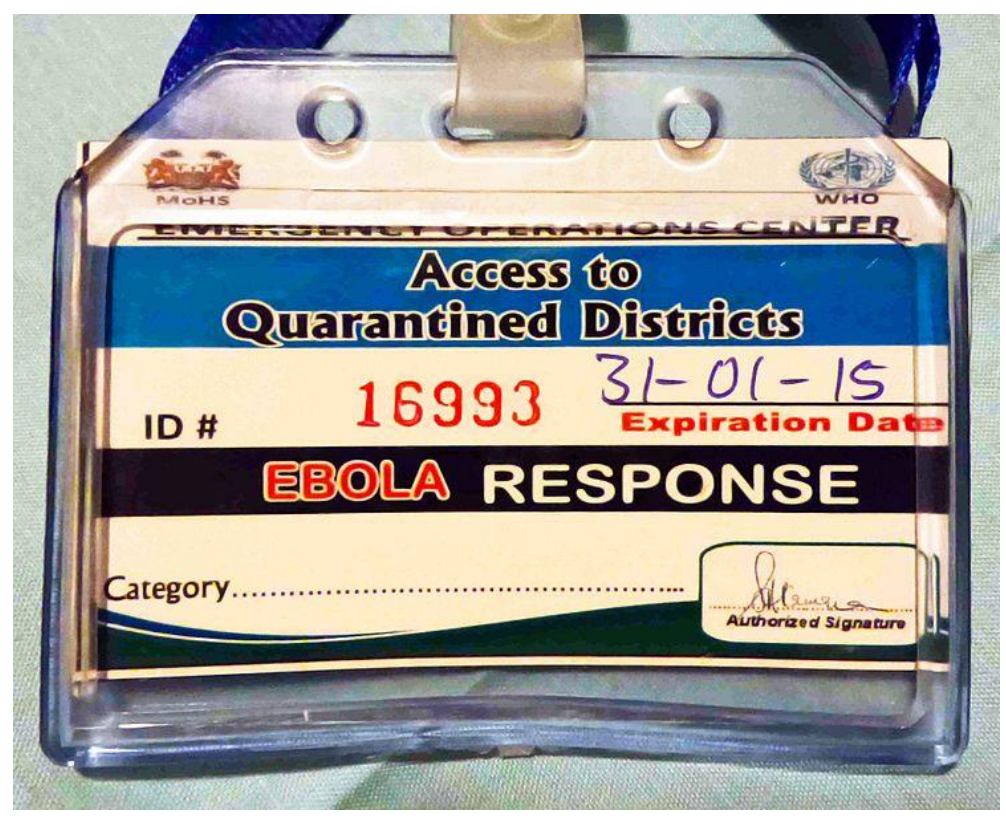

Figure 15 | Quarantine travel pass for individuals providing assistance. Julia Broska, CC BY-SA 4.0

ground also criticized the travel restrictions, saying the solution was "not in travel restrictions but in ensuring that effective preventive and curative health measures are put in place". ${ }^{[327] *}$ MSF also spoke out against the closure of international borders, calling them "another layer of collective irresponsibility" and added: "The international community must ensure that those who try to contain the outbreak can enter and leave the affected countries if need be." ${ }^{[36] *}$

In December 2015, during the 8th meeting of WHO's "IHR Emergency Committee regarding Ebola", it spoke out against further travel restrictions saying: "The Committee remains deeply concerned that 34 countries still enact inappropriate travel and transport measures and highlights the need to immediately terminate any such measures due to their negative impact, particularly on recovery efforts." ${ }^{328]}$ In December 2015, the CDC indicated that it would no longer make the recommendation for US citizens going to Sierra Leone to be extra careful. However, the CDC did further indicate that individuals travelling to the country should take precaution with sick people and body fluids. Additionally, individuals travelling to the country should avoid contact with animals. ${ }^{[329]}$

- $\quad$ Returning health workers There was concern that people returning from affected countries, such as health workers and reporters, may have been incubating the disease and become infectious after arriving. Guidelines for returning workers were issued by a number of agencies, including the $\mathrm{CDC}_{1}{ }^{[330]} \mathrm{MSF}_{,}{ }^{[331]^{*}}$ Public Health England, ${ }^{[332]}$ and Public Health Ontario. ${ }^{[333]^{*}}$

\section{Treatment}

See also: Ebola virus disease treatment research

\section{and Ebola vaccine}

No proven Ebola virus-specific treatment presently exists; ${ }^{[334][335]}$ however, measures can be taken to improve a patient's chances of survival. ${ }^{[336]^{*}}$ Ebola symptoms may begin as early as two days or as long as 21 days after one is exposed to the virus. Symptoms usually begin with a sudden influenza-like illness characterized by feeling tired, and pain in the muscles and joints. Later symptoms may include headache, nausea, and abdominal pain; this is often followed by severe vomiting and diarrhoea. ${ }^{[337][338]}$ In past outbreaks, it has been noted that some patients bleed internally and/or externally; however data published in October 2014 showed that this had been a rare symptom in the Western African outbreak. ${ }^{[339]}$ Another study published in October 2014 suggested that a person's genetic makeup may play a major role in determining how an infected person's body reacts to the disease, with some infected people experiencing mild or no symptoms while others progress to a very severe stage that includes bleeding. ${ }^{[340]}$

Without fluid replacement, such an extreme loss of fluids leads to dehydration, which in turn may lead to hypovolaemic shock-a condition in which there isn't enough blood for the heart to pump through the body. If a patient is alert and is not vomiting, oral rehydration therapy may be instituted, but patients who are vomiting or are delirious must be hydrated with intravenous (IV) therapy. ${ }^{[334]}{ }^{[341]}$ However, administration of IV fluids is difficult in the African environment. Inserting an IV

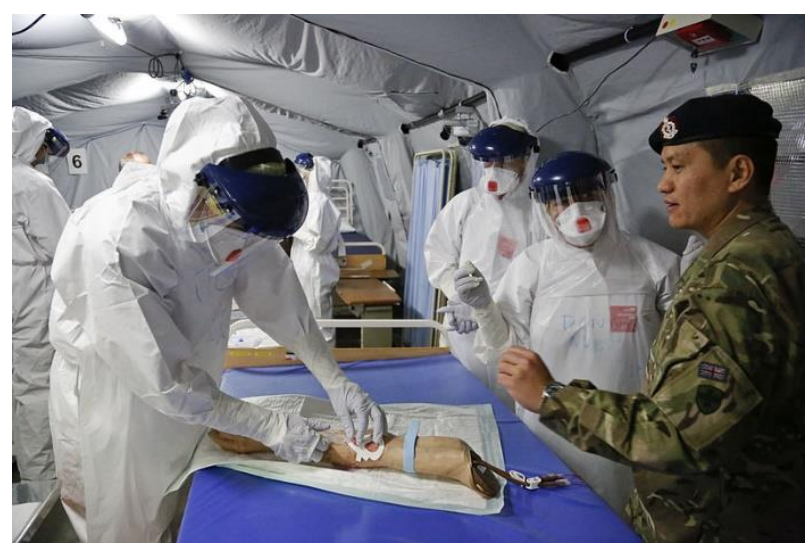

Figure 14 | Practising taking blood in PPE. DFID, CC BY 2.0 
needle while wearing three pairs of gloves and goggles that may be fogged is difficult, and once in place, the IV site and line must be constantly monitored. Without sufficient staff to care for patients, needles may become dislodged or pulled out by a delirious patient. A patient's electrolytes must be closely monitored to determine correct fluid administration, for which many areas did not have access to the required laboratory services. ${ }^{[342] *}$

Treatment centers were overflowing with patients while others waited to be admitted; dead patients were so numerous that it was difficult to arrange for safe burials. Based on many years of experience in Africa-and several months working in the present epidemic-MSF took a conservative approach. While using IV treatment for as many patients as they could manage, they argued that improperly managed IV treatment was not helpful and may even kill a patient when not properly managed. They also said that they were concerned about further risk to already overworked staff. ${ }^{[342]^{*}}$ While experts have studied the mortality rates of different treatment settings, and given the wide differences in variables that affected outcomes, adequate information had not yet been gathered to make a definitive statement about what constituted optimal care in the Western African setting..$^{[34]^{*}}$ Paul Farmer of Partners in Health, an NGO that only as of January 2015 had begun to treat Ebola patients, strongly supported IV therapy for all Ebola patients stating: "What if the fatality rate isn't the virulence of disease but the mediocrity of the medical delivery?" Farmer suggested that every treatment facility should have a team that specializes in inserting IVs, or better yet, peripherally inserted central catheter lines. ${ }^{[342]^{*}}$

\section{Prognosis}

Ebola virus disease has a high case fatality rate (CFR), which in past outbreaks varied between $25 \%$ and $90 \%$, with an average of about $50 \% .{ }^{[34]]}$ The epidemic caused significant mortality, with reported CFRs of up to $70 \% \cdot{ }^{[1][2][3][4]}$ Care settings that have access to medical expertise may increase survival by providing good maintenance of hydration, circulatory volume, and blood pressure. ${ }^{[339]}$

The disease affects males and females equally and the majority of those that contract Ebola disease are between 15 and 45 years of age. ${ }^{[1]}$ For those over 45 years, a fatal outcome was more likely in the Western African epidemic, as was also noted in preceding outbreaks. ${ }^{[339]}$ Only rarely do pregnant women survive-a midwife who worked with MSF in a Sierra Leone treatment cen- ter stated that she knew of "no reported cases of pregnant mothers and unborn babies surviving Ebola in Sierra Leone. "[345]* In September 2015, the WHO issued pregnancy guidance information entitled, "Interim Guidance on Ebola Virus Disease in Pregnancy."[346]

It has been suggested that the loss of human life was not limited to Ebola victims alone. Many hospitals had to shut down, leaving people with other medical needs without care. A spokesperson for the UK-based health foundation, the Wellcome Trust, said in October 2014 that "the additional death toll from malaria and other diseases [is] likely to exceed that of the outbreak itself". ${ }^{[30] *}$ Dr Paul Farmer stated: "Most of Ebola's victims may well be dying from other causes: women in childbirth, children from diarrhoea, people in road accidents or from trauma of other sorts." ${ }^{\text {[31]* }}$ As the epidemic drew to a close in 2015, a report from Sierra Leone showed that the fear and mistrust of hospitals generated by the epidemic had resulted in an $11 \%$ decline in facility-based births, and that those receiving care before or after birth fell by about a fifth. Consequently, between May 2014 and April 2015, the deaths of women during or just after childbirth rose by almost a third and those of newborns by a quarter, compared to the previous year. ${ }^{[34]]}$

Research suggests that many Ebola infections are asymptomatic, meaning that some infected people show no symptoms of the disease. For example, two studies done on previous outbreaks showed that $71 \%$ of seropositive individuals did not have the clinical disease in one outbreak and another study reported that $46 \%$ of asymptomatic close contacts of patients with Ebola were seropositive. ${ }^{[348]}$ On 22 January, the WHO issued Clinical Care for survivors of Ebola Virus Disease: interim guidance. The guidance covers specific issues like musculoskeletal pain, which is reported in up to $75 \%$ of survivors. The pain is symmetrical and more pronounced in the morning, with the larger joints most affected. There is also possible periarticular tenosynovitis affecting the shoulders. The WHO guidelines advise to distinguish non-inflammatory arthralgia from inflammatory arthritis. With regard to ocular problems, sensitivity to light and blurry vision have been indicated among survivors. Among the aftereffects of Ebola virus disease, uveitis and optic nerve disease could appear after an individual is discharged. Ocular problems could threaten sight in survivors, thus the need for prompt treatment. In treating such individuals, the WHO recommends urgent intervention if uveitis is suspected; this consists mainly of prednisone (a corticosteroid). Hearing loss has been reported in Ebola survivors 25\% of the time. Treatment, in the case of acute labyrinthitis (inner ear disorder), 
should be given within 10 days of the onset of symptoms and prochlorperazine, a vestibular sedative, may be administered for vertigo. ${ }^{[349]}$

\section{Post-Ebola virus syndrome}

See also: Post-Ebola virus syndrome

There are at least 17,000 people who have survived infection from the Ebola virus in Western Africa; some of them have reported lingering health effects. ${ }^{[350]}$ In early November, a WHO consultant reported: "Many of the survivors are discharged with the so-called Post-Ebola Syndrome. We want to ascertain whether these medical conditions are due to the disease itself, the treatment given or chlorine used during disinfection of the patients. This is a new area for research; little is known about the post-Ebola symptoms." [351][352]

In February 2015, a Sierra Leone physician said about half of the recovered patients she saw reported declining health and that she had seen survivors go blind. ${ }^{[353][354]}$ In May 2015, a senior consultant to the WHO said that the reports of eye problems were especially worrying because "there are hardly any ophthalmologists in Western Africa, and only they have the skills and equipment to diagnose conditions like uveitis that affect the inner chambers of the eye."[35]*

The medical director of a hospital in Liberia reported that he was seeing health problems in patients who had been in recovery for as long as nine months. Problems he was seeing included chronic pain, sometimes so severe that walking was difficult; eye problems, including uveitis; and headaches as the most common physical symptoms. "They're still very severe and impacting their life every day. These patients will need medical care for months and maybe years." A physician from the Kenema hospital in Sierra Leone reported similar health difficulties. ${ }^{[355]^{*}}$

In December 2014, a British aid worker who had just returned from Sierra Leone was diagnosed with Ebola. She was treated with survivors' blood plasma and experimental drugs and declared free of disease in January 2015. However, in October 2015, she again became critically ill and was diagnosed with meningitis. In this unprecedented case it is thought that the virus remained in her brain replicating at a very low level until it had replicated to a degree capable of causing clinical meningitis. The woman was treated and in November 2015 it was reported that she had recovered. ${ }^{[225] *[226] *}$

In terms of medical literature that are reviews, few articles have been published, such as Shantha, et al which discusses management of panuveitis and iris heterochromia. ${ }^{[356]}$

\section{Ebola survivor studies}

An observational study, done roughly 29 months after the 2007 Bundibugyo outbreak in Uganda, found that long-term sequelae (i.e. consequences) persisted among survivors. Symptoms included eye pain, blurred vision, hearing loss, difficulty swallowing, difficulty sleeping, arthralgias, memory loss or confusion, and "various constitutional symptoms controlling for age and sex". ${ }^{[348]}$

From August through December 2014, a total of 10 patients with Ebola were treated in US hospitals; of these patients, 8 survived. In March 2015, the CDC interviewed the survivors; they all reported having had at least one adverse symptom during their recovery period. The symptoms ranged from mild (e.g. hair loss) to more severe complications requiring re-hospitalization or treatment. The most frequently reported symptoms were lethargy or fatigue, joint pain, and hair loss. Sixtythree percent reported having eye problems including two who were diagnosed with uveitis, $75 \%$ reported psychological or cognitive symptoms, and $38 \%$ reported neural difficulties. Although most symptoms resolved or improved over time, only one survivor reported complete resolution of all symptoms. ${ }^{[357]}$

A study published in May 2015 discussed the case of lan Crozier, a Zimbabwe-born physician and American citizen who became infected with Ebola while he was working at an Ebola treatment center in Sierra Leone. He was transported to the US and successfully treated at Emory University Hospital. However, after discharge Crozier began to experience symptoms including low back pain, bilateral enthesitis of the Achilles tendon, paresthesias involving his lower legs, and eye pain, which was diagnosed as uveitis. His eye condition worsened and a specimen of aqueous humor obtained from his eye tested positive for Ebola. The authors of the study concluded that "further studies to investigate the mechanisms responsible for the ocular persistence of Ebola and the possible presence of the virus in other immune-privileged sites (e.g., in the central nervous system, gonads, and articular cartilage) are warranted." The authors also noted that $40 \%$ of participants in a survey of 85 Ebola survivors in Sierra Leone reported having "eye problems", though the incidence of actual uveitis was unknown. ${ }^{[358]}$

Another study, which was released in August 2015 looked at the health difficulties reported by survivors. Calling the set of symptoms "post-Ebolavirus disease syndrome", the research found symptoms that included "chronic joint and muscle pain, fatigue, anorexia, hearing loss, blurred vision, headache, sleep disturbances, 
low mood and short-term memory problems", and suggested the "implementation of specialized health services to treat and follow-up survivors". ${ }^{[359]}$

\section{Level of care}

In June 2014, it was reported that local authorities did not have the resources to contain the disease, with health centres closing and hospitals becoming overwhelmed. ${ }^{[360]^{*}}$ There were also reports that adequate personal protection equipment was not being provided for medical personnel. ${ }^{[361]^{*}}$ The Director-General of MSF said: "Countries affected to date simply do not have the capacity to manage an outbreak of this size and complexity on their own. I urge the international community to provide this support on the most urgent basis possible."[294]*

In late August, MSF called the situation "chaotic" and the medical response "inadequate." They reported that they had expanded their operations, but couldn't keep up with the rapidly increasing need for assistance, which had forced them to reduce the level of care: "It is not currently possible, for example, to administer intravenous treatments." Calling the situation "an emergency within the emergency", MSF reported that many hospitals had shut down due to lack of staff or fears of the virus among patients and staff, which had left people with other health problems without any care at all. Speaking from a remote region, an MSF worker said that a shortage of protective equipment was making the medical management of the disease difficult and that they had limited capacity to safely bury bodies. ${ }^{[362]}$

By September, treatment for Ebola patients had become unavailable in some areas. Speaking on $12 \mathrm{Sep}$ tember, WHO Director-General, Margaret Chan, said: "In the three hardest hit countries, Guinea, Liberia and

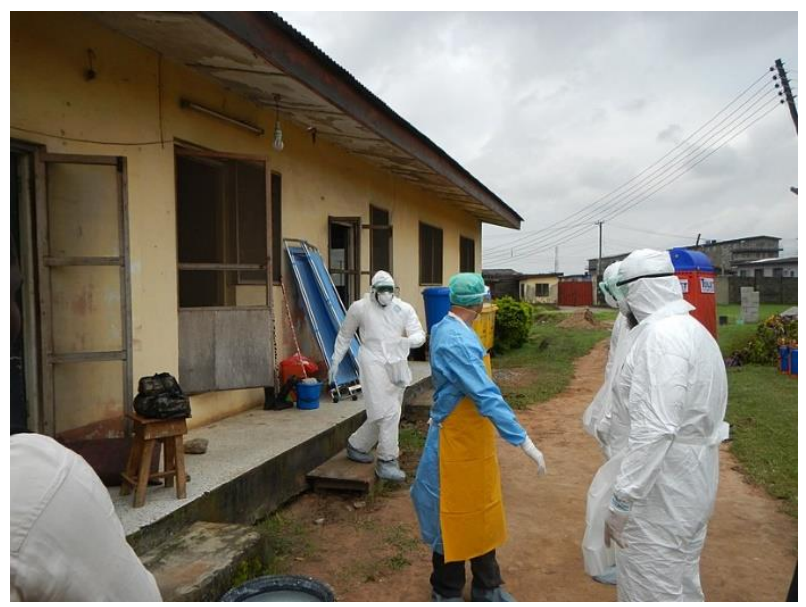

Figure 17 | WHO workers gear up to go to Ebola ward Nigeria, 2014. CDC global, CC BY 2.0
Sierra Leone, the number of new cases is moving far faster than the capacity to manage them in the Ebolaspecific treatment centers. Today, there is not one single bed available for the treatment of an Ebola patient in the entire country of Liberia."[363]* According to a WHO report released on 19 September, Sierra Leone was meeting only $35 \%$ of its need for patient beds, while for Liberia it was just $20 \%{ }^{[364]}$

In early December, the WHO reported that at a national level there were enough beds in treatment facilities to treat and isolate all reported Ebola cases, although their uneven distribution was resulting in serious shortfalls in some areas. Similarly, all affected countries had sufficient and widespread capacity to bury reported deaths; however, because not all deaths were reported, it was possible that the reverse could have been the case in some areas. WHO also reported that every district had access to a laboratory to confirm cases of Ebola within 24 hours of sample collection, and that all three countries had reported that more than $80 \%$ of registered contacts associated with known cases of Ebola virus disease were being traced, although contact tracing was still a challenge in areas of intense transmission and those with community resistance. ${ }^{[33]}$

\section{Healthcare settings}

A number of Ebola Treatment Centres were set up in the area, supported by international aid organisations and staffed by a combination of local and international staff. Each treatment centre is divided into a number of distinct and rigorously separate areas. For patients, there is a triage area, and low- and high-risk care wards. For staff, there are areas for preparation and decontamination. An important part of each centre is an arrangement for safe burial or cremation of bodies, required to

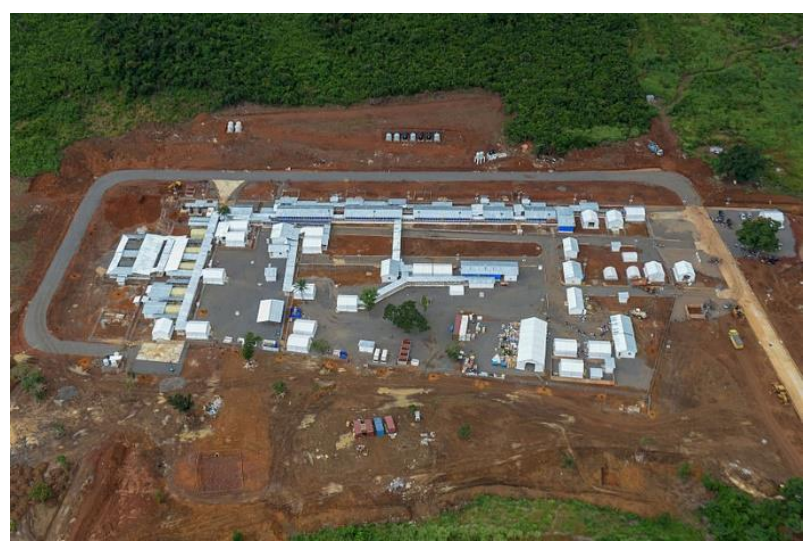

Figure 17 | Ebola treatment centre built by the UK in Kerry Town, Sierra Leone, in 2014.

Carl Osmond, Open Government Licence 
prevent further infection. ${ }^{[365] *[366]}$ In January 2015, a new treatment and research center was built by Rusal and Russia in the city of Kindia in Guinea. It is one of the most modern medical centers in Guinea. ${ }^{[367][368]}$ Also in January, MSF admitted its first patients to a new treatment centre in Kissy, an Ebola hotspot on the outskirts of Freetown, Sierra Leone. The center has a maternity unit for pregnant women with the virus. ${ }^{[369][370]}$

Although the WHO does not advise caring for Ebola patients at home, in some cases it became a necessity when no hospital treatment beds were available. For those being treated at home, the WHO advised informing the local public health authority and acquiring appropriate training and equipment. ${ }^{[371][372]^{*}}$ UNICEF, USAID and Samaritan's Purse began to take measures to provide support for families that were forced to care for patients at home by supplying caregiver kits intended for interim home-based interventions. The kits included protective clothing, hydration items, medicines, and disinfectant, among other items. ${ }^{[373][374]}$ Even where hospital beds were available, it was debated whether conventional hospitals are the best place to care for Ebola patients, as the risk of spreading the infection is high. ${ }^{[375]}$ In October, the WHO and non-profit partners launched a program in Liberia to move infected people out of their homes into ad hoc centres that could provide rudimentary care. ${ }^{[376]^{*}}$ Health facilities with low-quality systems for preventing infection were involved as sites of amplification during viral outbreaks. ${ }^{[377]}$

\section{Protective clothing}

The Ebola epidemic caused an increasing demand for protective clothing. A full set of protective clothing includes a suit, goggles, a mask, socks and boots, and an apron. Boots and aprons can be disinfected and reused, but everything else must be destroyed after use. Health workers change garments frequently, discarding gear that has barely been used. This not only takes a great deal of time but also exposes them to the virus because, for those wearing protective clothing, one of the most dangerous moments for contracting Ebola is while suits are being removed. ${ }^{[378]}$

The protective clothing sets that MSF uses cost about $\$ 75$ apiece. Staff who have returned from deployments to Western Africa say the clothing is so heavy that it can be worn for only about 40 minutes at a stretch. A physician working in Sierra Leone has said: "After about 30 or 40 minutes, your goggles have fogged up; your socks are completely drenched in sweat. You're just walking in water in your boots. And at that point, you have to exit for your own safety ... Here it takes 20-25 minutes to take off a protective suit and must be done with two

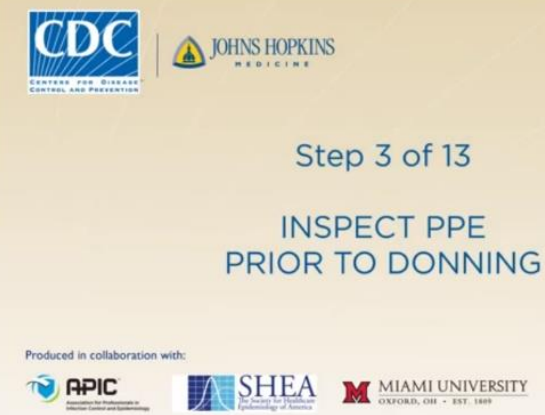

Figure 18 | Examining equipment. For video, follow this link: https://commons.wikimedia.org/wiki/File:CDC_PPE.webm $C D C$, public domain

trained supervisors who watch every step in a military manner to ensure no mistakes are made, because a slip up can easily occur and of course can be fatal."[292][379] By October, there were reports that protective outfits were beginning to be in short supply and manufacturers began to increase their production, ${ }^{[380]}$ but the need to find better types of suits has also been raised. [381]*

USAID published an open competitive bidding for proposals that address the challenge of developing "... new practical and cost-effective solutions to improve infection treatment and control that can be rapidly deployed; 1 ) to help health care workers provide better care and 2) transform our ability to combat Ebola". ${ }^{[382] *[383] *[384] *}$ On 12 December 2014, USAID announced the result of the first selection in a press release. ${ }^{[385]}$

On 17 December 2014, a team at Johns Hopkins University developed a prototype breakaway hazmat suit, and was awarded a grant from the USAID to develop it. The prototype has a small, battery-powered cooling pack on the worker's belt. "You'll have air blowing out that is room temperature but it's $0 \%$ humidity ... the Ebola worker is going to feel cold and will be able to function inside the suit without having to change the suit so frequently", said one source. ${ }^{[386]^{*}}$ In March, Google developed a tablet that could be cleaned with chlorine; it is charged wirelessly and can transmit information to servers outside the working area. ${ }^{[387][388]}$

The WHO recommends the use of 2 pairs of gloves, with the outer pair worn over the gown. Using 2 pairs may reduce the risk of sharp injuries; however, there is no evidence that using more than the recommended will give additional protection. WHO also recommends the use of a coverall, which is generally appraised in terms of its resistance to non-enveloped DNA virus. When a gown (or coverall) is worn, it should continue beyond the shoe covers. ${ }^{[389]}$ According to guidelines released by the CDC in August 2015, updates were put in place to improve 


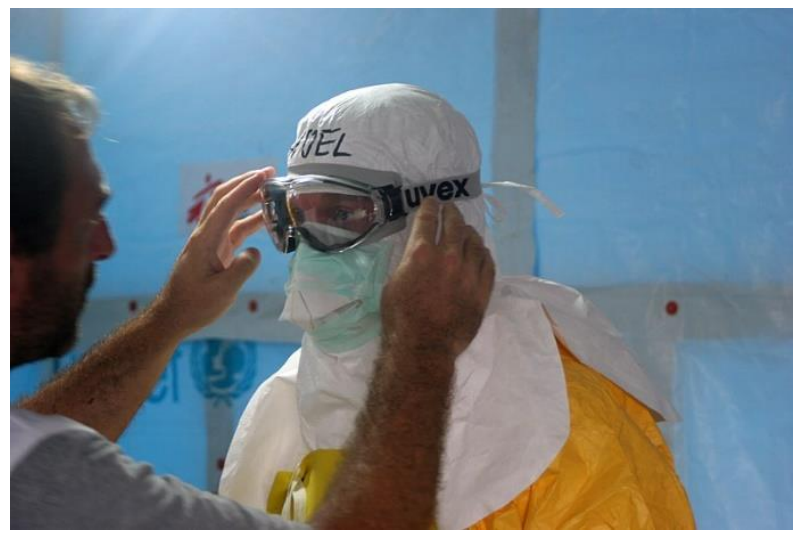

Figure 19 | CDC staff preparing to enter ETU in Liberia. CDC global, CC BY 2.0

the PAPR doffing method to make the steps easier, and affirm the importance of cleaning the floor where doffing has been done. Additionally, a designated doffing assistant was recommended to help in this process. The order in which boot covers are removed, by these guidelines, indicates their removal after the coverall or gown. Finally, a trained observer is to read to the healthcare worker each step in donning and doffing, but must not physically assist therein. ${ }^{[390]}$

\section{Healthcare workers}

In the hardest hit areas there have historically been only one or two doctors available to treat 100,000 people, and these doctors are heavily concentrated in urban areas. ${ }^{[295]}$ Ebola patients' healthcare providers, as well as family and friends, are at highest risk of getting infected because they are more likely to come in direct contact with their blood or body fluids. In some places affected by the outbreak, care may have been provided in clinics with limited resources, and workers could be in these areas for several hours with a number of Ebola infected patients. ${ }^{[391]}$ According to the $\mathrm{WHO}$, the high proportion of infected medical staff could be explained by a lack of adequate manpower to manage such a large outbreak, shortages of protective equipment or improper use of what was available, and "the compassion that causes medical staff to work in isolation wards far beyond the number of hours recommended as safe". [295] In August 2014, healthcare workers represented nearly 10 percent of cases and fatalities-significantly impairing the capacity to respond to an outbreak in an area already facing severe shortages. ${ }^{[392]}$ By 1 July 2015 , the WHO reported that a total of 874 health workers had been infected, of which 509 had died. [393]*

Among the fatalities was Samuel Brisbane, a former adviser to the Liberian Ministry of Health and Social Welfare, described as "one of Liberia's most high-profile doctors".[394]* In July 2014, leading Ebola doctor Sheik
Umar Khan from Sierra Leone also died in the out-

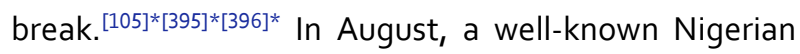
physician, Ameyo Adadevoh, died. ${ }^{[397]^{*}}$ Mbalu Fonnie, a licensed nurse-midwife and nursing supervisor at the Kenema hospital in Sierra Leone, with over 30 years of experience, died after contracting Ebola while caring for a fellow nurse who was pregnant and had the disease. Fonnie was also a co-author of a study that analyzed the genetics of the Ebola virus; five others contracted Ebola and died while working on the same study. ${ }^{[398]^{*}}$

Basing their choice on "the person or persons who most affected the news and our lives, for good or ill, and embodied what was important about the year", the editors of Time magazine in December 2014 named the Ebola health workers as Person of the Year. Editor Nancy Gibbs said: "The rest of the world can sleep at night because a group of men and women are willing to stand and fight. For tireless acts of courage and mercy, for buying the world time to boost its defenses, for risking, for persisting, for sacrificing and saving, the Ebola fighters are Time's 2014 Person of the Year. "[399]* According to an October 2015 report by the CDC, Guinean healthcare workers had 42.2 times higher Ebola infection rates than non-healthcare workers, and male healthcare workers were more affected than their female counterparts. The report indicated that $27 \%$ of Ebola infections among healthcare workers in Guinea occurred among doctors. The CDC report also stated that the Guinea Ministry of Health recorded males as representing $46 \%$ of the health workforce, and that $67 \%$ of Ebola infections among non-doctor healthcare workers occurred among males. The CDC further indicated that healthcare workers in Guinea were less likely to report contact with an infected individual than nonhealthcare workers. ${ }^{[400]}$

\section{Experimental treatments and testing}

Further information: Ebola virus disease treatment research

There is as yet no known confirmed medication or treatment for Ebola virus disease. The director of the US National Institute of Allergy and Infectious Diseases has stated that the scientific community is still in the early stages of understanding how infection with the Ebola virus can be treated and prevented. ${ }^{[401][402]}$ A number of experimental treatments are undergoing clinical trials. ${ }^{[403]^{*}[404]^{*}[405]}$ During the epidemic some patients received experimental blood transfusions from Ebola survivors, but a later study found that the treatment did not provide significant benefit. ${ }^{[406]}$ 


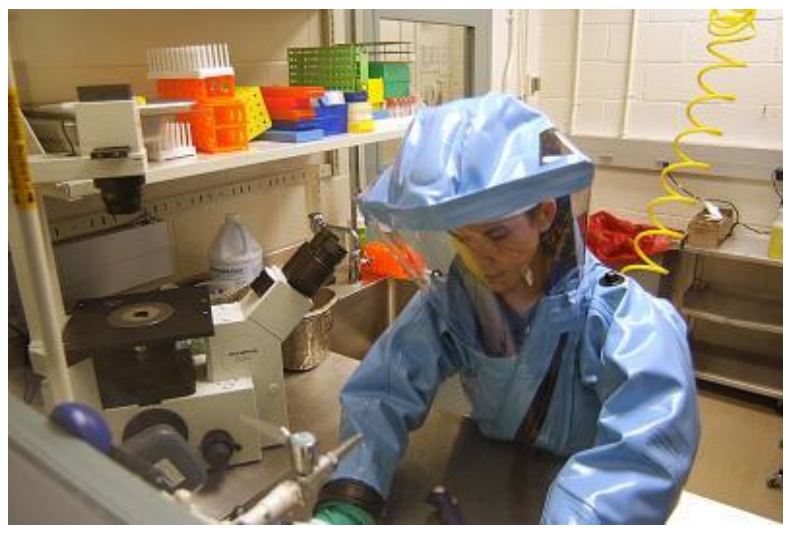

Figure 20| Researcher working on Ebola virus. USAMRIID, public domain

The effectiveness of potential treatments for any disease is usually assessed in a randomized controlled trial, which compares the outcome of those who received treatment to those who received a placebo (i.e. dummy treatment). However, randomized controlled trials are considered unethical when a disease is frequently fatal, as is the case with Ebola. In December 2015, a study was released that found that the viral load found in a patient's blood in the week after the onset of symptoms is a strong indication of the patient's likelihood to die or survive the disease. The researchers suggested that this information could help to assess the efficacy of proposed treatments more accurately in non-randomized clinical trials. ${ }^{[407]}$

Ebola control is hindered by the fact that current diagnostic tests require specialised equipment and highly trained personnel. Since there are few suitable testing centres in Western Africa, this delays diagnosis. As of February 2015 a number of rapid diagnostic tests were under trial. ${ }^{[408]}$ In September 2015, a new chip-based testing method that can detect Ebola accurately was reported. This new device allows for the use of portable instruments that can provide immediate diagnosis. $^{[409][410]}$

\section{Vaccines}

\section{Further information: Ebola vaccine}

Several Ebola vaccine candidates had been developed in the decade prior to 2014 and had been shown to protect nonhuman primates against infection, but none had yet been approved for clinical use in humans. ${ }^{[411][412] *[413][414] *}$ According to a 2015 review article, about 15 different vaccines were in preclinical stages of development, including DNA vaccines, viruslike particles and viral vectors. ${ }^{[415]}$ and another seven as yet unheard-of vaccines were being developed. Additionally, there were two phase III studies being conducted with two different vaccines. . ${ }^{[415]}$

In July 2015, researchers announced that a vaccine trial in Guinea had been completed that appeared to give protection from the virus. The vaccine, rVSVZEBOV ${ }_{1}^{[416]^{*}}$ had shown high efficacy in individuals, but more conclusive evidence was needed regarding its capacity to protect populations through "herd immunity" . The vaccine trial employed "ring vaccination", a technique that was also used in the 1970 s to eradicate smallpox, in which health workers control an outbreak by vaccinating all suspected infected individuals within the surrounding area. ${ }^{[44][455][417][418]}$

In December 2016, the results of the two-year Guinea trial were published announcing that rVSV-ZEBOV had been found to protect people who had been exposed to cases of Ebola. ${ }^{[21]}$ Of the nearly 6,000 people vaccinated, none had contracted Ebola after a ten-day period while in the group not vaccinated 23 cases developed. In addition to showing high efficacy among those vaccinated, the trial also showed that unvaccinated people were indirectly protected from Ebola virus through the ring vaccination approach, termed "herd immunity". The vaccine has not yet had regulatory approval, but it is considered to be so effective that 300,000 doses have already been stockpiled. Researchers have found the results "quite encouraging [but] there is still a lot more work to be done on vaccines for Ebola." Not yet known is the length of time that a vaccination will be effective and whether it will prove effective for the Sudan virus rather than only EBOV, which is responsible for the Western Africa outbreak. ${ }^{[22] *[419] *}$ Eventually, in April 2018 rVSV-ZEBOV Ebola vaccine was used to stop an outbreak for the first time, the 2018 Équateur province Democratic Republic of the Congo Ebola virus outbreak, with 3,481 people vaccinated. ${ }^{[420] *}$

\section{Outlook}

From the beginning of the outbreak, there existed considerable difficulty in getting reliable estimates-both of the number of people affected and of its geographical extent. ${ }^{[421]}$ The three most affected countriesGuinea, Liberia and Sierra Leone-are among the poorest in the world, with extremely low levels of literacy, few hospitals or doctors, low-quality physical infrastructure, and weakly functioning government institutions. ${ }^{[422]}$ One study yielded results of the spatio-temporal evolution of the viral outbreak. With the use of heat maps, it was determined that the outbreak did not 
uniformly unfold over the affected community areas. Growth in the regions of Guinea, Liberia and Sierra Leone was very different over time, indicating that monitoring the outbreak at district level was important. Visval inspection of incidence curves alone could not render the needed results or data; growth rates with a twodimensional heat map were used. Finally, the study showed that accurate predictions of growth were improbable, coupled with knowledge about the disease that was not fully adequate at the time (as there were now cases of sexual transmission). ${ }^{[423]}$

\section{Statistical measures}

Calculating the case fatality rate (CFR) accurately is difficult in an ongoing epidemic due to differences in testing policies, the inclusion of probable and suspected cases, and the inclusion of new cases that have not run their course. In August 2014, the WHO made an initial CFR estimate of 53\%, though this included suspected cases. ${ }^{[424] *[425]}$ In September and December 2014, the WHO released revised and more accurate CFR figures of $70.8 \%$ and $71 \%$ respectively, using data from patients with definitive clinical outcomes. ${ }^{[1][2][3]}$ The CFR among hospitalized patients, based on the three intense-transmission countries, was between $57 \%$ and $59 \%$ in January $2015 .{ }^{[4]}$

Mortality is measured by number of deaths in a population per the proportion of the population per unit of time ${ }^{[426]}$

The basic reproduction number, $R_{0}$, is a statistical measure of the average number of people expected to be infected by one person who has a disease. If the rate is less than 1 , the infection dies out; if it is greater than 1 , the infection continues to spread-with exponential growth in the number of cases. ${ }^{[427]}$ In September 2014, the estimated $R_{0}$ were 1.71 ( $95 \% \mathrm{Cl}, 1.44$ to 2.01 ) for Guinea, $1.83(95 \% \mathrm{Cl}, 1.72$ to 1.94$)$ for Liberia, and 2.02 ( $95 \% \mathrm{Cl}, 1.79$ to 2.26$)$ for Sierra Leone. ${ }^{[1][428][429]}$ In October 2014, the WHO noted that exponential increase of cases continued in the three countries with the most intense transmission. ${ }^{[430]}$

\section{Projections of future cases}

On 28 August 2014, the WHO released its first estimate of the possible total cases from the outbreak as part of its roadmap for stopping the transmission of the virus. It stated that "this Roadmap assumes that in many areas of intense transmission the actual number of cases may be two- to fourfold higher than that currently reported. It acknowledges that the aggregate case load of Ebola could exceed 20,000 over the course of this emergency. The Roadmap assumes that a rapid escalation of the complementary strategies in intense transmission, resource-constrained areas will allow the comprehensive application of more standard containment strategies within three months." The report included an assumption that some country or countries would pay the required cost of their plan, estimated at half a billion US dollars. ${ }^{[297]}$

When the WHO released these estimates, a number of epidemiologists presented data to show that the WHO projection of a total of 20,000 cases was likely an underestimate. ${ }^{[431][432]}$ On 9 September, Jonas Schmidt-Chanasit of the Bernhard Nocht Institute for Tropical Medicine in Germany, controversially announced that the containment fight in Sierra Leone and Liberia had already been "lost" and that the disease would "burn itself out". ${ }^{[433]^{*}}$

On 23 September 2014, the WHO revised their previous projection, stating that they expected the number of Ebola cases in Western Africa to be in excess of 20,000 by 2 November 2014. ${ }^{[1]}$ They further stated, that if the disease was not adequately contained it could become native in Guinea, Sierra Leone and Liberia, "spreading as routinely as malaria or the flu", ${ }^{[434]^{*}}$ and according to an editorial in the New England Journal of Medicine, eventually to other parts of Africa and beyond. ${ }^{[435]}$

In a report released on 23 September 2014, the CDC analysed the impact of under-reporting, which required correction of case numbers by a factor of up to 2.5. With this correction factor, approximately 21,000 total cases were estimated for the end of September 2014 in Liberia and Sierra Leone alone. The same report predicted that total cases, including unreported cases, could reach 1.4 million in Liberia and Sierra Leone by the end of January 2015 if no improvement in intervention or community behaviour occurred. ${ }^{[13]}$ However, at a congressional hearing on 19 November, the Director of the CDC said that the number of Ebola cases was no longer expected to exceed 1 million, moving away from the worst-case scenario that had been previously pre-

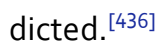

A study published in December 2014 found that transmission of the Ebola virus occurs principally within families, in hospitals and at funerals. The data, gathered during three weeks of contact tracing in August, showed that the third person in any transmission chain often knew both the first and second person. The authors estimated that between $17 \%$ and $70 \%$ of cases in Western Africa were unreported-far fewer than had been estimated in prior projections. The study concluded that the epidemic would not be as difficult to control as feared, if rapid, vigorous contact tracing and quarantines were employed. ${ }^{[437] *}$ 
Projections of future cases should also reflect the possibility that deforestation might have a hand in terms of the more recent Ebola outbreaks. It has been suggested that due to the clearing of forest for commercial use, various types of bats namely fruit bats may be taken out of their natural habitat and therefore into closer and potential contact with civilization. ${ }^{[278][277]}$

\section{Economic effects}

In addition to the loss of life, the outbreak had a number of significant economic impacts. In March 2015, the United Nations Development Group reported that due to a decrease in trade, closing of borders, flight cancellations, and drop in foreign investment and tourism activity fueled by stigma, the epidemic resulted in vast economic consequences both in the affected areas and throughout Africa. ${ }^{[38]}$ A September 2014 report in the Financial Times suggested that the economic impact of the Ebola outbreak could kill more people than the disease itself. ${ }^{[438]}$

With regard to Ebola and economic activity in the country of Liberia, a study found that $8 \%$ of automotive firms, $8 \%$ of construction firms, $15 \%$ of food businesses and $30 \%$ of restaurants had closed due to the Ebola outbreak. Montserrado county experienced up to $20 \%$ firm closure. This indicated a decline in the Liberian national economy during the outbreak, as well as an indication that the county of Montserrado was hardest hit economically. The capital city Monrovia suffered construction and restaurant unemployment the most, while outside the capital, the food and beverage sectors suffered economically. A recuperation in the economy, at the end of the outbreak, was expected to be more rapid in some sectors than in others. Also, if the massive decline in economic activity persisted, the authors suggested a focus on economic recovery in addition to support for the healthcare system. The World Bank had projected an estimated loss of $\$ 1.6$ billion in productivity for all three affected Western African countries combined for 2015. In Liberian counties that were less affected by the outbreak, the number of individuals employed fell by $24 \%$. Montserrado saw a $47 \%$ decline in employment per firm in contrast to what was obtained prior to the Ebola outbreak. ${ }^{[439]}$

\section{UNITED NATIONS DEVELOPMENT GROUP}

Figure 21 | UNDG, improves efficiency in needing countries. United Nations Development Group, public domain
Another study showed that the economic effect of the Ebola outbreak would be felt for years due to preexisting social vulnerability. The economic effects were being felt nationwide in Liberia, such as the termination of expansions in the mining business. Initial scenarios had placed expected economic losses at $\$ 25$ billion; however subsequent World Bank estimates were much lower, at about $12 \%$ of the combined GDP of the 3 worst hit countries. ${ }^{[440]}$ The authors went on to state that social vulnerability has multiple factors and proposed a classification based on multiple variables instead of single indicators such as food insecurity or lack of hospitals, which were problems faced by rural Liberians. In spite of the end of civil violence since 2003 and inflows from international donors, the reconstruction of Liberia had been very slow and non-productive-water delivery systems, sanitation facilities and centralized electricity were practically non-existent, even in Monrovia. Even before the outbreak, medical facilities did not have potable water, lighting or refrigeration. The authors indicated that lack of food and other economic effects would probably continue in the rural population long after the Ebola outbreak had ended. ${ }^{[440]}$

Other economic impacts were as follows:

- In August 2014 it was reported that many airlines had suspended flights to the area. ${ }^{[441]}$ Markets and shops had closed due to travel restrictions, a cordon sanitaire, or fear of human contact, which led to loss of income for producers and traders. ${ }^{[442]}$

- Movement of people away from affected areas disturbed agricultural activities. [443][444] The FAO warned that the outbreak could endanger harvests and food security in Western Africa, ${ }^{[445]^{*}}$ and that with all the quarantines and movement limitations placed on them, more than 1 million people could be food insecure by March 2015. ${ }^{[446]}$ By 29 July, the World Bank had given 10,500 tons of maize and rice seed to the 3 hardest-hit countries to help them to rebuild their agricultural systems. ${ }^{[447]}$

- Tourism was directly impacted in the affected countries. ${ }^{[448]}$ In April 2014, Nigeria reported that $75 \%$ of hotel business had been lost due to fears of the outbreak $_{i}{ }^{[449]}$ the limited Ebola outbreak had cost that country $\$ 8$ billion. ${ }^{[450]}$ Other African countries that were not directly affected by the virus also reported adverse effects on tourism. ${ }^{[451] *[452][453]}$ For example, in 2015, it was reported that Gambia's tourism had fallen below 50 percent of its normal business during the same period the prior year, ${ }^{[454][455]}$ Elmina Bay in Ghana had an $80 \%$ decrease in US tourism, ${ }^{[456]}$ and Kenya, ${ }^{[457]}$ Zimbabwe, ${ }^{[458]}$ Senegal, Zambia, and Tanzania also reported a drop. ${ }^{[459]}$

- $\quad$ Some foreign mining companies withdrew all non-essential personnel, deferred new investment, and cut back operations. ${ }^{[444][460] *[461]}$ In December 2014, it was 
reported that the iron ore mining company, African Minerals, had started the shutdown of its Sierra Leone operations because it was running low on income. ${ }^{[462]}$ In March 2015, it was reported that Sierra Leone had begun to diversify away from mining, due to the country's recent problems. ${ }^{[463]}$

In January 2015, Oxfam, a UK-based disaster relief organisation, indicated that a "Marshall Plan" (a reference to the massive plan to rebuild Europe after World War II) was needed so that countries could begin to financially assist those that had been worst hit by the virus. ${ }^{[464]}$ The call was repeated in April 2015 when the most-affected Western African countries asked for an $\$ 8$ billion "Marshall Plan" to rebuild their economies. Speaking at the World Bank and the International Monetary Fund (IMF), Liberian president Ellen Johnson Sirleaf said the amount was needed because "[o]ur health systems collapsed, investors left our countries, revenues declined and spending increased. "[465]

The IMF has been criticised for its lack of assistance in the efforts to combat the epidemic. In December 2014, a Cambridge University study linked IMF policies with the financial difficulties that prevented a strong Ebola response in the three most heavily affected countries, ${ }^{[466]^{*}}$ and they were urged by both the UN and NGOs who had worked in the affected countries to grant debt relief rather than low-interest loans. According to one advocacy group, "... yet the IMF, which has made a $\$ 9$ billion surplus from its lending over the last three years, is considering offering loans, not debt relief and grants, in response".[467]*[468] On 30 January 2015, the IMF reported it was close to reaching a deal on debt forgiveness. ${ }^{[469] *}$ On 22 December, it was reported that the IMF had given Liberia an additional $\$ 10$ million due to the economic impact of the Ebola virus outbreak. ${ }^{[470]}$

In October 2014, a World Bank report estimated overall economic impacts of between $\$ 3.8$ billion and $\$ 32.6$ billion, depending on the extent of the outbreak and speed of containment. It expected the most severe losses in the three affected countries, with a wider impact across the broader Western African region. ${ }^{[471] *[472]}$ On 13 April 2015, the World Bank said that they would soon announce a major new effort to rebuild the economies of the three hardest-hit countries. ${ }^{[473]}$ On 23 July, a World Bank poll warned that "we are not ready for another Ebola outbreak". [474]* On 15 December, the World Bank indicated that by 1 December 2015, it had marshalled $\$ 1.62$ billion in financing for the Ebola outbreak response. ${ }^{[475]^{*}}$

On 6 July 2015, UN Secretary-General Ban Ki-moon announced that he would host an Ebola recovery conference to raise funds for reconstruction, stating that the three countries hardest hit by Ebola needed about $\$ 700$ million to rebuild their health services over a two-year period. ${ }^{[476]^{*}}$ On 10 July, it was announced that the countries most affected by the Ebola epidemic would receive $\$ 3.4$ billion to rebuild their economies. ${ }^{[477][478]^{*}}$ On 29 September, the leaders of both Sierra Leone and Liberia indicated at the UN General Assembly the launch of a "Post-Ebola Economic Stabilization and Recovery Plan". ${ }^{479]}$ On 24 November, it was reported that due to the decrease in commodity prices and the Western African Ebola epidemic, China's investment in the continent had declined $43 \%$ in the first 6 months of 2015. ${ }^{[480]}$ On 25 January, the IMF projected a GDP growth of $0.3 \%$ for Liberia, that country indicating it would cut spending by 11 percent due to a stagnation in the mining sector, which would cause a domestic revenues drop of $\$ 57$ million. ${ }^{[481]}$

\section{Responses}

Further information: Responses to the Ebola virus epidemic in West Africa

In July 2014, the WHO convened an emergency meeting of health ministers from eleven countries and announced collaboration on a strategy to co-ordinate technical support to combat the epidemic. In August they published a roadmap to guide and coordinate the international response to the outbreak, aiming to stop ongoing Ebola transmission worldwide within 6-9 months, and formally designated the outbreak as a Public Health Emergency of International Concern. ${ }^{[35]}$ This is a legal designation used only twice before (for the 2009 H1N1 (swine flu) pandemic and the 2014 resurgence of poliomyelitis) that invokes legal measures on disease prevention, surveillance, control, and response, by 194 signatory countries. ${ }^{[482] *[483] *}$

In September 2014, the United Nations Security Council declared the Ebola virus outbreak in Western Africa "a threat to international peace and security" and unanimously adopted a resolution urging UN member states to provide more resources to fight the outbreak. ${ }^{[484]^{*}[485]^{*}}$ In October, WHO and the UN Mission for Ebola Emergency Response announced a comprehensive 90-day plan to control and reverse the Ebola epidemic. The ultimate goal was to have capacity in place for the isolation of $100 \%$ of Ebola cases and the safe burial of $100 \%$ of casualties by 1 January 2015 (the 90-day target). ${ }^{[486]}$ Many nations and charitable organizations cooperated to realise the plan, ${ }^{[487]}$ and a WHO situation report published mid-December indicated that the international community was on track to meet the 90 -day target. ${ }^{[488]}$ 
In May 2015, Dr Margaret Chan indicated, "demands on WHO were more than ten times greater than ever experienced in the almost 70-year history of this Organization"[489][490] and on 23 March, she stated that "the world remains woefully ill-prepared to respond to outbreaks that are both severe and sustained."[491]

\section{Criticism of WHO}

There was significant criticism of the WHO from some aid agencies because its response was perceived as slow and insufficient, especially during the early stages of the outbreak. ${ }^{[34] *[492] *}$ In October 2014, the Associated Press reported in an internal draft document that the WHO admitted "nearly everyone" involved in the Ebola response failed to notice factors that turned the outbreak into the largest on record, and that they had missed chances to stop the spread of Ebola due to "incompetent staff, bureaucracy and a lack of reliable information". [493]* Peter Piot, co-discoverer of the Ebola virus, called the WHO regional office in Africa "really not competent."[494]* In April 2015, the WHO admitted very serious failings in handling the crisis and indicated reforms for any future crises; "we did not work effectively in coordination with other partners, there were shortcomings in risk communications and there was confusion of roles and responsibilities". [495]* The Ebola crisis was discussed at the June 2015 G7 meeting. The leaders pledged to assist in carrying out WHO regulations. Critics criticized the $\mathrm{G} 7$ leaders, saying they were not committed enough in the fight against the possibility of future pandemics. ${ }^{[496][497]}$

In 2015 a panel of experts looked at the ways of preventing small outbreaks from becoming large epidemics. Their recommendations were published in the November issue of The Lancet. According to the panel, the epidemic had exposed problems in the national (and international) institutions responsible for protecting the public from the human consequences of infectious disease outbreaks such as the Ebola epidemic. The panel was highly critical of the WHO's management of the Ebola crisis noting that it took them months to respond

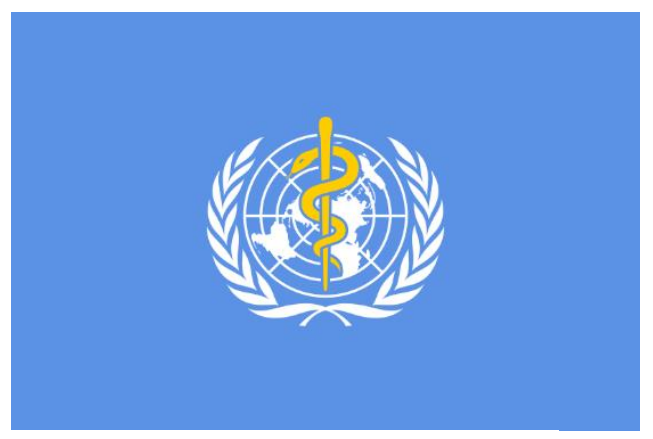

Figure 22 | WHO flag. WHO, public domain and when they did they were slow to act, poorly co-ordinated and inadequately informed. The report pointed out that the committee responsible for checking the WHO's actions during the outbreak (i.e. the WHO Ebola Interim Assessment Panel) had delayed responses due to worries about political resistance from the Western African leaders, economic consequences, and a system within the WHO that discouraged open debate about issues such as emergency declarations. The WHO may also have hesitated because it was criticised for creating panic by declaring a public health emergency during the relatively mild $2009 \mathrm{H} 1 \mathrm{~N} 1$ pandemic. This, the report states, showed the risks in having such consequential decision-making power in one individual-a risk made worse when there was no mechanism of responsibility for such leadership failure. [498][499]*[500]*

The panel outlined 10 recommendations for the prevention and handling of future infectious disease outbreaks. Included in the recommendations of the changes needed to fight future outbreaks is the creation of a U.N. Security Council health committee to expedite political attention to health issues and the establishment of a global fund to finance and accelerate the development of outbreak-relevant drugs and treatment. The report also noted that competent governance of the global system demanded political leadership and a WHO that is more focused and appropriately financed and whose integrity is restored through the application of adequate reforms and leadership. ${ }^{[498]}$

\section{Timeline of reported cases and deaths}

Main article: West African Ebola virus epidemic timeline of reported cases and deaths

See also: Ebola virus epidemic in West Africa timeline

\section{References}

1. WHO Ebola Response Team (23 September 2014). "Ebola virus disease in West Africa - the first 9 months of the epidemic and forward projections". New England Journal of Medicine 371 (16): 1481-1495. doi:10.1056/NEJMoa1411100. PMID 25244186. PMC 4235004. "... we estimate that the case fatality rate is $70.8 \%$ ( $95 \%$ confidence interval [CI], 69 to 73) among persons with known clinical outcome of infection."

2. "Case Fatality Rate for ebolavirus". University of Edinburgh. 2015. Archived from the original on 29 August 2014. Retrieved 28 January 2015.

3. Ebola response roadmap situation report (PDF) (Report). WHO. 31 December 2014. Retrieved 1 January 2015. The reported case fatality rate in the three intense-transmission countries among all cases for whom a definitive outcome is known is $71 \%$.

4. Ebola Situation report (Report). WHO. 12 January 2015. Retrieved 28 January 2015.

5. Wappes, Jim. "US health worker monitored as DRC Ebola nears 600 cases". CIDRAP. Retrieved 23 January 2019.

6. End of Ebola transmission in Guinea (Report). WHO Regional Office for Africa. Retrieved 30 October 2018. 
7. "Update: Mali confirms new case of Ebola, locks down Bamako clinic". Reuters. 12 November 2014. Retrieved 15 November 2014.

8. Ebola response roadmap situation report update (PDF) (Report). WHO. 7 November 2014. Retrieved 7 November 2014.

9. "Ebola virus disease - Italy". WHO. Retrieved 28 October 2016.

10. "Una enfermera que atendió al misionero fallecido García Viejo, contagiada de ébola" (in Spanish). El Mundo. 6 October 2014. Retrieved 6 October 2014.

11. Ebola outbreak situation report (PDF) (Report). WHO. 8 October 2014 Retrieved 15 October 2014

12. Ebola data and statistics (Report). WHO. Retrieved 9 June 2016.

13. Meltzer, Martin I.; Atkins, Charisma Y.; Santibanez, Scott et al. (26 September 2014). "Estimating the future number of cases in the Ebola epidemic - Liberia and Sierra Leone, 2014-2015". Morbidity and Mortality Weekly Report.

14. Worl, Justin (2014). "New Ebola Cases Could Hit 10,000 Per Week". Time. Retrieved 28 October 2016

15. Statement on the 1st meeting of the IHR Emergency Committee on the 2014 Ebola outbreak in West Africa (Report). WHO. Retrieved 13 January 2019.

16. WHO Director-General briefs media on outcome of Ebola Emergency Committee (Report). WHO. Retrieved 2 April 2016.

17. Interim advice on the sexual transmission of the Ebola virus disease (Report). WHO. Retrieved 28 October 2016.

18. WHO Director-General addresses the Executive Board (Report). WHO Retrieved 27 January 2016

19. WHO (10 June 2016). Situation Report Ebola (PDF) (Report). WHO. Retrieved 11 November 2016

20. Yasmin, Seema (29 February 2016). "Why Ebola Survivors Struggle with New Symptoms". Scientific American. Retrieved 9 September 2016.

21. Geisbert, Thomas W. (December 2016). "First Ebola virus vaccine to protect human beings?". The Lancet 389 (10068): 479-480. doi:10.1016/S0140-6736(16)32618-6. PMID 28017402

22. "Ebola vaccine results are encouraging - but preliminary". PBS. December 23, 2016.

23. "Ebola haemorrhagic fever in Zaire, 1976". Bulletin of the World Health Organization 56 (2): 271-293. 1978. PMID 307456. PMC 2395567.

24. Becker, Stephan; Matrosovich, Mikhail; Krähling, Verena; Schudt, Gordian; Dietzel, Erik (15 January 2017). "Functional Characterization of Adaptive Mutations during the West African Ebola Virus Outbreak". Journal of Virology 91 (2): e01913-e01916. doi:10.1128/JVI.01913-16. PMID 27847361. PMC 5215343.

25. Ebola response roadmap situation report (PDF) (Report). WHO. p. 6. Retrieved 25 September 2014.

26. "Runaway doctors and missing supplies cripple care in Ebola-hit Liberia". NBC News. Retrieved 8 October 2014

27. Ebola virus disease, West Africa (Report). WHO. 3 July 2014. Archived from the original on 28 July 2014. Retrieved 18 September 2014

28. "8 Ebola suspects freed by relatives in Sierra Leone". Global Post. Xinhua. 28 May 2014. Retrieved 21 June 2014.

29. "Growing Ebola outbreak threatens to overwhelm volunteers". Today Health. 8 June 2014. Retrieved 21 June 2014.

30. Cooper, Charlie (27 October 2014). "Ebola outbreak: Deaths from malaria and other diseases could soar while Africa's over-stretched healthcare systems fight the virus, expert warns". London: The Independent. Retrieved 28 October 2014

31. Farmer, Paul (23 October 2014). "Diary". London Review of Books. Retrieved 25 October 2014

32. McCauley, Lauren (3 September 2014). "As Ebola outbreak surges, health officials slam international 'Coalition of Inaction'". Common Dreams. Retrieved 7 September 2014

33. Ebola response roadmap situation report (PDF) (Report). WHO. 10 December 2014. Retrieved 11 December 2014.

34. Cheng, Maria; Satter, Raphael (20 March 2015). "Emails: UN health agency resisted declaring Ebola emergency". Associated Press. Retrieved 21 March 2015.

35. WHO Statement on the Meeting of the International Health Regulations Emergency Committee Regarding the 2014 Ebola Outbreak in West Africa (Report). WHO. 8 August 2014. Retrieved 8 August 2014.

36. "Ebola: the failures of the international outbreak response". Médecins Sans Frontières. Retrieved 5 March 2019.

37. news release (3 September 2014). "UN senior leaders outline needs for global Ebola response" (Press release). WHO. Retrieved 7 September 2014.

38. "West African economies feeling ripple effects of Ebola, says UN" (Press release). United Nations Development Programme. 12 March 2015. Retrieved 20 March 2015
39. Ebola situation report (Report). WHO. 28 January 2015. Retrieved 5 February 2015.

40. Ebola situation report (PDF) (Report). WHO. 8 April 2015. Retrieved 14 April 2015.

41. "Ebola numbers drop sharply in Guinea, Sierra Leone". CIDRAP. Retrieved 30 July 2015.

42. "Ebola countries record first week with no new cases". BBC News. 201510-07. Retrieved 8 October 2015.

43. "Liberian official urges calm as three new Ebola cases confirmed". The Guardian. Retrieved 21 November 2015.

44. Henao-Restrepo, Ana Maria; Longini, Ira M; Egger, Matthias; Dean, Natalie E; Edmunds, W John; Camacho, Anton; Carroll, Miles W. Doumbia, Moussa et al. (August 2015). "Efficacy and effectiveness of an rVSV-vectored vaccine expressing Ebola surface glycoprotein: interim results from the Guinea ring vaccination cluster-randomised trial". The Lancet 386 (9996): 857-866. doi:10.1016/S0140-6736(15)61117-5. PMID 26248676.

45. "World on the verge of an effective Ebola vaccine" (Press release). WHO. Retrieved 31 July 2015.

46. "An emergency within an emergency: caring for Ebola survivors" (Press release). WHO. 7 August 2015. Archived from the original on 13 August 2015. Retrieved 19 August 2015.

47. Burki, Talha Khan (1 July 2016). "Post-Ebola syndrome". The Lancet Infectious Diseases 16 (7): 780-781. doi:10.1016/S1473-3099(15)00259-5. PMID 27352759. Retrieved 6 March 2019.

48. "UN declares end to Ebola virus transmission in Guinea; first time all three host countries free". UN News Center. Retrieved 30 December 2015.

49. Kevin Sack; Sheri Fink; Pam Belluck; Adam Nossiter (29 December 2014). "How Ebola Roared Back". The New York Times. Retrieved 30 December 2014. The messages about don't touch the dead, wash your hands, if somebody is sick, leave them-these were all strange things, completely contrary to our tradition and culture.

50. Baize, Sylvain; Pannetier, Delphine; Oestereich, Lisa; Rieger, Toni (16 April 2014). "Emergence of Zaire Ebola Virus Disease in Guinea Preliminary Report". New England Journal of Medicine 371 (15): 1418 1425. doi:10.1056/NEJMoa1404505. PMID 24738640.

51. "Scientists Discover Ebola Virus in West African Bat". Columbia University Mailman School of Public Health. Retrieved 26 January 2019.

52. "Hollow tree in Guinea was Ebola's Ground Zero, scientists say". Mail \& Guardian Africa. AFP. 30 December 2014. Retrieved 1 January 2016.

53. Grady, Denise; Fink, Sheri (9 August 2014). "Tracing Ebola's Breakout to an African 2-Year-Old". The New York Times. Retrieved 11 April 2015.

54. Nassos Stylianou (27 November 2014). "How world's worst Ebola outbreak began with one boy's death". BBC News. Retrieved 11 April 2015.

55. Previous Updates: 2014 West Africa Outbreak (Report). CDC. Retrieved 11 April 2015.

56. Ebola virus disease, West Africa (Situation as of 16 April 2014) (Report). WHO. Archived from the original on 6 October 2014. Retrieved 18 September 2014.

57. Ebola virus disease, West Africa (Report). WHO. 18 July 2014. Archived from the original on 25 July 2014. Retrieved 18 September 2014.

58. "Sierra Leone hunts Ebola patient kidnapped in Freetown". BBC News. 25 July 2014. Retrieved 27 July 2014.

59. "Ebola outbreak: Sierra Leone escaped patient dies". BBC News. 27 July 2014. Retrieved 27 July 2014

60. Ebola response roadmap situation report (Report). WHO. 12 November 2014. Retrieved 16 November 2014

61. Ebola response roadmap situation report (PDF) (Report). WHO. 26 November 2014. Retrieved 27 November 2014.

62. Situation summary Data published on 2 December 2014 (Report). WHO. 2 December 2014. Retrieved 2 December 2014

63. Ebola data and statistics (Report). WHO. Retrieved 28 October 2016.

64. Ebola Situation Report (Report). WHO. 8 April 2015. Retrieved 29 October 2016.

65. Flare up of Ebola in Liberia (Report). WHO. Retrieved 26 November 2015

66. "West Africa declared free of Ebola transmission, but UN health agency warns new flare-ups possible". United Nations. 14 January 2016. Retrieved 6 March 2019

67. "Ebola virus is surging in places where it was beaten back: experts". CTV News. 8 September 2014. Retrieved 8 September 2014.

68. "Ebola cases double in Guinea in second week, says WHO". International Business Times UK. 2015-02-12. Retrieved 12 February 2015.

69. "In Guinea, Ebola Infections Double as Hidden Cases Discovered". VOA. Retrieved 8 February 2015

70. "Crowds attack Ebola facility, health workers in Guinea". Reuters. 14 February 2015. Retrieved 19 February 2015. 
71. "Guinea declares Ebola 'health emergency' in five regions". BBC News. 2015-03-29. Retrieved 29 March 2015

72. Fox, Maggie (13 May 2015). "Ebola Epidemic Slows Even More, WHO Says". NBC News.

73. "Guinea Families Transport Bodies in Public Taxis". ABC News. Retrieved 23 May 2015.

74. "Guinea Ebola cases climb due to transmissions at funerals | Fox News". web.archive.org. 29 May 2015. Retrieved 27 March 2019.

75. "Ebola crisis: Guineans jailed for putting corpse in taxi". BBC News. 2015 05-25. Retrieved 27 May 2015.

76. "Ebola threat to Guinea Bissau rises as border zone heats up". Yahoo! News. 2 June 2015. Retrieved 3 June 2015.

77. "United Nations News Centre". UN News Service Section. 24 June 2015. Retrieved 28 June 2015.

78. Maggie Fox. "Ebola Rates Plummet, But WHO Says More to Come". NBC News. Retrieved 7 August 2015

79. Ebola situation reports Archive (Report). WHO. 17 September 2015. Retrieved 20 September 2015.

80. Ebola Situation Report (PDF) (Report). WHO. 28 October 2015.

81. Searcey, Dionne (6 November 2015). "The Last Place on Earth With Ebola: Getting Guinea to Zero". The New York Times. ISSN 0362-4331. Retrieved 8 November 2015.

82. Ebola Situation Report (Report). WHO. 11 November 2015. Retrieved 6 March 2019.

83. "Guinea releases last 68 people from Ebola quarantine". Yahoo! News. 14 November 2015

84. Reuters Editorial (28 November 2015). "Guinea's last Ebola case, a baby girl, leaves hospital". Reuters. Retrieved 29 November 2015

85. Ebola Situation Report (Report). WHO. 2 December 2015.

86. Criteria for declaring the end of the Ebola outbreak in Guinea, Liberia or Sierra Leone (Report). WHO. Retrieved 10 December 2015.

87. Zoroya, Greg (17 November 2015). "Last known Ebola patient in West Africa recovers". USA Today. Retrieved 20 November 2015.

88. "End of Ebola transmission in Guinea". WHO. Retrieved 6 March 2019.

89. "Guinea says two people tested positive for Ebola". Reuters. 17 March 2016.

90. Reilly, Katie. "2 Test Positive for Ebola in Guinea". Time. Retrieved 2 April 2016.

91. "Fourth person dies of Ebola in Guinea". ABC News Australia. 2016-03-19. Retrieved 2 April 2016

92. "Ebola clinic reopens in Guinea after virus resurfaces". Yahoo! news. Retrieved 2 April 2016.

93. Hundreds of contacts identified and monitored in new Ebola flare-up in Guinea (Report). WHO. Retrieved 2 April 2016.

94. "Africa highlights: Tuesday 22 March 2016 as it happened". BBC News. Retrieved 2 April 2016

95. "Liberia Closes Border With Guinea After Ebola Flare-up". Voice of America. Retrieved 2 April 2016

96. "Fifth person dies in Guinea Ebola flare-up". Reuters. 22 March 2016. Retrieved 2 April 2016

97. Ebola Situation Report (Report). WHO. 30 March 2016. Retrieved 9 June 2016.

98. "Hundreds in Guinea get Ebola vaccine in fight against flare-up". Fox News. 1 April 2016. Retrieved 2 April 2016

99. Kucharski, Adam J.; Eggo, Rosalind M.; Watson, Conall H.; Camacho, Anton; Funk, Sebastian; Edmunds, W. John (2016). "Effectiveness of Ring Vaccination as Control Strategy for Ebola Virus Disease". Emerging Infectious Diseases 22 (1): 105-108. doi:10.3201/eid2201.151410. PMID 26691346. PMC 4696719.

100. "Ebola claims another victim in Guinea as vaccinations ramped up". Yahoo! News. 5 April 2016. Retrieved 6 April 2016.

101. "2 Test Positive for Ebola in Guinea". Time. Retrieved 31 October 2018.

102. Duraffour, Sophie; Rambaut, Andrew; Günther, Stephan; Keïta, Sakoba; Formenty, Pierre; Diarra, Abdoulaye; Djingarey, Mamoudou Harouna; Aylward, Raymond Bruce et al. (15 November 2016). "Resurgence of Ebola Virus Disease in Guinea Linked to a Survivor With Virus Persistence in Seminal Fluid for More Than 500 Days". Clinical Infectious Diseases 63 (10): 1353-1356. doi:10.1093/cid/ciw601. PMID 2758580o. PMC 5091350.

103. Diallo, Boubacar; Sissoko, Daouda; Loman, Nicholas J.; Bah, Hadja Aïssatou; Bah, Hawa; Worrell, Mary Claire; Conde, lya Saidou; Sacko, Ramata et al. (15 November 2016). "Resurgence of Ebola Virus Disease in Guinea Linked to a Survivor With Virus Persistence in Seminal Fluid for More Than 500 Days". Clinical Infectious Diseases 63 (10): 1353-1356. doi:10.1093/cid/ciw601. PMID 27585800. PMC 5091350

104. Liberia and Guinea discharge final Ebola patients in latest flare-up and begin 42 days of heightened surveillance (Report). WHO. Retrieved 9 June 2016.
105. "Sierra Leone 'hero' doctor's death exposes slow Ebola response". Fox News. 25 August 2014. Retrieved 25 August 2014.

106. "Sierra Leone shuts borders, closes schools to fight Ebola". Reuters. 11 June 2014. Retrieved 11 April 2015.

107. "Sierra Leone, Liberia deploy troops for Ebola". News 24. 4 August 2014. Retrieved 11 April 2015.

108. "Ebola cases appear in last untouched district in Sierra Leone". Fox News. 16 October 2014. Retrieved 16 October 2014.

109. "The Ebola Outbreak Is Getting Worse in Sierra Leone". VICE News. 201411-06. Retrieved 10 November 2014.

110. DiLorenzo, Sarah (4 November 2014). "Thousands in Sierra Leone break Ebola quarantine". Associated Press. Retrieved 5 November 2014.

111. "'Entire villages disappeared': Ebola deaths in Sierra Leone 'underreported'". Russia Today. Retrieved 7 November 2014.

112. "Ebola crisis: Sierra Leone hit by largely hidden outbreak; WHO says scores of bodies piled up". ABC News. 2014-12-10. Retrieved 11 December 2014

113. "Endless Ebola Epidemic? That's The 'Risk We Face Now, ' CDC Says". NPR. 15 December 2014. Retrieved 18 December 2014.

114. Sierra Leone: Ebola Virus Disease - Situation Report (PDF) (Report). Sierra Leone Ministry of Health and Sanitation. 15 December 2014. Archived from the original (PDF) on 20 December 2014. Retrieved 15 December 2014.

115. "Ebola: Sierra Leone begins house-to-house searches". BBC News. 201412-17. Retrieved 18 December 2014

116. Ebola Virus Disease - Situation Report (PDF) (Report). Sierra Leone Ministry of Health and Sanitation. 18 December 2014. Archived from the original (PDF) on 19 December 2014. Retrieved 19 December 2014.

117. "Ebola Could be 'Levelling Off' in Sierra Leone: WHO". Newsweek. 8 January 2015. Retrieved 11 January 2015.

118. "Sierra Leone predicts no new Ebola cases by March end (+video)". Christian Science Monitor. The Christian Science Monitor. 2015-01-14. Retrieved 15 January 2015.

119. Ebola Situation Report (Report). WHO. 21 January 2015. Retrieved 27 January 2019.

120. Gregg Zoroya (5 February 2015). "Downward Ebola trend suddenly reverses itself". USA Today. Retrieved 6 February 2015.

121. "Ebola-hit Sierra Leone to Reopen Schools March 30". VOA. Retrieved 7 February 2015.

122. "Decline in Ebola cases flattens, raising UN concern". Philadelphia Star. Retrieved 22 February 2015.

123. "More Ebola in Guinea, Sierra Leone last week, no Liberia cases says WHO". gnnliberia.com. Archived from the original on 2 April 2015. Retrieved 7 March 2015.

124. "Lowest Weekly Figure of Ebola Cases Reported in Nearly a Year". VOA. Retrieved 10 April 2015.

125. Alexandra Sifferlin (17 August 2015). "Sierra Leone Has First Week of No New Ebola Cases". Time. Retrieved 19 August 2015.

126. Sierra Leone begins 42-day countdown to be declared free of Ebola virus transmission. UN News Center. 26 August 2015.

127. "New Ebola death in Sierra Leone sets back efforts to beat epidemic". News 24. 1 September 2015. Retrieved 1 September 2015.

128. "Sierra Leone officials confirm 3 new cases of Ebola among high risk contacts with fatal case". Associated Press. 8 September 2015. Archived from the original on 21 November 2015. Retrieved 9 September 2015.

129. "New Ebola death reported in northern Sierra Leone". CTV News. 14 September 2015. Retrieved 14 September 2015.

130. "Hundreds quarantined as Ebola returns to north Sierra Leone district". Reuters. 14 September 2015. Retrieved 14 September 2015

131. "Sierra Leone Begins New Ebola 42-day Countdown". VOA. Retrieved 30 September 2015.

132. "Anticipation Grows as Sierra Leone Readies to be Declared Ebola-free". VOA. Retrieved 8 November 2015.

133. Ebola Situation Report (Report). WHO. 11 November 2015. Retrieved 27 January 2016.

134. "Ebola Situation Report". 9 December 2015. Retrieved 17 December 2015.

135. "Ebola virus: New case emerges in Sierra Leone". BBC News. 2016-01-15

136. Latest Ebola outbreak over in Liberia; West Africa is at zero, but new flare-ups are likely to occur (Report). WHO.

137. "Sierra Leone puts more than 100 people in quarantine after new Ebola death". The Guardian. 2016-01-17.

138. Government Press Statement: Confirmation of EVD Death in Sierra Leone (Report). WHO. 16 January 2016. Archived from the original on 22 January 2016. Retrieved 21 January 2016.

139. "Sierra Leone confirms second case of Ebola in a week". Yahoo! News. 20 January 2016. Retrieved 21 January 2016. 
140. Ebola in Sierra Leone: New case spreads community fear (Report). WHO. Retrieved 22 January 2016

141. "New Sierra Leone Ebola case responding to treatment". Yahoo! News. 22 January 2016. Retrieved 27 January 2016.

142. "Health Index". ABC News. Retrieved 9 June 2016.

143. "Sierra Leone Releases 70 from Ebola Quarantine". VOA. Retrieved 9 June 2016.

144. "Sierra Leone discharges last known Ebola patient". Reuters. 8 February 2016. Retrieved 9 June 2016 - via Reuters.

145. Latest Ebola outbreak over in Liberia; West Africa is at zero, but new flare-ups are likely to occur (Report). WHO. Retrieved 30 October 2018.

146. Ebola Situation Report (Report). WHO. 17 February 2016. Retrieved 9 June 2016.

147. WHO statement on end of Ebola flare-up in Sierra Leone (Report). WHO. Retrieved 9 June 2016

148. "Sierra Leone Ebola flare-up over, virus no longer spreading: WHO". Yahoo! News. Retrieved 17 March 2016.

149. "Sierra Leone Stops Mandatory Testing Of Corpses For Ebola". Agence France Presse. Retrieved 1 August 2016.

150. "2 of 5 Test Positive for Ebola in Liberia". Liberian Observer. 31 March 2014. Archived from the original on 9 July 2014. Retrieved 6 July 2014

151. "Ebola outbreak: Liberia shuts most border points". BBC News. 28 July 2014. Retrieved 28 July 2014.

152. Kwanue, C.Y. (1 August 2014). "In Compliance with Sirleaf's Mandate, UL Closed". Liberian Observer. Archived from the original on 8 August 2014. Retrieved 2 August 2014.

153. "Liberia shuts schools, quarantines communities in bid to halt Ebola". Reuters. 30 July 2014. Retrieved 30 July 2014.

154. "Ebola outbreak: Liberia shuts most border points". BBC News. 28 July 2014. Retrieved 28 July 2014.

155. Katty, Kay (7 October 2014). "Ebola outbreak: Liberia 'close to collapse' ambassador". BBC News Africa. Retrieved 8 October 2014.

156. "Runaway Doctors and Missing Supplies Cripple Care in Ebola-Hit Liberia". NBC News. Retrieved 8 October 2014

157. Ebola Response Roadmap Situation Report (PDF) (Report). WHO. 22 October 2014. Retrieved 22 October 2014

158. Liberia Ebola SitRep no. 157 (PDF) (Report). Liberia Ministry of Health and Social Welfare. 24 October 2014. Archived from the original (PDF) on 4 December 2014. Retrieved 24 October 2014.

159. Cumming-Bruce, Nick (29 October 2014). "Ebola Slowing in Liberia, WHO Says, but International Support Is Still Necessary". The New York Times. Retrieved 3 November 2014.

160. "Ebola state of emergency lifted in Liberia". CBS News. 14 November 2014. Retrieved 14 November 2014

161. "Ebola outbreak eases as world's largest treatment centre dismantled". ABC News. 2015-01-29. Retrieved 29 January 2015.

162. "Three New Ebola Cases in Liberia". The Disease Daily. 27 March 2015. Retrieved 28 March 2015

163. "allAfrica.com: Liberia: MSF Hands Over ELWA - 3 to Liberian Ministry of Health". allAfrica.com. Retrieved 29 April 2015

164. ABC News. "US Shuts Down Ebola Treatment Center in Liberia". ABC News. Retrieved 2 May 2015.

165. "Liberia names new health minister as it seeks to beat Ebola". Yahoo! News. 8 April 2015. Retrieved 16 April 2015.

166. How Liberia got to zero cases of Ebola (Report). WHO. 9 May 2015 Retrieved 10 May 2015

167. Fink, Sheri (9 May 2015). "Liberia Is Declared Free of Ebola, but Officials Sound Note of Caution".

168. Ebola situation report (PDF) (Report). WHO. 8 April 2015.

169. Ebola situation report (PDF) (Report). WHO. 6 May 2015.

170. Gladstone, Rick (3 July 2015). "Liberia: 200 Reportedly Had Contact With Ebola Victim". The New York Times.

171. "Ebola Returns To Liberia With A Mysterious Case Near Monrovia". NPR. 30 June 2015. Retrieved 1 July 2015.

172. "Liberia Reports Second Case of Ebola". NBC News. 1 July 2015.

173. "Liberia investigating animal link after Ebola re-emerges". Reuters. 2 July 2015.

174. Sena Quashie (2 July 2015). "In Liberia: Dog meat identified as possible source of Ebola". pulse.com.gh. Retrieved 4 July 2015.

175. Reuters. (7 July 2015)."Liberia: Dog Suspected in New Ebola Case Tests Negative for the Virus". The New York Times.

176. "Liberia Confirms 2 New Ebola Cases". ABC News. 9 July 2015. Retrieved 9 July 2015.

177. Tanya Basu (14 July 2015). "Ebola". Time.

178. Reuters. (20 July 2015)."Liberia: Ebola Patients Discharged, Last of the Country's Latest Wave". The New York Times.
179. Ebola transmission in Liberia over: Nation enters 90-day intensive surveillance period (Report). WHO. 3 September 2015.

180. "New Ebola case confirmed in Liberia". Los Angeles Times. 2015-11-20. Retrieved 2017-01-15.

181. "Liberia: Fears of Deadly Ebola Virus Reportedly Resurface in Liberia". allAfrica.com. Retrieved 21 November 2015.

182. Maggie Fox. "Ebola Returns to Liberia, Again". NBC News. Retrieved 21 November 2015

183. "Liberian health officials move to control Ebola outbreak in Monrovia". The Guardian. 22 November 2015. Retrieved 23 November 2015.

184. "Liberia Seeks US Help to Determine Cause of New Ebola Cases". Associated Press. 23 November 2015. Retrieved 24 November 2015.

185. ABC News. "Liberia Records 1st Ebola Death Since July". ABC News. Retrieved 26 November 2015.

186. "Liberia's last two Ebola patients recover, leave hospital". Yahoo! News. 3 December 2015. Retrieved 4 December 2015.

187. Reuters Editorial (11 December 2015). "Liberia's last Ebola contacts finish quarantine". Reuters. Retrieved 12 December 2015.

188. Ebola Situation Report (Report). WHO. 16 December 2015. Retrieved 25 December 2015.

189. Emma Farge; James Harding Giahyue (17 December 2015). "Female survivor may be cause of Ebola flare-up in Liberia". Reuters. Retrieved 22 December 2015.

190. Statement on the 8th meeting of the IHR Emergency Committee regarding the Ebola outbreak in West Africa (Report). WHO. Retrieved 23 December 2015.

191. Alexandra Sifferlin. "West Africa to Be Declared Ebola-Free, Health Officials Say". Time. Retrieved 14 January 2016.

192. Foundation, Thomson Reuters. "Liberia records new Ebola death, months after end of its outbreak". Reuters. Retrieved 9 June 2016

193. "International News | World News". ABC News. Retrieved 2017-01-15.

194. Emergency response to Ebola flare underway in Liberia. Case investigation widens to Guinea (Report). WHO. Retrieved 9 June 2016.

195. "Liberia records 97 Ebola contacts". The New Dawn Liberia. 7 April 2016 Archived from the original on 9 April 2016. Retrieved 7 April 2016.

196. Liberia and Guinea step up coordination to stem new cases of Ebola (Report). WHO. 8 April 2016. Retrieved 7 April 2016.

197. Farge, Emma. "Female survivor may be cause of Ebola flare-up in Liberia". Reuters. Retrieved 30 October 2018.

198. WHO declares the end of the most recent Ebola virus disease outbreak in Liberia (Report). WHO. Retrieved 9 June 2016.

199. PREVAIL treatment trial for men with persistent Ebola viral RNA in semen opens in Liberia (Report). NIH. 5 July 2016. Retrieved 1 August 2016

200. Camara, Ougna (29 March 2014). "Ebola Death Toll in Guinea Rises to 70 as Senegal Closes Border". Bloomberg News. Retrieved 31 March 2014

201. Ebola virus disease - Senegal (Report). WHO. 29 March 2014. Archived from the original on 5 September 2014. Retrieved 1 September 2014

202. "Guinean Who Brought Ebola To Senegal Recovers From Virus". Business Insider. Retrieved 20 September 2014

203. Ebola Response Roadmap Update, 22 September 2014 (PDF) (Report) WHO. 22 September 2014. Retrieved 22 September 2014.

204. "WHO congratulates Senegal on ending Ebola transmission". 17 October 2014. Retrieved 20 October 2014

205. Mark, Monica (6 August 2014). "Ebola Outbreak: Nurse who Treated First Victim in Nigeria Dies". The Guardian (Nigeria). Retrieved 7 August 2014.

206. "Nigeria in first step towards all-clear on Ebola". Yahoo News. 23 September 2014. Retrieved 26 September 2014.

207. Nigeria is now free of Ebola virus transmission (Report). WHO. 20 October 2014. Retrieved 20 May 2015.

208. WHO Declares Nigeria Ebola-Free (Report). WHO. Retrieved 22 July 2016.

209. Mali case, Ebola imported from Guinea Ebola situation assessment - 10 November 2014 (Report). WHO. Retrieved 11 November 2014.

210. "Ebola Outbreak 2014". NBC News. Retrieved 24 October 2014.

211. "Mali : Situation de la lutte contre la maladie à virus Ebola au Mali à la date du mercredi 19 novembre 2014" (in French). maliactu. 19 November 2014. Retrieved 26 November 2014

212. Mali confirms its second fatal case of Ebola virus disease (Report). WHO. Retrieved 14 November 2014

213. "UPDATE 2-Doctor who treated source of second Mali Ebola outbreak dies". Reuters. 21 November 2014. Retrieved 21 November 2014.

214. "Ebola crisis: Third death confirmed in Mali". BBC News. 12 November 2014. Retrieved 12 November 2014

215. "Mali records new Ebola case, linked to dead nurse". Reuters. 22 November 2014. Retrieved 22 November 2014. 
216. "Africa - Mali nears Ebola-free status as last patient leaves hospital". France 24. Retrieved 12 December 2014.

217. "Mali ends quarantines, could be Ebola-free soon". News24. 2014-12-16. Retrieved 17 December 2014

218. Cooper, Charlie (31 December 2014). "Ebola in the UK: Infected nurse Pauline Cafferkey treated with survivors' blood plasma and experimental drugs". London: The Independent. Retrieved 1 January 2015.

219. United Kingdom is declared free of Ebola virus disease (Report). WHO Europe. Retrieved 11 March 2015

220. "Ebola nurse: Pauline Cafferkey 'happy to be alive'". BBC News. 24 January 2015. Retrieved 11 April 2015.

221. "Ebola nurse Pauline Cafferkey 'in serious condition'". BBC News. 2015 10-09. Retrieved 9 October 2015.

222. Botelho, Greg (14 October 2015). "UK's first Ebola patient 'critically ill,' in isolation". CNN. Retrieved 16 October 2015

223. "Ebola nurse's close contacts identified". BBC News. 2015-10-12. Retrieved 16 October 2015.

224. "Ebola Nurse: 58 Monitored For Deadly Virus". Yahoo! News UK. 13 October 2015. Retrieved 16 October 2015.

225. "U.K. Ebola nurse has meningitis caused by persisting Ebola, doctors say". CBC. 21 October 2015. Retrieved 27 October 2015.

226. Wilcock, David (12 November 2015). "Ebola nurse Pauline Cafferkey released from London hospital after 'full recovery'". The Independent.

227. "Ebola nurse Pauline Cafferkey flying back to Royal Free Hospital amid ongoing tests". The Telegragh. 2016-02-23. Retrieved 28 October 2016

228. "Ebola nurse Pauline Cafferkey 'stable' after night in London hospital". BBC News. 24 February 2016. Retrieved 28 October 2016.

229. "Nurse in Italy tests positive for Ebola; was in Sierra Leone". The San Diego Union-Tribune. 2015-05-12. Retrieved 13 May 2015

230. Italian nurse cured of Ebola, AFP, 10 June 2015

231. "Muere el religioso español Miguel Pajares a causa del ébola". RTVE. 12 August 2014. Retrieved 12 August 2014.

232. "Ebola Outbreak: Spanish Missionary Manuel Garcia Viejo Dies of Deadly Virus in Madrid". International Business Times. 25 September 2014. Retrieved 25 September 2014.

233. "Nurse 'infected with Ebola' in Spain". BBC News. Retrieved 6 October 2014

234. "La enfermera ingresada en Alcorcón da positivo por ébola - La segunda prueba ha dado positivo y confirma el diagnóstico". Cadena Ser. 6 October 2014. Retrieved 11 April 2015

235. "WHO Says Spain Ebola-Free Following Nurse Recovery". ABC News. 2 December 2014. Retrieved 2 December 2014.

236. CDC and Texas Health Department Confirm First Ebola Case Diagnosed in the U.S. (Report). CDC. 1 October 2014. Retrieved 1 October 2014.

237. Nick Allen (1 October 2014). "First Ebola victim in America was sent home with antibiotics". London: The Telegraph. Retrieved 11 April 2015

238. "Thomas Eric Duncan: First Ebola death in U.S." CNN. 8 October 2014. Retrieved 8 October 2014.

239. Fernandez, Manny (12 October 2014). "Texas Health Worker Tests Positive for Ebola". The New York Times. Retrieved 12 October 2014

240. "Second Ebola-infected nurse ID'd; flew domestic flight day before diagnosis". Fox News. 15 October 2014. Retrieved 15 October 2014.

241. "Virus Free: Ebola-Infected Nurse Nina Pham to Go Home". NBC News. 24 October 2014. Retrieved 11 April 2015.

242. "Nurse Amber Vinson free of Ebola virus, family says". Yahoo! News. 23 October 2014. Retrieved 23 October 2014.

243. "New York Doctor Just Back From Africa Has Ebola". NBC News. 23 October 2014. Retrieved 23 October 2014

244. Hartocollis, Anemona (10 November 2014). "Craig Spencer, New York Doctor With Ebola, Will Leave Bellevue Hospital". The New York Times. Retrieved 11 April 2015.

245. "Infektion: Ebola-Patient in Leipziger Klinik gestorben". De Zeit. 14 October 2014. Retrieved 14 October 2014.

246. "Ugandan doctor cured of Ebola in German hospital". Yahoo! News. 4 December 2014. Retrieved 4 December 2014.

247. "Hamburg clinic dismisses Ebola patient" (in German). 2014-10-04 Retrieved 4 October 2014

248. "French MSF nurse cured of Ebola". Retrieved 4 October 2014

249. "Ebola: I'agent de l'Unicef soigné à l'hôpital Bégin a quitté la France "guéri"'" (in French). Retrieved 24 November 2014.

250. "Italy doctor with Ebola has recovered: reports". Deccan Chronicle. 2 January 2015. Retrieved 2 January 2015.

251. "UN: Nigerian peacekeeper recovers from Ebola". The San Diego UnionTribune. 2014-12-23. Retrieved 28 December 2014.

252. "Jeg er utrolig takknemlig" (in Norwegian). 2014-10-20. Retrieved 20 October 2014
253. "Norwegian Ebola Patient Cured". Yahoo! News. 20 October 2014 Retrieved 20 October 2014

254. "Felix Baez, Cuban doctor with Ebola, recovers in Geneva". CBC News. 6 December 2014. Retrieved 6 December 2014.

255. "BBC News - Ebola: Seventh British health worker sent home". BBC News. 2015-03-16. Retrieved 19 March 2015

256. "British medic declared free of Ebola". BBC News. 27 March 2015. Retrieved 27 March 2015.

257. Ebola virus disease - Democratic Republic of Congo E-mail Print Epidemiology and surveillance (Report). WHO (WHO). Retrieved 11 April 2015

258. Virological analysis: no link between Ebola outbreaks in west Africa and Democratic Republic of Congo (Report). WHO. 2 September 2014. Retrieved 7 September 2014

259. Outbreaks Chronology: Ebola Virus Disease (Report). CDC. Retrieved 31 May 2015.

260. "Ebola sleuths scour DR Congo jungle for source of outbreak". Yahoo! News. 23 October 2014. Retrieved 23 October 2014.

261. WHO declares end of Ebola outbreak in the Democratic Republic of Congo (Report). WHO. Retrieved 22 November 2014

262. Ebola response roadmap situation report update (PDF) (Report). WHO. 29 October 2014. Retrieved 3 November 2014.

263. Gire, S. K.; Goba, A.; Andersen, K. G.; Sealfon, R. S. G.; Park, D. J.; Kanneh, L.; Jalloh, S.; Momoh, M. et al. (28 August 2014). "Genomic surveillance elucidates Ebola virus origin and transmission during the 2014 outbreak". Science 345 (6202): 1369-1372. doi:10.1126/science.1259657. PMID 25214632. PMC 4431643

264. Kuhn, Jens H.; Becker, Stephan; Ebihara, Hideki; Geisbert, Thomas W.; Johnson, Karl M.; Kawaoka, Yoshihiro; Lipkin, W. Ian; Negredo, Ana I. et al. (30 October 2010). "Proposal for a revised taxonomy of the family Filoviridae: classification, names of taxa and viruses, and virus abbreviations". Archives of Virology 155 (12): 2083-2103. doi:10.1007/s00705-010-0814-x. PMID 21046175. PMC 3074192.

265. Schoepp, Randal J.; Rossi, Cynthia A.; Khan, Sheik H.; Goba, Augustine; Fair, Joseph N. (2014). "Undiagnosed Acute Viral Febrile Illnesses, Sierra Leone". Emerging Infectious Diseases 20 (7): 1176-1182. doi:10.3201/eid2007.131265. PMID 24959946. PMC 4073864.

266. Vogel, Gretchen (29 August 2014). "Genomes reveal start of Ebola outbreak". Science 345 (6200): 989-990. doi:10.1126/science.345.6200.989. PMID 25170128

267. Public Health England. PHE study finds Ebola virus mutated slower than first thought (Report). Public Health England. Retrieved 15 July 2015.

268. "Scientists Release Ebola Sequencing Data to Global Research Community Online". Drug Discovery \& Development. 2015-06-03. Retrieved 7 June 2015

269. Simon-Loriere, Etienne; Faye, Ousmane; Faye, Oumar; Koivogui, Lamine; Magassouba, Nfaly; Keita, Sakoba; Thiberge, Jean-Michel; Diancourt, Laure et al. (6 August 2015). "Distinct lineages of Ebola virus in Guinea during the 2014 West African epidemic". Nature 524 (7563): 102-104. doi:10.1038/nature14612. PMID 26106863.

270. Kevin McSpadden (29 January 2015). "Ebola Virus has Mutated, Scientists Say". Time. Retrieved 31 January 2015.

271. Alfson, K. J.; Worwa, G.; Carrion Jr, R.; Griffiths, A. (16 December 2015). "Determination of the Spontaneous Mutation Frequency of Ebola virus and Exploitation of this Therapeutically". Journal of Virology 90 (5): 23452355. doi:10.1128/JVI.02701-15. PMID 26676781. PMC 4810732.

272. Griensven, Johan van; Günther, Stephan; Clerck, Hilde de; McElroy, Anita K.; Malvy, Denis (2 March 2019). "Ebola virus disease". The Lancet 393 (10174): 936-948. doi:10.1016/S0140-6736(18)33132-5. PMID 30777297.

273. Ng, Melinda; Ndungo, Esther; Kaczmarek, Maria E; Herbert, Andrew S; Binger, Tabea; Kuehne, Ana I; Jangra, Rohit K; Hawkins, John A et al. (23 December 2015). "Filovirus receptor NPC1 contributes to species-specific patterns of ebolavirus susceptibility in bats". eLife 4: e11785. doi:10.7554/eLife.11785. PMID 26698106. PMC 4709267.

274. Gonzalez, J. P.; Pourrut, X.; Leroy, E. (2007). "Ebolavirus and Other Filoviruses". In Childs, J. E.; Mackenzie, J. S.; Richt, J. A. Wildlife and Emerging Zoonotic Diseases: The Biology, Circumstances and Consequences of Cross-Species Transmission. Current Topics in Microbiology and Immunology. 315. pp. 363-387. doi:10.1007/978-3-540 70962-6 15. ISBN 978-3-540-70961-9. PMID 17848072.

275. Mari Saez, A.; Weiss, S.; Nowak, K.; Lapeyre, V.; Zimmermann, F.; Dux, A.; Kuhl, H. S.; Kaba, M. et al. (30 December 2014). "Investigating the zoonotic origin of the West African Ebola epidemic". EMBO Molecular Medicine 7 (1): 17-23. doi:10.15252/emmm.201404792. PMID 25550396. PMC 4309665. "The severe Ebola virus disease epidemic occurring in West Africa likely stems from a single zoonotic transmission event involving a 2-year-old boy in Meliandou, Guinea, who might have been 
infected by hunting or playing with insectivorous free-tailed bats living in a nearby hollow tree"

276. Callaway, Ewen (2016). "Hunt for Ebola's wild hideout takes off as epidemic wanes". Nature (Nature News \& Comment) 529 (7585): 138139. doi:10.1038/529138a. PMID 26762436.

277. D'Odorico, Paolo; Hayman, David T. S.; Santini, Monia; Rulli, Maria Cristina (14 February 2017). "The nexus between forest fragmentation in Africa and Ebola virus disease outbreaks" (in en). Scientific Reports 7: 41613. doi:10.1038/srep41613. ISSN 2045-2322. PMID 28195145. PMC 5307336.

278. Nasi, Robert; Sheil, Douglas; Leendertz, Siv Aina; King, Shona; Suter, Jamison; Park, Douglas; Salim, Mohammad A.; Gaveau, David et al. (30 October 2017). "Recent loss of closed forests is associated with Ebola virus disease outbreaks" (in en). Scientific Reports 7(1): 14291. doi:10.1038/s41598-017-14727-9. ISSN 2045-2322. PMID 29085050. PMC 5662765.

279. CDC Telebriefing on Ebola outbreak in West Africa (Report). CDC. 28 July 2014. Retrieved 3 August 2014.

280. Osterholm, MT; Moore, KA; Kelley, NS; Brosseau, LM; Wong, G; Murphy, FA; Peters, CJ; LeDuc, JW et al. (19 February 2015). "Transmission of Ebola viruses: what we know and what we do not know". mBio 6 (2): e00137. doi:10.1128/mBio.00137-15. PMID 25698835. PMC 4358015.

281. Broadhurst, M. Jana; Brooks, Tim J. G.; Pollock, Nira R. (October 2016). "Diagnosis of Ebola Virus Disease: Past, Present, and Future". Clinical Microbiology Reviews 29 (4): 773-793. doi:10.1128/CMR.00003-16. PMID 27413095. PMC 5010747.

282. Bausch, Daniel G. (2017). "West Africa 2013 Ebola: From Virus Outbreak to Humanitarian Crisis". In Mühlberger, Elke; Hensley, Lisa L.; Towner, Jonathan S. Marburg- and Ebolaviruses: From Ecosystems to Molecules. Springer. p. 79. doi:10.1007/82_2017_69. ISBN 978-3-319-68948-7. Retrieved 14 January 2019.

283. Ebola media centre fact sheets (Report). WHO. Retrieved 21 September 2014.

284. Interim advice on the sexual transmission of the Ebola virus disease (Report). WHO. Retrieved 28 October 2016.

285. Deen, Gibrilla F.; Knust, Barbara; Broutet, Nathalie; Sesay, Foday R.; Formenty, Pierre; Ross, Christine; Thorson, Anna E.; Massaquoi, Thomas A. et al. (14 October 2015). "Ebola RNA Persistence in Semen of Ebola Virus Disease Survivors - Preliminary Report". New England Journal of Medicine 377 (15): 1428-1437. doi:10.1056/NEJMoa1511410. PMID 26465681. PMC 5798881.

286. "Why Testicles Are The Perfect Hiding Spot For Ebola". Popular Science. Retrieved 7 May 2015.

287. "Sex and masturbation may hamper Ebola eradication efforts". Reuters. 9 September 2015. Retrieved 14 September 2015.

288. Deen, Gibrilla F.; Broutet, Nathalie; Xu, Wenbo; Knust, Barbara; Sesay, Foday R.; McDonald, Suzanna L.R.; Ervin, Elizabeth; Marrinan, Jaclyn E. et al. (12 October 2017). "Ebola RNA Persistence in Semen of Ebola Virus Disease Survivors - Final Report". New England Journal of Medicine 377 (15): 1428-1437. doi:10.1056/NEJMoa1511410. PMID 26465681. PMC 5798881.

289. Broutet, Nathalie; Lofthouse, Clare; Formenty, Pierre; Thorson, Anna (2016). "Systematic review of the literature on viral persistence and sexual transmission from recovered Ebola survivors: evidence and recommendations". BMJ Open 6 (1): e008859. doi:10.1136/bmjopen2015-008859. PMID 26743699. PMC 4716240.

290. Salaam-Blyther, Tiaji (26 August 2014). "The 2014 Ebola Outbreak: International and U.S. Responses" (PDF). Retrieved 9 September 2014

291. Prevention of Ebola Hemorrhagic Fever (Report). CDC. Retrieved 28 October 2016

292. Ebola medics 'better trained in Sierra Leone than Spain' The Telegraph, by Fiona Govan, 11 October 2014

293. "Two Americans Stricken With Deadly Ebola Virus in Liberia". NBC News. 28 July 2014. Retrieved 2 August 2014.

294. "Doctors Without Borders: West Africa's Ebola Outbreak is Totally Out of Control". CTVNews. 20 June 2014. Retrieved 21 June 2014.

295. Unprecedented number of medical staff infected with Ebola (Report). WHO. 25 August 2014. Retrieved 27 August 2014.

296. Ladner, Jason T; Wiley, Michael R; Mate, Suzanne; Dudas, Gytis; Prieto, Karla; Lovett, Sean; Nagle, Elyse R; Beitzel, Brett et al. (2015). "Evolution and Spread of Ebola Virus in Liberia, 2014-2015". Cell Host \& Microbe 18 (6): 659-669. doi:10.1016/j.chom.2015.11.008. PMID 26651942. PMC 4711363.

297. Ebola response Roadmap (PDF) (Report). WHO. Retrieved 21 June 2016.

298. Contact tracing (Report). WHO. Retrieved 27 January 2019.

299. "The reason Ebola isn't being stopped". CNN. Retrieved 16 September 2014.
300. UN senior leaders outline needs for global Ebola response (Report). WHO. Retrieved 16 September 2014.

301. Fact sheet: U.S. Response to the Ebola Epidemic in West Africa (Report). The White House. Retrieved 2 November 2014

302. Ilesanmi, OS (2015). "Learning from the challenges of Ebola Virus Disease contact tracers in Sierra Leone, February, 2015". Pan Afr Med J 22 Suppl 1: 21. doi:10.11694/pamj.supp.2015.22.1.6537. PMID 26740849. PMC 4695526.

303. Ebola virus disease Fact sheet $N^{\circ} 103$ (Report). WHO. Retrieved 6 September 2014.

304. "Ebola -5 tips to avoid the deadly disease". Plan International. 6 September 2014. Retrieved 11 April 2015.

305. Diallo, Boubacar (29 March 2014). "Ebola en Guinée : I'ONG Plan Guinée craint une aggravation de l'épidemie" [Ebola in Guinea: the NGO Plan Guinea fears a worsening of the epidemic] (in French). Africa guinée. Retrieved 31 March 2014.

306. Ilesanmi, OS; Alele, FO (2015). "The effect of Ebola Virus Disease outbreak on hand washing among secondary school students in Ondo State Nigeria, October, 2014". Pan Afr Med J 22 Suppl 1: 24. doi:10.11694/pamj.supp.2015.22.1.6614. PMID 26740852. PMC 4695531.

307. "Encounters during the Ebola awareness campaign". PLAN International. Retrieved 2 November 2014.

308. "FAO Launches Ebola Awareness Campaign in West Africa". FAO. Retrieved 2 November 2014.

309. Ofeibea Quist-Arcton (6 August 2014). "Skeptics In Sierra Leone Doubt Ebola Virus Exists". NPR.

310. Anja Wolz (15 July 2014). "Fighting fear, denial and death on Ebola frontline". New Scientist. Retrieved 11 April 2015.

311. "Patients reported missing after Ebola clinic attacked in Liberia". Melbourne: The Age. 18 August 2014. Retrieved 18 August 2014

312. "Red Cross suspends Ebola operations in southeast Guinea after threats". Reuters. 2 July 2014. Retrieved 4 July 2014

313. "At least 8 Ebola aid workers reportedly killed 'in cold blood' by villagers in Guinea". Fox News. 19 September 2014. Retrieved 19 September 2014

314. Chan, M (20 August 2014). "Ebola Virus Disease in West Africa - No Early End to the Outbreak". The New England Journal of Medicine 371 (13): 1183-5. doi:10.1056/NEJMp1409859. PMID 25140856.

315. How to conduct safe and dignified burial of a patient who has died from suspected or confirmed Ebola virus disease (PDF) (Report). WHO. Retrieved 14 December 2014

316. Ebola situation report (Report). WHO. 21 January 2015. Retrieved 3 February 2015.

317. "Guinea's Grand Imam Pulls No Punches In His Ebola Message". NPR. 26 January 2015. Retrieved 3 February 2015.

318. "Hygiene practices have helped keep Ebola out of the classroom". UNICEF. 12 August 2015. Retrieved 14 August 2015.

319. Mosoka P. Fallah; Laura A. Skrip; Shai Gertler; Dan Yamin; Alison P. Galvani (31 December 2015). "Quantifying Poverty as a Driver of Ebola Transmission". PLOS Neglected Tropical Diseases 9 (12): e0004260. doi:10.1371/journal.pntd.0004260. PMID 26720278. PMC 4697799.

320. Buli, BG; Mayigane, LN; Oketta, JF; Soumouk, A; Sandouno, TE; Camara, B; Toure, MS; Conde, A (2015). "Misconceptions about Ebola seriously affect the prevention efforts: KAP related to Ebola prevention and treatment in Kouroussa Prefecture, Guinea". Pan Afr Med J 22 Suppl 1 11. doi:10.11694/pamj.supp.2015.22.1.6269. PMID 26740839. PMC 4695529.

321. Onyeonoro, UU; Ekpemiro, UC; Abali, C; Nwokeukwu, HI (2015). "Ebola epidemic - the Nigerian experience". Pan Afr Med J 22 Suppl 1: 17. doi:10.11694/pamj.supp.2015.22.1.6625. PMID 26740845. PMC 4695530

322. Wikipedia is already the world's 'Dr Google' - it's time for doctors and researchers to make it better Huffington Post. Conversation Global Editorial Group. Oct. 18, 2016. Downloaded Oct. 22, 2017.

323. Wikipedia Emerges as Trusted Internet Source for Ebola Information By Noam Cohen. Oct. 26. 2014. Downloaded Oct. 22, 2017.

324. McNeil, Donald G., Jr. (13 August 2014). "Using a Tactic Unseen in a Century, Countries Cordon Off Ebola-Racked Areas". The New York Times. Retrieved 14 August 2014.

325. "In Sierra Leone's Ebola hot zone: A series of reports". UN Office for the Coordination of Humanitarian Affairs. 2014-10-09. Retrieved 2 November 2014.

326. "Rally around West African communities to fight Ebola". The Seattle Times. Retrieved 2 November 2014

327. McCauley, Lauren (3 September 2014). "As Ebola Outbreak Surges, Health Officials Slam International 'Coalition of Inaction'". Common Dreams. Retrieved 7 September 2014 
328. Statement on the 8th meeting of the IHR Emergency Committee regarding the Ebola outbreak in West Africa (Report). WHO. Retrieved 9 June 2016

329. Removed: Ebola in Sierra Leone - Watch - Level 1, Practice Usual Precautions - Travel Health Notices - Travelers (Report). CDC. Retrieved 9 June 2016.

330. Interim U.S. Guidance for Monitoring and Movement of Persons with Potential Ebola Virus Exposure (Report). CDC. Retrieved 2 November 2014.

331. "MSF Protocols for Staff Returning from Ebola-Affected Countries". Doctors without Borders. Archived from the original on 2 November 2014. Retrieved 2 November 2014.

332. Public health recommendations for returning workers who are asymptomatic contacts of Ebola virus disease (PDF) (Report). Public Health England. 10 December 2014. Retrieved 11 April 2015.

333. "Ebola virus disease (EVD): Advice for returning travellers from countries/areas affected by EVD" (PDF). Public Health Ontario. Retrieved 2 November 2014

334. Treatment of Ebola (Report). CDC. 22 May 2018. Retrieved 23 January 2019.

335. "Emerging targets and novel approaches to Ebola virus prophylaxis and treatment". BioDrugs 27 (6): 565-83. December 2013. doi:10.1007/s40259-013-0046-1. PMID 23813435. PMC 3833964

336. Makiko Kitamura ( 8 June 2014). "Sierra Leone Is Epicenter of Ebola as Guinea Clinic Shut". Archived from the original on 24 October 2014. Retrieved 30 July 2014

337. Signs and Symptoms of Ebola Hemorrhagic Fever (Report). CDC. 30 May 2018. Retrieved 27 January 2019.

338. Magill, Alan (2013). Hunter's tropical medicine and emerging infectious diseases (9th ed.). New York: Saunders. p. 332. ISBN 978-1-4160-4390-4.

339. Schieffelin, John S; Shaffer, Jeffrey G; Goba, Augustine; Gbakie, Michael Gire, Stephen K; Colubri, Andres; Sealfon, Rachel S.G; Kanneh, Lansana et al. (29 October 2014). "Clinical Illness and Outcomes in Patients with Ebola in Sierra Leone". The New England Journal of Medicine 371 (22): 2092-2100. doi:10.1056/NEJMoa1411680. PMID 25353969. PMC 4318555

340. Angela L. Rasmussen, Atsushi Okumura, Martin T. Ferris, Richard Green, Friederike Feldmann, Sara M. Kelly, Dana P. Scott, David Safronetz, Elaine Haddock, Rachel LaCasse, Matthew J. Thomas1, Pavel Sova1, Victoria S. Carter, Jeffrey M. Weiss, Darla R. Miller, Ginger D. Shaw, Marcus J. Korth, Mark T. Heise, Ralph S. Baric, Fernando Pardo-Manue de Villena, Heinz Feldmann, Michael G. Katze, † (30 October 2014). "Host genetic diversity enables Ebola hemorrhagic fever pathogenesis and resistance". Science 346 (6212): 987-991. doi:10.1126/science.1259595. PMID 25359852. PMC 4241145

341. West, T. Eoin; von Saint André-von Arnim, Amélie (1 November 2014). "Clinical Presentation and Management of Severe Ebola Virus Disease". Annals of the American Thoracic Society 11 (9): 1341-1350. doi:10.1513/AnnalsATS.201410-481PS. ISSN 2329-6933. PMID 25369317.

342. Donald G. McNeil Jr. (1 January 2015). "Ebola Doctors Are Divided on IV Therapy in Africa". The New York Times. Retrieved 3 January 2015.

343. "IV Therapy for Ebola". Communities/Ebola Response. January 2015. Retrieved 7 January 2015

344. Ebola Virus Factsheet (Report). WHO. September 2014. Retrieved 28 October 2014

345. Bailes, Adam (22 October 2014). "Ebola Increases Threat to Sierra Leone Pregnancies". Voice of America. Retrieved 26 October 2014

346. "WHO Issues Guidance on Ebola Virus Disease in Pregnancy". Infection Control Today. Retrieved 21 September 2015.

347. "Baby and maternal deaths soar in Sierra Leone amid Ebola fears researchers". The Guardian. 2015-10-07. Retrieved 8 October 2015

348. Steve E Bellanemail; Juliet R C Pulliam; Jonathan Dushoff; Lauren Ancel Meyers (15 October 2015). "Ebola control: effect of asymptomatic infection and acquired immunity". The Lancet 384 (9953): 1499-1500. doi:10.1016/S0140-6736(14)61839-0. PMID 25390569. PMC 4829342. Retrieved 26 December 2015.

349. Clinical care for survivors of Ebola virus disease (PDF) (Report). WHO. 11 April 2016.

350. Carod-Artal FJ (2015). "Post-Ebolavirus disease syndrome: what do we know?". Expert Rev Anti Infect Ther 13 (10): 1185-7. doi:10.1586/14787210.2015.1079128. PMID 26293407.

351. A story of Ebola survival and return (Report). WHO. 14 November 2014 Retrieved 5 February 2015

352. "Mystery 'post-Ebola syndrome' emerges in West Africa". The Japan Times. 2013-05-10. Retrieved 21 May 2015.

353. "Ebola outbreak: Doctors warn of 'post-Ebola syndrome' among survivors in West Africa". ABC News (Australia). 2015-02-05. Retrieved 5 February 2015
354. "Thousands of Ebola survivors face severe pain, possible blindness". Yahoo! News. 8 August 2015. Retrieved 9 August 2015

355. Grady, Denise (7 May 2015). "After Nearly Claiming His Life, Ebola Lurked in a Doctor's Eye". The New York Times. Retrieved 6 March 2019.

356. Shantha, Jessica G.; Crozier, Ian; Yeh, Steven (November 2017). "An update on ocular complications of Ebola virus disease". Current Opinion in Ophthalmology 28 (6): 600-606. doi:10.1097/ICU.0000000000000426. ISSN 1531-7021. PMID 28872492. PMC 5988239.

357. Epstein, Lauren; Wong, Karen $\mathrm{K}_{i}$ Kallen, Alexander J; Uyeki, Timothy M (17 December 2015). "Post-Ebola Signs and Symptoms in U.S. Survivors". New England Journal of Medicine 373 (25): 2484-2486. doi:10.1056/NEJMc1506576. PMID 26672870.

358. Varkey, JB; Shantha, JG; Crozier, I; Kraft, CS; Lyon, GM; Mehta, AK; Kumar, G; Smith, JR et al. (Jun 2015). "Persistence of Ebola Virus in Ocular Fluid during Convalescence". New England Journal of Medicine 372 (25): 2423-2427. doi:10.1056/NEJMoa1500306. PMID 25950269. PMC 4547451.

359. Carod-Artal, FJ (13 August 2015). "Post-Ebolavirus disease syndrome: what do we know?". Expert Rev Anti Infect Ther 13 (10): 1185-7. doi:10.1586/14787210.2015.1079128. PMID 26293407.

360. "Ebola outbreak in West Africa 'out of control,' says MSF". Toronto Star. 2014. Retrieved 28 October 2016

361. "Liberia: Unheralded Fear - Ebola Pose Risks for Liberia Health Workers". FrontPage Africa. 19 June 2014. Retrieved 21 June 2014 - via AllAfrica.com

362. "MSF's new Ebola management centers already overwhelmed". Médecins Sans Frontières. Retrieved 11 April 2015.

363. Payne, Ed (12 September 2014). "West African health centers can't keep up with Ebola outbreak, WHO says". CNN Health. Retrieved 15 September 2014.

364. Ebola Response Roadmap Situation Report 18 September 2014 (PDF) (Report). WHO. 18 September 2014. Retrieved 19 September 2014.

365. "An Ebola treatment center". The Washington Post. Retrieved 1 October 2014

366. Guidance for Safe Handling of Human Remains of Ebola Patients in U. S. Hospitals and Mortuaries (Report). CDC. Retrieved 1 October 2014

367. "В Гвинее открылся построенный РУСАЛом медцентр по борьбе с вирусом Эбола". Sdelanounas. 17 January 2015. Retrieved 18 January 2015

368. "Russia opens Ebola center in Guinea". Russia Beyond The Headlines. 17 January 2015. Retrieved 18 January 2015.

369. "Sierra Leone: MSF opens maternity unit for pregnant women with Ebola". Médecins Sans Frontières. Retrieved 30 January 2015.

370. "Ebola: MSF opens new treatment centre in Kissy, Sierra Leone". Médecins Sans Frontières. 2015-01-08. Retrieved 11 April 2015.

371. Frequently asked questions on Ebola virus disease (Report). WHO. 8 August 2014. Retrieved 3 October 2014

372. "Woman saves three relatives from Ebola". CNN. 26 September 2014. Retrieved 14 October 2014

373. "Ebola Supplies Arrive in Liberia". Samaritan's Purse. 2 October 2014 Retrieved 3 October 2014

374. "In Order To Contain Ebola 9,000 Household Kits Arrive". Daily Observer. 25 September 2014. Archived from the original on 6 October 2014. Retrieved 4 October 2014.

375. "Are Hospitals Part of the Ebola Problem? Charity Wants New Strategy". NBC News. 15 September 2013. Retrieved 3 October 2014.

376. Bernstein, Lenny (22 September 2014). "New effort to fight Ebola in Liberia would move infected patients out of their homes". The Washington Post. Retrieved 2 October 2014

377. Youkee, Daniel; Brown, Colin S.; Lilburn, Paul; Shetty, Nandini; Brooks, Tim; Simpson, Andrew; Bentley, Neil; Lado, Marta et al. (21 December 2015). "Assessment of Environmental Contamination and Environmental Decontamination Practices within an Ebola Holding Unit, Freetown, Sierra Leone". PLOS ONE 10 (12): e0145167. doi:10.1371/journal.pone.0145167. ISSN 1932-6203. PMID 26692018. PMC 4687095

378. "How not to catch Ebola". BBC News. 7 October 2014. Retrieved 13 October 2014

379. "Ebola Protective Suits Are In Short Supply". NPR. 7 October 2014 Retrieved 13 October 2014

380. "Ebola Suit Maker Triples Output". ABC-News. 9 October 2014. Retrieved 13 October 2014.

381. K, Jayalakshmi (12 October 2014). "Ebola: Usaid Offers More Than Half a Million Pounds for Best Design for Protective Suit". International Business Times. Retrieved 28 October 2016.

382. "Innovating to Fight Ebola". The White House - Office of Science and Technology Policy. 29 October 2014. Retrieved 4 November 2014 
383. "Obama Tries A 'Throw Everything Against The Wall' Approach To Ebola". The Huffington Post. 31 October 2014. Retrieved 10 November 2014

384. Ravindranath, Mohana (24 November 2014). "USAID seeks help from 'maker movement' in Ebola outbreak". The Washington Post. Retrieved 26 November 2014.

385. "United States Announces Results of Grand Challenge to Fight Ebola" (Press release). USAID. 12 December 2014. Archived from the original on 9 January 2015. Retrieved 12 January 2015.

386. "Dreaming Up A Safer, Cooler PPE For Ebola Fighters". NPR. 17 December 2014. Retrieved 18 December 2014.

387. Mundasad, Smitha (2015-03-20). "'Ebola-proof' tablet device developed". BBC News. Retrieved 21 March 2015.

388. "Google develops Ebola-proof tablet for use by workers in Sierra Leone". IBNLive. Retrieved 23 March 2015.

389. William A. Fischer II; David J. Weber; David A. Wohl (November 1, 2015). "Personal Protective Equipment: Protecting Health Care Providers in an Ebola Outbreak". Clinical Therapeutics 37 (11): 2402-10. doi:10.1016/j.clinthera.2015.07.007. PMID 26452427. PMC 4661082. Retrieved 27 January 2016

390. Guidance on Personal Protective Equipment (PPE) To Be Used By Healthcare Workers during Management of Patients with Confirmed Ebola or Persons under Investigation (PUIs) for Ebola who are Clinically Unstable or Have Bleeding, Vomiting, or Diarrhea in U.S. Hospitals, Including Procedures for Donning and Doffing PPE (Report). CDC. Retrieved 27 January 2016.

391. Ebola (Ebola Virus Disease) (Report). CDC. Retrieved 28 October 2014.

392. Chan, Margaret (12 August 2014). WHO Director-General briefs Geneva UN missions on the Ebola outbreak (Report). WHO. Retrieved 14 August 2014.

393. "Ebola Situation Report" (PDF). 1 July 2015. Retrieved 4 July 2015.

394. "Liberia: top doctor becomes latest Ebola victim". The Guardian. 27 July 2014. Retrieved 28 July 2014.

395. Cham, Kemo (10 August 2014). "Another Sierra Leone doctor contracts Ebola". Africa Review. Retrieved 14 August 2014.

396. "Ebola-infected doctor in Sierra Leone, Sahr Rogers, dies". CBC News. 27 August 2014. Retrieved 28 August 2014

397. "Lagos records second Ebola case in doctor who treated victim: Nigerian health minister". Reuters. 4 August 2014. Retrieved 11 April 2015.

398. Vogel, Gretchen (28 August 2014). "Ebola's heavy toll on study authors". AAAS. Retrieved 12 January 2015.

399. McLaughlin, Eliott C. (10 December 2014). "Ebola fighters are Time's 'Person of the Year'". CNN World. Retrieved 10 December 2014.

400. Ebola Virus Disease in Health Care Workers - Guinea, 2014 (Report). CDC. Retrieved 27 January 2016.

401. Choi JH, Croyle MA; Croyle (December 2013). "Emerging targets and novel approaches to Ebola virus prophylaxis and treatment". BioDrugs 27 (6): 565-83. doi:10.1007/s40259-013-0046-1. PMID 23813435. PMC 3833964.

402. Clark DV, Jahrling PB, Lawler JV; Jahrling; Lawler (September 2012). "Clinical management of filovirus-infected patients". Viruses 4 (9): 166886. doi:10.3390/v4091668. PMID 23170178. PMC 3499825.

403. "Ebola: The race for drugs and vaccines". BBC. 2015-03-27.

404. Rush, James (13 November 2014). "Ebola virus: Clinical trials of three new treatments for disease to start in West Africa". London: The Independent. Retrieved 13 November 2014

405. "Genetic mutations in deadly Ebola virus appear to block antibody-based treatments". News-Medical.net. 14 September 2015. Retrieved 16 September 2015.

406. van Griensven, Johan; Edwards, Tansy; de Lamballerie, Xavier; Semple, Malcolm G.; Gallian, Pierre; Baize, Sylvain; Horby, Peter W.; Raoul, Hervé et al. (7 January 2016). "Evaluation of Convalescent Plasma for Ebola Virus Disease in Guinea". New England Journal of Medicine374 (1): 33-42. doi:10.1056/NEJMoa1511812. ISSN 0028-4793. PMID 26735992. PMC 5856332.

407. Oumar Faye; Alessio Andronico; Ousmane Faye; Henrik Salje; Pierre-Yves Boëlle; N'Faly Magassouba; Elhadj Ibrahima Bah; Lamine Koivogui et al. (1 December 2015). "Use of Viremia to Evaluate the Baseline Case Fatality Ratio of Ebola Virus Disease and Inform Treatment Studies: A Retrospective Cohort Study". PLOS Medicine 12 (12): e1001908. doi:10.1371/journal.pmed.1001908. PMID 26625118. PMC 4666644.

408. Butler, Declan (2014). "Ebola Experts Seek to Expand Testing". Nature 516 (7530): 154-155. doi:10.1038/516154a. PMID 25503213. Retrieved 11 December 2014.

409. H. Cai; J. W. Parks; T. A. Wall; M. A. Stott; A. Stambaugh; K. Alfson; A. Griffiths; R. A. Mathies et al. (25 September 2015). "Optofluidic analysis system for amplification-free, direct detection of Ebola infection".
Scientific Reports 5: 14494. doi:10.1038/srep14494. PMID 26404403. PMC 4585921.

410. "Chip-based technology allows fast, accurate Ebola detection". UPI. Retrieved 26 September 2015.

411. "Ebolavirus vaccines for humans and apes". Curr Opin Virol 2 (3): 324-29. June 2012. doi:10.1016/j.coviro.2012.04.003. PMID 22560007. PMC 3397659.

412. Grady, Denise (22 April 2015). "Ebola Drug Works Against West African Strain in Study of Monkeys". The New York Times.

413. Lai, Lilin; Davey, Richard; Beck, Allison; Xu, Yongxian; Suffredini, Anthony F.; Palmore, Tara; Kabbani, Sarah; Rogers, Susan et al. (5 March 2015). "Emergency Postexposure Vaccination With Vesicular Stomatitis Virus-Vectored Ebola Vaccine After Needlestick". JAMA 313 (12): 124955. doi:10.1001/jama.2015.1995. PMID 25742465. PMC 4874522.

414. Smart, Ben; Lucas, Liza (17 July 2015). "Results are in: Inhalable Ebola vaccine, Lyme disease". CNN.

415. Sridhar, S (2015). "Clinical development of Ebola vaccines". Ther Adv Vaccines 3 (5-6): 125-38. doi:10.1177/2051013615611017. PMID 26668751. PMC 4667768 .

416. "Vesicular Stomatitis Virus-Based Ebola Vaccines With Improved CrossProtective Efficacy". The Oxford Press. Retrieved 1 August 2015.

417. Chappell, Bill (31 July 2015). "New Ebola Vaccine Has ' 100 Percent' Effectiveness In Early Results". NPR. Retrieved 31 July 2015.

418. Ben Hirschler; Kate Kelland (20 January 2016). "Vaccines alliance signs $\$ 5$ million advance deal for Merck's Ebola shot". Reuters. Retrieved 27 January 2016.

419. "Final trial results confirm Ebola vaccine provides high protection against disease". December 23, 2006

420. "Democratic Republic of Congo: Ebola Virus Disease - External Situation Report 17: Declaration of End of Ebola Virus Disease Outbreak". ReliefWeb. Retrieved 26 July 2018.

421. Why the Ebola outbreak has been underestimated (Report). WHO. Retrieved 9 October 2014.

422. "West \& Central Africa - Information by Country". UNICEF. Retrieved 9 October 2014

423. Santermans, Eva; Robesyn, Emmanuel; Ganyani, Tapiwa; Sudre, Bertrand; Faes, Christel; Quinten, Chantal; Bortel, Wim Van; Haber, Tom et al. (15 January 2016). "Spatiotemporal Evolution of Ebola Virus Disease at Sub-National Level during the 2014 West Africa Epidemic: Model Scrutiny and Data Meagreness". PLOS ONE 11 (1): e0147172. doi:10.1371/journal.pone.0147172. ISSN 1932-6203. PMID 26771513. PMC 4714854.

424. Rambaut, Andrew (7 August 2014). "Case Fatality Rate for ebolavirus". Epidemic. Archived from the original on 29 August 2014. Retrieved 16 September 2014.

425. Ebola Response Roadmap Situation Report 2, 5 September 2014 (Report). WHO. Retrieved 18 September 2014.

426. Porta, M, ed. (2014). "Death rate". A Dictionary of Epidemiology (5th ed.). Oxford: Oxford University Press. p. 69. ISBN 978-0-19-939005-2.

427. "Basic Reproductive Rate (Ro)". University of Michigan. Archived from the original on 4 November 2014. Retrieved 16 September 2014.

428. Althaus, Christian L. (2014). "Estimating the Reproduction Number of Ebola Virus (EBOV) During the 2014 Outbreak in West Africa". PLoS Currents 6. doi:10.1371/currents.outbreaks.91afb5e0f279e7f29e7056095255b288. PMID 25642364. PMC 4169395.

429. Hunt, Allen G. (11 October 2014). "Exponential growth in Ebola outbreak since May 14, 2014". Complexity 20 (2): 8-11. doi:10.1002/cplx.21615.

430. WHO Virtual Press Conference on the third meeting of the International Health Regulations Emergency Committee regarding the 2014 Ebola outbreak in West Africa (PDF) (Report). WHO. Retrieved 5 November 2014

431. Kupferschmidt, Kai (2014-08-31). "Disease modelers project a rapidly rising toll from Ebola". Science (news). Retrieved 11 April 2015.

432. Nishiura, $\mathrm{H}_{i}$ Chowell, G (11 September 2014). "Early Transmission Dynamics of Ebola Virus Disease (EVD), West Africa, March to August 2014". Eurosurveillance (Eurosurveillance) 19 (36): 20894. doi:10.2807/1560-7917.ES2014.19.36.20894.

433. "Virologist: Fight against Ebola in Sierra Leone and Liberia is lost". Deutsche Welle. 11 September 2014. Retrieved 11 September 2014.

434. Szabo, Liz (22 September 2014). "Could the Ebola outbreak last forever?". USA Today. Retrieved 22 September 2014.

435. Farrar, Jeremy J. (23 September 2014). "The Ebola Emergency Immediate Action, Ongoing Strategy". New England Journal of Medicine 371 (16): 1545-1546. doi:10.1056/NEJMe1411471. PMID 25244185.

436. "OVERNIGHT HEALTH: Congress begs for attention on Ebola". The Hill. 2014-11-19. Retrieved 20 November 2014 
437. McNeil Jr, Donald G. (16 December 2014). "Fewer Ebola Cases Go Unreported Than Thought, Study Finds". The New York Times. Retrieved 11 April 2015.

438. "IMF says Ebola impacted West African nations may need economic assistance". Australian News.Net.

439. Jeremy Bowles (2016). "Ebola, jobs and economic activity in Liberia". Journal of Epidemiology and Community Health 70 (3): 271-277. doi:10.1136/jech-2015-205959. PMID 26438188. PMC 4789821. Retrieved 27 January 2016.

440. Stanturf, John A.; Goodrick, Scott L.; Jr, Melvin L. Warren; Charnley, Susan; Stegall, Christie M. (1 September 2015). "Social Vulnerability and Ebola Virus Disease in Rural Liberia". PLOS ONE 10 (9): e0137208. doi:10.1371/journal.pone.0137208. ISSN 1932-6203. PMID 26325519. PMC 4556488

441. Mark Anderson and agencies (22 August 2014). "Ebola: airlines cancel more flights to affected countries". The Guardian. Retrieved 25 August 2014

442. "Ebola Wreaks Economic Woe In West Africa". NPR. 17 July 2014. Retrieved 25 August 2014.

443. Lomax, Selma (20 August 2014). "Liberia: Ebola Outbreak Affects Agriculture in Lofa County". allAfrica.com. Retrieved 25 August 2014.

444. "First WHO worker infected by Ebola, DR Congo reports cases". Rappler.com. 15 August 2014. Retrieved 25 August 2014.

445. "Ebola threatens food security in West Africa: FAO". Reuters. 2 September 2014. Retrieved 3 September 2014

446. "Ebola Threatens Millions With Food Insecurity". VOA. Retrieved 19 December 2014

447. The Christian Science Monitor (2015-07-29). "How West Africa is ramping up food security after Ebola outbreak". Christian Science Monitor (The Christian Science Monitor). Retrieved 10 August 2015

448. "Ebola Virus Eats Into West Africa's Economic Growth". AFKInsider. 21 August 2014. Retrieved 25 August 2014.

449. "Impact of Ebola on e-commerce in Nigeria". CNBC Africa.

450. "Nigeria: Lagos Hotels Lose N8 Billion Over Ebola Outbreak". allAfrica.com. Retrieved 3 May 2015.

451. Brock, Joe (20 August 2014). "Ebola fears slowing tourist flow to Africa". Reuters. Retrieved 25 August 2014.

452. "Video: Impact of Ebola on e-commerce in Nigeria". CNBC Africa. Retrieved 16 December 2014

453. "Mixed grill for businesses as Ebola impacts economy". Vanguard News. 2014-09-15. Retrieved 16 December 2014.

454. Williams, Briohny (2015-01-07). "The Gambia's tourist industry reels from Ebola fallout". BBC News. Retrieved 13 January 2015.

455. Ghana News Agency. "Ebola scares tourist from Cape Coast Castle in 2014". spyghana.com. Retrieved 28 February 2015.

456. Tom Murphy (May 2015). "Tourists abandon Ghana despite its successes against Ebola". Humanosphere. Retrieved 10 May 2015.

457. "Kenya Tourism Board releases Sh140 million for tourism campaigns". Standard Digital News. 8 March 2015. Retrieved 8 March 2015.

458. "Tourism receipts down 3\%". The Standard. 2015-03-29. Retrieved 10 April 2015.

459. Sharon Gilbert-Rivett. "Africa Travel Week focuses on sustainable tourism". The M\&G Online. Retrieved 16 April 2015.

460. "UK employees leave Sierra Leone over Ebola threat". BBC News. 3 June 2014. Retrieved 25 August 2014.

461. "West Africa Ebola outbreak forces miners to lock down operations, delay projects". MINING.com. 10 August 2014. Retrieved 25 August 2014.

462. Jun Feng (December 2014). "Mining: African Minerals begins shutdown of Sierra Leone assets as Ebola effect hits". The Africa Report. Retrieved 21 December 2014

463. Clár Ní Chonghaile (2015-03-10). "Ebola crisis could force Sierra Leone to diversify economy away from mining - Clár Ní Chonghaile". The Guardian. Retrieved 27 March 2015.

464. "Ebola crisis: Oxfam calls for recovery Marshall Plan". BBC News. 2015 01-27. Retrieved 27 January 2015.

465. "Ebola-hit countries call for $\$ 8$ bn aid plan". newvision.co.ug. Retrieved 19 April 2015.

466. "IMF policies blamed for weak Ebola response". London: The Telegraph. 22 December 2014. Retrieved 23 December 2014

467. "Ghana, Business Advice, Jobs, News, Business Directory, Real Estate, Finance, Forms, Auto". Business Ghana. Retrieved 20 December 2014.

468. AFP. "IMF under pressure to cancel Ebola-hit countries' debts". Times LIVE. Retrieved 5 January 2015.
469. "IMF hopes for deal soon on debt forgiveness for Ebola countries". Reuters. 30 January 2015. Retrieved 3 February 2015.

470. "IMF increases support to Liberian economy following Ebola outbreak". Public Finance International. Retrieved 14 January 2016.

471. Titcomb, James (8 October 2014). "World Bank rings alarm over $f 20 \mathrm{bn}$ worst-case Ebola scenario". London: The Telegraph. Retrieved 8 October 2014

472. "New World Bank Group Study Forecasts Billions in Economic Loss". World Bank. Retrieved 8 October 2014.

473. "Liberia: Rebuilding Ebola-Hit Economy - Focus of World Bank Spring Event". allAfrica.com. Retrieved 16 April 2015

474. Alexandra Sifferlin (23 July 2015). "'We Are Not Prepared For Another Epidemic': World Bank Survey". Time. Retrieved 3 August 2015.

475. "World Bank Group Ebola Response Fact Sheet". World Bank. 15 December 2015. Retrieved 20 December 2015.

476. Flynn, Daniel (6 July 2015). "Ebola-stricken nations need $\$ 700$ million to rebuild healthcare". Reuters. Retrieved 8 July 2015.

477. "Ebola-Hit Countries Get Pledges of $\$ 3.4$ Billion to Rebuild - ABC News". web.archive.org. 11 July 2015. Retrieved 27 March 2019.

478. Betsy McKay (11 July 2015). "Donors Pledge \$3.4 Billion for Ebola Recovery Plan". The Wall Street Journal.

479. "United Nations News Centre". UN News Service Section. 29 September 2015. Retrieved 4 October 2015.

480. "China's investment in Africa down 43\%". The Irish Times. 24 November 2015. Retrieved 7 December 2015

481. "UPDATE 1-Liberia to slash spending 11 pct amid mining slowdown". Reuters. 25 January 2016. Retrieved 9 June 2016 - via Reuters.

482. "WHO says Ebola outbreak could strike 20,000 people". Reuters. 28 August 2014. Retrieved 28 August 2014.

483. Dopplick, Renée (29 April 2009). "Swine Flu: Legal Obligations and Consequences When the WHO Declares a "Public Health Emergency of International Concern"'". Inside Justice. Retrieved 6 June 2014.

484. "Ebola 'threat to world security'- UN Security Council". BBC News. 18 September 2014. Retrieved 18 September 2014.

485. "WHO warns Ebola response could cost \$1B". The Hill. 16 September 2014. Retrieved 16 September 2014

486. Ebola Response Roadmap Situation Report 15 October 2014 (PDF) (Report). WHO. p. 5. Retrieved 29 October 2014.

487. "Global Response". United Nations Mission for Ebola Emergency Response. Retrieved 29 October 2014.

488. Ebola response roadmap situation report 17 December 2014 (Report). WHO. Retrieved 19 December 2014

489. "Ebola". internationalsos.com. Retrieved 22 May 2015.

490. Bruce-Cunning, Nick. (18 May 2015). WHO Leader Outlines Changes in Response to Ebola Epidemic. The New York Times.

491. WHO Director-General addresses high-level conference on global health security (Report). WHO. Retrieved 28 October 2016.

492. "Aid workers ask where was WHO in Ebola outbreak". Reuters. 5 October 2014. Retrieved 5 October 2014.

493. "WHO chief promises transparency on Ebola failures". Associated Press. Retrieved 31 December 2014.

494. McVeigh, Tracy (18 October 2014). "Oxfam calls for troops in Africa as criticism of 'inadequate' Ebola response mounts". The Guardian. Retrieved 24 October 2014

495. "WHO leadership admits failings over Ebola, promises reform". Reuters. Retrieved 16 January 2016.

496. Sarah Boseley (2015-05-18). "Plan to reform WHO after Ebola to be unveiled by Angela Merkel". The Guardian. Retrieved 19 May 2015

497. "G7 underwhelms with Ebola response". Politico. 2015-06-08. Retrieved 17 June 2015.

498. Moon, Suerie; Sridhar, Devi; Pate, Muhammad A; Jha, Ashish K; Clinton, Chelsea; Delaunay, Sophie; Edwin, Valnora; Fallah, Mosoka et al. (2015). "Will Ebola change the game? Ten essential reforms before the next pandemic. The report of the Harvard-LSHTM Independent Panel on the Global Response to Ebola". The Lancet 386 (10009): 2204-2221. doi:10.1016/S0140-6736(15)00946-0. PMID 26615326. Retrieved 27 January 2016.

499. "Ebola crisis: WHO slammed by Harvard-convened panel over slow response". CNN. 23 November 2015. Retrieved 23 November 2015

500. "Ebola global response was 'too slow', say health experts". BBC News. 23 November 2015. Retrieved 23 November 2015. 